NBER WORKING PAPER SERIES

\title{
GANGS, LABOR MOBILITY AND DEVELOPMENT
}

\author{
Nikita Melnikov \\ Carlos Schmidt-Padilla \\ Maria Micaela Sviatschi \\ Working Paper 27832 \\ http://www.nber.org/papers/w27832
}

\section{NATIONAL BUREAU OF ECONOMIC RESEARCH \\ 1050 Massachusetts Avenue \\ Cambridge, MA 02138 \\ September 2020, Revised September 2022}

We thank Alicia Adsera, Cevat Giray Aksoy, Alberto Alesina, Sofia Amaral, Oriana Bandiera, Samuel Bazzi, Chris Blattman, Leah Boustan, Timothy Besley, Eli Berman, Ethan Bueno de Mesquita, Filipe Campante, Doris Chiang, Abby Córdova, Raúl Sanchez de la Sierra, Melissa Dell, Patricio Dominguez, John J. Donohue, Jennifer Doleac, Oeindrila Dube, Thad Dunning, Stefano Fiorin, Thomas Fujiwara, Tarek Ghani, Edward Glaeser, Jeff Grogger, Sergei Guriev, Gaurav Khanna, Asim Khwaja, Tom Kirchmaier, Ilyana Kuziemko, Horacio Larreguy, Benjamin Lessing, Nicola Limodio, Sarah Lowes, Stephen Machin, Atif Mian, Magne Mogstad, Chris Neilson, Sam Norris, Ben Olken, Daniel Ortega, Emily Owens, Rohini Pande, Paolo Pinotti, Oscar Pocasangre, Nishith Prakash, Stephen Redding, James Robinson, Mark Rosenzweig, Matteo Sandi, Jacob Shapiro, Santiago Tobón, Daniel Treisman, Oliver Vanden Eynde, Juan Vargas, Leonard Wantchekon, Austin Wright, Nathaniel Young, Ekaterina Zhuravskaya, Owen Zidar, Fabrizio Zilibotti, and the participants of seminars and conferences at the AEA, AL CAPONE, APPAM, APSA, Berkeley, Bocconi, CERP, Conference on the Economics of Crime and Justice, the EBRD, ESOC, Harvard, the IDB, ifo Institute, LSE, MIEDC, MIT, NBERSI, PSE, Princeton, Sciences Po, Stanford, University of Chicago, University of Connecticut, University of Munich, University of Passau, and Yale for helpful comments and suggestions. We also thank the International Crisis Group for helping us get access to certain parts of the data. Carlos Aguilar, Paulo Matos, Sarita Oré Quispe, Graciela Saca, and Édgar Sánchez-Cuevas provided excellent research assistance. The views expressed herein are those of the authors and do not necessarily reflect the views of the National Bureau of Economic Research.

NBER working papers are circulated for discussion and comment purposes. They have not been peer-reviewed or been subject to the review by the NBER Board of Directors that accompanies official NBER publications.

(C) 2020 by Nikita Melnikov, Carlos Schmidt-Padilla, and Maria Micaela Sviatschi. All rights reserved. Short sections of text, not to exceed two paragraphs, may be quoted without explicit permission provided that full credit, including $(\odot$ notice, is given to the source. 
Gangs, Labor Mobility and Development

Nikita Melnikov, Carlos Schmidt-Padilla, and Maria Micaela Sviatschi

NBER Working Paper No. 27832

September 2020, Revised September 2022

JEL No. O1,O17,O54

\begin{abstract} differential exposure to extortion and violence, or differences in public goods provision.

Nikita Melnikov

Rua da Holanda, 1

Nova School of Business and Economics

Carcavelos 2775-405

Portugal

nikita.melnikov@ novasbe.pt

Carlos Schmidt-Padilla

616 Serra Mall

Encina Hall

Stanford, CA 94305-6055

cschmidtpadilla@gmail.com

Maria Micaela Sviatschi

Department of Economics

Princeton University

128 Julis Romo Rabinowitz

Princeton, NJ 08544

and NBER

msviatschi@princeton.edu
\end{abstract}

We study how territorial control by criminal organizations affects economic development. We exploit a natural experiment in El Salvador, where the emergence of these criminal organizations was the consequence of an exogenous shift in American immigration policy that led to the deportation of gang leaders from the United States to El Salvador. Upon arrival, the gangs gained control over many urban areas and re-created a system of borders to protect their territory from outsiders. Using a spatial regression discontinuity design, we find that individuals in gangcontrolled neighborhoods have less material well-being, income, and education than individuals living only 50 meters away but outside of gang territory. None of these discontinuities existed before the arrival of the gangs. A key mechanism behind the results is that gangs restrict individuals' mobility, affecting their labor market options by preventing them from commuting to other parts of the city. The results are not determined by high rates of selective migration, 


\section{INTRODUCTION}

How does territorial control by non-state armed actors affect economic growth? On the one hand, it can impede the government from providing public goods, enforcing property rights and contracts, and preventing violence (Acemoglu et al., 2001; Michalopoulos and Papaioannou, 2013). On the other hand, if the government is weak and unable to control parts of its territory, non-state armed actors may take the role of the state and fulfill essential institutional functions, potentially enabling economic growth (Tilly, 1985; Olson, 1993; Bates et al., 2002; Ibáñez et al., 2019; De la Sierra, 2020) and competing for the hearts and minds of civilians (Ibáñez et al., 2019; De la Sierra, 2020; Blattman et al., 2022). ${ }^{1}$ Overall, the question of how and why territorial control by non-state armed actors affects development remains an open one.

In this paper, we study how territorial control by a specific type of non-state armed actorsnamely, criminal organizations-affects socioeconomic development. In urban areas in the developing world, millions of people live under some form of criminal governance (Lessing, 2021; Blattman et al., 2022). Criminal organizations mainly function in urban centers, often controlling certain parts of the city, while other parts are controlled by the state. In particular, this paper analyzes how territorial control by two of the world's most prolific gangs-MS-13 (Mara Salvatrucha) and 18th Street (Barrio 18) — affects socioeconomic development in El Salvador. ${ }^{2}$

We exploit a natural experiment that took place in El Salvador. Before 1996, El Salvador did not have any significant criminal organizations. However, in 1996, after a shift in American immigration policy, which made it easier to deport individuals with criminal backgrounds back to their country of origin, many Salvadoran migrants, who were members of California-based gangs (i.e., MS-13 and 18th Street), were deported back to El Salvador, where they re-established these gangs and quickly gained control over certain parts of the country. In order to protect their territory from outsiders, the gangs also re-created a system of borders and checkpoints that they used to establish territorial dominance in California (Nuño and Maguire, 2021), resulting in the division of urban areas between the gangs and the state.

To estimate the effects of gangs' territorial control, we use the boundaries of gang-controlled neighborhoods in El Salvador's capital, San Salvador, to perform a spatial regression discontinuity

\footnotetext{
${ }^{1}$ The origins of gangs in California and the Italian Mafia are also related to the inability of the state to regulate illegal activities and protect landowners' property rights (Gambetta, 1996; Bandiera, 2003; Skarbek, 2011; Acemoglu et al., 2019).

${ }^{2}$ Both MS-13 and 18th Street also have a major presence in Honduras, Guatemala, and parts of Italy, Mexico, Spain, and the United States. Moreover, similar criminal organizations are also present in many other countries (e.g., Brazil, Colombia, Jamaica, South Africa, etc.).
} 
design. These territorial demarcations formed soon after the arrival of the gang leaders in 1996 and roughly coincide with natural barriers, such as major roads and boulevards that were present at the time of the gangs' arrival. The outcome variables are measured using the 2007 census and our own geocoded survey, which we conducted in both gang and non-gang neighborhoods in 2019.

The results from the spatial regression discontinuity design indicate that residents of gangcontrolled neighborhoods in San Salvador have worse dwelling conditions, less income, and a lower probability of owning durable goods compared to individuals living just 50 meters away but outside of gang territory. They are also less likely to work in large firms. For instance, we find that residents of gang areas have \$350 lower monthly income (with the sample mean of \$625) compared to individuals living in neighboring non-gang locations and have a 12 percentage points lower probability of working in a firm with at least 100 employees. The results are highly robust to the choice of empirical specifications.

These differences in living standards did not exist before the arrival of the gang leaders from the United States. In particular, we replicate the regression discontinuity design with data from the 1992 census, showing that, prior to the emergence of the gangs, neighborhoods on both sides of the boundary of gang territory had similar socioeconomic and geographic characteristics, as well as similar levels of crime (and crime enforcement). These results are consistent with the fact that the boundaries of gang territory were formed not on the basis of pre-existing socioeconomic differences, but based on the availability of natural barriers, such major roads and boulevards, as we discuss in more detail in Section 4.3. We also show that the natural barriers are not associated with differences in socioeconomic conditions when they do not determine gang territorial control.

An important mechanism through which gangs affect socioeconomic development in the neighborhoods they control is related to restrictions on individuals' mobility. The gangs' long-term survival depends on their ability to secure the borders of their territory and prevent the police and rival gang members from arresting or killing them. Therefore, in order to maintain secure control over their territory, both MS-13 and 18th Street have instituted a system of checkpoints, not allowing individuals to freely enter or leave gang-controlled neighborhoods (ICG, 2018). This system of borders also provides the gangs with a readily available way of collecting extortion payments from all the individuals and firms that are allowed to cross the boundaries of their territory. ${ }^{3}$

Using the data from our geocoded survey, we perform a spatial regression discontinuity

\footnotetext{
${ }^{3}$ We also show how the safety that their territory provides allows the gangs to use it as a bridgehead from which they can conduct extortion raids in neighboring areas.
} 
design to document the presence of these restrictions on individuals' mobility. We show that residents of gang areas are 50 percentage points more likely to work in gang territory compared to individuals living only 50 meters away but on the other side of the boundary. They are also less likely to say that there is freedom of movement in the neighborhood where they live or to have been to places outside of San Salvador. These mobility restrictions affect labor market outcomes: residents of gang territory end up working in smaller firms and earning lower wages because they cannot commute to the areas where the largest and best-paying firms are located. In turn, local labor market conditions do not change at the boundaries of gang territory (i.e., there is no change in firm size, wages, profitability, or the number business establishments). However, residents of non-gang neighborhoods close to the boundaries are able to commute to parts of the city where the largest firms are located.

Another factor limiting socioeconomic development in gang-controlled neighborhoods is related to educational attainment. Using school census data, we show that the annual school dropout rate is 2 percentage points higher in gang territory than in non-gang areas. The resulting differences in educational attainment contribute to further widening the income gap between gang and non-gang territories.

We also examine other potential determinants of lower socioeconomic development in gangcontrolled neighborhoods but find that, in this context, they cannot explain the results. In particular, we demonstrate that individuals and firms on both sides of the boundary are equally exposed to extortion and other violent crimes. This result is explained by the fact that gang members are not subject to the same mobility restrictions as the other people living on their territory. As a result, they are able to extort individuals and businesses not only in the areas they control, but also in neighborhoods outside their immediate control. This result is fully consistent with the finding that local labor market conditions do not change at the boundaries of gang territory.

We also show the absence of a change in the homicide rate at the gang boundaries. This result is in line with the qualitative evidence highlighting that most of the violence occurs in disputed areas and not in neighborhoods that have been under gang control since the criminal deportees' arrival in the 1990s (Tita et al., 2005; Artsy, 2018), which are the focus of our analysis. In the context under consideration, violence is concentrated in areas right at the boundaries of gang territory, where it takes place because of outsiders attempting to enter those neighborhoods without permission. The paper's results are robust to excluding those areas.

Similarly, we find no differences in the availability and quality of public goods provision 
(i.e., schools, hospitals, etc.), which is consistent with the qualitative evidence suggesting that the government has been willing to provide public goods in gang areas in order not to ostracize the residents of those locations. ${ }^{4}$ In turn, because the gangs benefit from public goods provision in their neighborhoods, they have been willing to allow the government to provide (non-police-related) services in the areas they control. ${ }^{5}$ Finally, we show that the results are not driven by higher levels of unemployment (or informal employment) in gang-controlled neighborhoods and that selective migration of individuals across the boundary of gang territory can explain no more than $14 \%$ of the gap in socioeconomic development between the gang and non-gang neighborhoods.

Our paper is related to several strands of the existing literature. First, it contributes to the literature studying the origins and consequences of organized crime and other non-state armed actors (e.g., Gambetta, 1996; Frye and Zhuravskaya, 2000; Bandiera, 2003; Daniele and Marani, 2011; Acemoglu et al., 2013; Daniele and Geys, 2015; Buonanno et al., 2016; Dell, 2015; Pinotti, 2015; Daniele and Dipoppa, 2017; De Feo and De Luca, 2017; Acemoglu et al., 2019; Alesina et al., 2019; De la Sierra, 2020; Murphy and Rossi, 2020; Mirenda et al., 2022; Sviatschi, 2022a,b). Most of this literature has focused on violence, or the potential thereof, as the channel behind the effects of organized crime on politics, investment, migration, and other aspects of socioeconomic development. We complement this literature by presenting novel evidence on one specific aspect of criminal organizations that is increasingly prevalent in the developing world: territorial control in urban settings. By looking at urban areas where the territory is divided between the state and the gangs, we document a previously ignored mechanism through which criminal organizations affect socioeconomic development: restrictions to mobility. As Glaeser and Sims (2015) point out, little is known about the consequences of crime in the urbanized, developing world. In these contexts, because criminal organizations constantly face the potential for territorial challenges from both rival criminal groups and the state, it becomes necessary to implement stringent security measures to protect the borders of the neighborhoods they control (e.g., impose restrictions on individuals'

\footnotetext{
${ }^{4}$ In addition, the government and other political actors are motivated by electoral considerations: without providing public goods in gang-controlled neighborhoods, political parties would likely have been unable to campaign in those areas (e.g., see Córdova, 2019). This stems from the client-broker relationship between the political parties and the gangs, particularly during elections. In order to campaign in gang-controlled neighborhoods, political parties need to provide public goods in those areas.

${ }^{5}$ We also find that the gangs themselves provide a very limited amount of public services, the probability of which does not change at the boundaries of gang territory. This result may be different in other settings where non-state actors have the resources and incentives to co-opt the population under their control (e.g., Magaloni et al., 2020b; Blattman et al., 2022). In particular, in San Salvador, the gangs might not provide more public services in their territories themselves because the government has been willing to provide them. Salvadoran gangs are also very limited in their financial resources (Martínez et al., 2016), making it difficult for them to compete for hearts and minds. However, in settings where the government is not present (e.g., in rural areas) and criminal organizations have the resources to provide services to the public (e.g., drug cartels), territorial control by non-state actors may result in more public goods provision.
} 
mobility). As a result, residents of these neighborhoods end up having significantly worse labor market outcomes because of their inability to work in other parts of the city.

Second, our paper is related to the literature on criminal governance and the organizational structure of criminal enterprises (Levitt and Venkatesh, 2000; Skarbek, 2011; Carvalho and Soares, 2016; Ibáñez et al., 2019; Lessing and Willis, 2019; Magaloni et al., 2020a; Lessing, 2021; Blattman et al., 2022). A large part of the existing literature has shown how non-state armed actors emerge to fill the void left by the state and provide security and other public goods to the local population in exchange for political influence (e.g., Blattman and Miguel, 2010), taxation (e.g., Olson, 1993; De la Sierra, 2020), and the opportunity to conduct their illegal activities. Our paper analyzes how these relationships are altered in an urban context, where the proximity of the state, on the one hand, poses a threat to the gangs' territorial control but, on the other hand, allows the gangs to rely on the provision of most public goods by the government. ${ }^{6}$

Third, our paper contributes to the literature studying the causes and consequences of the formation of extractive institutions, which can have a long-lasting impact on socioeconomic development (e.g., Acemoglu et al., 2001, 2002; Dell, 2010; Michalopoulos and Papaioannou, 2013; Dell et al., 2018; Dell and Olken, 2020; Lowes and Montero, 2021). Specifically, it shows how the deportation of criminal leaders from the United States to El Salvador has resulted in them establishing two extortionary gangs that significantly limit socioeconomic development in the country. It also contributes to a long-standing debate on whether individual leaders-in this case, gang leaders-affect economic growth in developing countries (Jones and Olken, 2005).

Finally, our work is related to the literature analyzing the economic effects of barriers to geographical mobility. While the existing literature has focused on the effects of international borders (e.g., Clemons et al., 2008; McKenzie et al., 2010; Mergo, 2016; Calì and Miaari, 2018; Alsawady et al., 2022) and the absence of transportation infrastructure (e.g., Donaldson, 2018; Asher and Novosad, 2020), we complement it by showing how gang-imposed restrictions on individuals' freedom of movement can significantly affect socioeconomic development, even within an integrated metropolitan area and in the absence of direct transportation costs and legal borders. Given the global prevalence of similar intracountry barriers to mobility, our results provide important policy implications for many developing countries. In particular, non-state armed actors

\footnotetext{
${ }^{6}$ In particular, while the literature on stationary bandits would imply that armed actors have incentives in maximizing residents' incomes-including filling the voids of the state through some public goods provision-in order to maximize extortion rents in the territory they control (e.g., Olson, 1993; De la Sierra, 2020), we provide novel evidence that this incentive can be undermined in an urban context where labor market mobility is needed to maximize income.
} 
restrict individuals' freedom of movement in Brazil, Colombia, Guatemala, and Honduras (e.g., Ibáñez et al., 2019; Magaloni et al., 2020a), and many other countries experience alternative forms of mobility restrictions (e.g., see Walther et al., 2020).

The rest of this paper is structured as follows. Section 2 describes the rise of criminal groups in El Salvador and their organization. Section 3 describes the main data sources. Section 4 presents the identification strategy and the main results. Section 5 analyzes the mechanisms driving the results. Section 6 concludes.

\section{HISTORICAL BACKGROUND}

In this section, we present an overview of how MS-13 and 18th Street developed in Salvadoran migrant communities in the United States and how criminal capital was exported from these communities to El Salvador following a shift in American immigration policy in 1996. We then describe how, once in El Salvador, the gangs quickly established their criminal structures, began recruiting, and gained territorial control over certain neighborhoods, particularly in urban centers such as the capital, San Salvador. In particular, we provide qualitative evidence on how the boundaries of gang territory were formed soon after the arrival of the criminal deportees, based on the system of territorial control that the gangs had developed in the United States.

\subsection{The origins of MS-13 and 18 th Street}

Southern California, and especially Los Angeles, became home for thousands of Salvadorans fleeing the country's descent into civil war in the 1980s (Stanley, 1987). Lacking established network support, Salvadoran migrants lived in poor and overcrowded neighborhoods, often facing discrimination from other migrant groups (Brettell, 2011). In a typical family, both parents worked, often leaving the children without supervision (Savenije, 2009).

Left on their own and facing prejudice from other migrant groups and their gangs, some Salvadoran youth formed the precursors to MS-13, self-defense groups that were initially better known for petty crime, affinity to cannabis, and heavy metal rather than brutal violence, while others joined an existing Mexican gang, 18th Street (Dunn, 2007; Cruz, 2010; Martínez and Martínez, 2018). As membership grew across Salvadoran migrant communities, MS-13 and 18th Street became known to the local authorities, and some of their members were sent to prison, where they gained criminal capital and social connections that helped them solidify their structures (Womer 
and Bunker, 2010; Martínez and Martínez, 2018). By the mid-1980s, both MS-13 and 18th Street had developed independent identities, organizational structures revolving around territory-based cliques (clicas), and a fierce rivalry that continues to date (Ward, 2013).

One important characteristic of many gangs in Los Angeles in the 1980s has been the precise demarcation of their territory, which greatly contributed to their identity and development (Coughlin and Venkatesh, 2003). For example, during that time, graffiti became a popular way for the gangs to demarcate the territories under their control and to project authority over their rivals and the local population (Tita et al., 2005; Artsy, 2018). This demarcation had profound impacts on the mobility and decisions of individuals living in gang territories: "One of the really important things to think about is how the invisible borders ... add costs we often don't think about. If I'm a young person growing up in a particular neighborhood [in Los Angeles] and the closest movie theater or the closest shopping mall is claimed by a rival gang, ... I'm going to have to spend more time on a bus, put more gas in my car, to travel to other areas" (Artsy, 2018).

In an observational study of incarcerated MS-13 gang members in Los Angeles County, Nuño and Maguire (2021) highlight how "most MS-13 members are involved in cliques that claim certain turf or territory (96.3\%) and would be willing to use violence to defend it against others (92.6\%)," relying on graffiti and outposts to mark and control their territories. ${ }^{7}$ This facet of gang culture became the basis for the development and expansion of gang structures in El Salvador.

\subsection{American immigration policy and the emergence of gangs in El Salvador}

In 1996, in an effort to reduce crime in urban areas and address the surge in irregular migration into its territory, the United States passed the Illegal Immigration Reform and Immigration Responsibility Act (IIRIRA) (Chacón, 2009; Abrego et al., 2017). IIRIRA drastically increased immigration enforcement, creating expedited removal procedures, adding new grounds for deportation, and increasing the number of border patrol agents. In practice, for El Salvador, this shift in American immigration policy had a profound impact on the number of forced removals of its citizens from the United States, significantly increasing the number of repatriations following IIRIRA's passage in 1996. During the first wave of deportations, over 500 Salvadoran gang members were deported from the United States, leading to profound changes in Salvadoran communities as they

\footnotetext{
${ }^{7}$ The territorial identity is so important that, when MS-13 and 18th Street expanded to El Salvador, many of the cliques there adopted names that alluded to the locations where their gang leader-now repatriated to El Salvadorcommenced their illicit careers in the United States (e.g., Hollywood Locos Salvatruchos for the Hollywood area in Los Angeles).
} 
arrived (Sviatschi, 2022b).

Given that they did not have criminal records in El Salvador, the repatriated gang membersmany of whom were serving or had previously served sentences in the United States-gained their freedom after returning to their home country (Ward, 2013). In 1996, El Salvador was still recovering from the consequences of the civil war which ended in 1992, and the Salvadoran state did not have sufficient resources to prevent the gangs from expanding. The 1992 Peace Accords mandated the creation of a new police force-the National Civil Police (Policía Nacional Civil, PNC)—and at the time of the repatriations, the structure of the PNC was still being defined (e.g., there were no rural police units until 2004). As a result, the repatriated gang leaders exploited the low level of state capacity in El Salvador and expanded their operations to many urban areas.

As the vast majority of the repatriated MS-13 and 18th Street gang members had lived in the United States since a young age and lacked knowledge on their home country, most of them returned to their birth municipalities, relying on their family networks to re-settle in a new environment (DeCesare, 1998; Sviatschi, 2022b). Seeking social acceptance and status, the gang deportees banded together and tapped into local youth groups to replicate the gang structures they had in California. Even though only a few hundred gang members were repatriated from the United States in 1996, they quickly recruited new members from the local population. Many individuals were attracted by the sense of camaraderie and respect that the gangs offered, others sought more tangible material gains such as money and drugs (Cruz and Portillo Peña, 1998; Martínez and Martínez, 2018). Sviatschi (2022b), in particular, shows how, after the arrival of the gang deportees in 1996, El Salvador experienced an immediate increase in gang-related activities as MS-13 and 18th Street recruited adolescents to join their structures. According to the local authorities, by the end of 1996, at least 20 thousand people had joined the two gangs (Cruz and Portillo Peña, 1998).

\subsection{The formation of gang territory in El Salvador}

Taking advantage of the post-war environment and widespread destitution, both MS-13 and 18th Street quickly expanded their influence over many neighborhoods, particularly in urban areas such as the capital, San Salvador, "gain[ing] complete control of [certain] localities" (Zoethout, 2015). This rapid formation and enforcement of boundaries was possible due to four main factors: (i) the gangs' previous experience implementing a system of territorial control in California in the 1980s, (ii) the importance of territorial control both for the gangs' long-term survival and their identity, (iii) the gangs' ability to recruit new members from the local population, and (iv) El 
Salvador's low level of state capacity at the time of the criminal deportees' arrival.

The system of territorial control built upon the strategy that the gangs used in California: the demarcation was largely based on natural boundaries, splitting the city into small geographical confines known as cliques (Miguel Cruz, 2010). Back in El Salvador, the gang deportees also defined the boundaries of gang territory based on the presence of pre-existing natural barriers, such as major roads and boulevards (Tenorio, 2002; Vega, 2015), that made it difficult for the gangs to expand beyond them. While some of these natural barriers are only observed by the local population, this paper identifies and takes advantage of three major roads that largely determined the South-Western boundaries of gang territory (see Figure 1). These three roads are Bulevar Venezuela, 49 Avenida Sur, and Autopista Comalapa, all of which already existed in 1996 and all of which are wide multi-lane roads that make it difficult for the gangs to exert control over neighborhoods on both of their sides. In Subsection 4.3, we take advantage of these "natural boundaries" of gang territory to verify that the results of the regression discontinuity analysis are not determined by the potential endogeneity of some of the other boundaries. In Subsection 4.3, we also show (i) that the borders of gang-controlled neighborhoods were not formed as a result of pre-existing spatial differences in socioeconomic conditions or crime before the arrival of the criminal deportees and (ii) that the natural barriers that did not contribute to the formation of the gang boundaries do not affect socioeconomic outcomes.

Our conversations with the police and individuals living in gang areas suggest that, in San Salvador, the boundaries of gang territory have remained stable since they were formed soon after the arrival of the deportees. ${ }^{8,9}$ There have been attempts by the police to regain control over those locations, but, as of the time of this study, they have been unsuccessful. ${ }^{10,11}$ In part, those efforts have failed because the gangs have formed ties with the local population, cultivating a network of informants that allows them to elude capture (Cruz, 2010; Ward, 2013; Boerman and Golob, 2020).

The importance of the boundaries of gang territory has been widely documented. Inter-

\footnotetext{
${ }^{8}$ In Subsection 4.3 and Appendix Section C.1, we test the assumption that the boundaries have remained stable and discuss the empirical implications of potential inaccuracies in the maps of gang territory.

${ }^{9}$ Although there have been turf wars between MS-13 and 18th Street, they have focused on the original territories seized in the late 1990s. Outside San Salvador, certain municipalities did experience expansions of gangs' territorial control, especially in less urban areas that were not the focus of the first wave of the gangs' territorial expansion.

${ }^{10}$ In Subsection 4.4, we address the potential concern that, in order to prevent the gangs from expanding, the government has accumulated resources close to the boundary of gang territory. In particular, we show that the results are very similar if we exclude locations close to the boundary (see Table A20). We also check whether the government has been placing police stations close to the boundary of gang territory and find no evidence for this.

${ }^{11}$ In June 2019, the government launched the operation "Plan Territorial Control" (Plan Control Territorial), which seeks to regain control over gang territory. The launch of this plan and its name allude to the gravity of the situation and to the strength of the gangs: La Prensa Gráfica (accessed on October 5, 2019).
} 
national Crisis Group (ICG) describes the situation as follows: "In some areas, gangs have accumulated so much power that they have become de facto custodians of these localities, setting up road-blocks, supervising everyday life and imposing their own law" (ICG, 2017). In another interview, a resident of San Salvador is even more direct: "Do you see that place across the road? I could never get in there since it's the 18th Street gang's territory. If they see me in there, they might think I'm a spy [... ] and I could easily get killed" (ICG, 2018).

\subsection{Gang activity, restrictions on mobility, and public goods provision}

Once the gangs assert control over a particular neighborhood, they zealously protect it from outside influence. The main threat to the gangs' security comes from rival gang members and police informants entering their territory and arresting or assassinating them. A related threat is that residents of their territory will defect and provide information about the gangs' whereabouts and activities to the police or the rival gang. Therefore, to improve their security, both MS-13 and 18th Street rely on a system of checkpoints, requiring individuals attempting to enter or exit the area to show their identification cards, which have the residential address printed on them (ICG, 2018). To implement this policy, the gangs have junior gang members and collaborators (banderas) patrolling the boundaries of their territory (ICG, 2018; Boerman and Golob, 2020). ${ }^{12,13}$ This system of territorial control has existed in its current form since at least 1999 (Palma, 1999), supported by the gangs' ability to entice and coerce new banderas to join their criminal structures. Both MS-13 and 18th Street also use sophisticated techniques to track down potential defectors; many end up killed. ${ }^{14}$ Overall, gang-imposed restrictions on individuals' mobility are such a prominent issue in El Salvador that, in 2016, the criminal code was reformed to introduce the crime of "illegal restriction of freedom of movement", which penalizes "any person who, by violence, intimidation or threat to persons or property, prevents another from freely moving, entering, remaining or leaving any place in the territory of the Republic."

In addition to improving security, checkpoints also allow the gangs to collect extortion payments from those individuals and businesses that have been allowed to enter or exit their territory (e.g., distribution and transportation companies). Martínez (2016) describes the situation in the

\footnotetext{
${ }^{12}$ Often the banderas are barely 8 years old, which protects them from being arrested (ICG, 2018).

${ }^{13}$ Both MS-13 and 18th Street also sometimes stop public buses and check the identity cards of the people inside. If a passenger lives in a neighborhood controlled by a rival gang, they need to leave immediately or face the risk of being killed. For instance, see this report by the BBC (accessed on October 6, 2019).

${ }^{14}$ As a result, unless a resident of gang territory is confident that they will be able to avoid detection by the gangs, it would not be optimal for them to move to a different location. We provide a detailed discussion of the reasons preventing people from migrating out of gang territory in Section C.3 of the Appendix.
} 
following way: "One of the great advantages of having borders between rival gangs is imposing taxes. Everyone pays: companies that install cable television, the women that sell in the central markets, taxi drivers."15 More generally, both MS-13 and 18th Street rely on extortion as their main source of revenue and collect regular payments from individuals and businesses throughout San Salvador, including non-gang parts of the city (InSight Crime and CLALS, 2018). ${ }^{16}$

As a result of restrictions on their mobility, many residents of gang-controlled neighborhoods have poor labor market outcomes, being unable to work in locations outside of gang territory. However, as we show in Section 5.1, this does not happen due to a change in local labor market conditions at the boundaries of gang territory. Instead, people living in non-gang areas close to the boundary have better jobs due to their ability to commute to other parts of the city, where the largest and best-paying firms are located. The reason for the absence of a change in local labor market conditions is that, when it comes to collecting extortion payments (and other gang-related activities), gang members and their collaborators do not face restrictions on their mobility. As a result, as we show in Subsection 5.3, individuals and businesses in non-gang areas close to the boundary of gang territory have the same exposure to extortion and other gang-related crimes as residents of gang neighborhoods. Thus, another advantage of having territorial control over certain areas is that they provide a "bridgehead" from which the gangs can extort nearby locations that are not under their control. Then, after completing their mission, gang members can retreat back to the safety of their territory.

As the de facto authorities in their territories, gangs claim to be "providing a 'community service' by protecting locals from other criminals and corrupt police" (ICG, 2018). In reality, while such claims are not totally misleading, we find that, for two reasons, the gangs provide only a very limited amount of public services. First, unlike many other criminal organizations, such as drug cartels or the Italian Mafia, Salvadoran gangs are quite poor, with a rank-and-file gang member earning, at most, \$15 a week, half the minimum wage of an agricultural day laborer (Martínez et al., 2016). Therefore, the gangs do not have sufficient resources to invest in improving the economic conditions in the neighborhoods they control. The second reason why the gangs provide few public services is related to one of the peculiarities of the urban context in which the gangs and the state coexist. Given the government's proximity to gang territory, in the absence of mobility

\footnotetext{
${ }^{15}$ The fee is at least one to three dollars, a non-trivial expense for individuals whose average monthly income is approximately $\$ 300$, and needs to be paid to a bandera, who is monitoring the boundary of gang territory (ICG, 2018).

${ }^{16}$ According to the Salvadoran National Council of Small Businesses, $79 \%$ of businesses pay extortion to the gangs, including expensive restaurants and shopping malls (e.g., see this article by the Economist, accessed on May 8, 2020).
} 
restrictions, government workers have the capacity to provide public goods in the entire city and not only in areas controlled by the state. Moreover, the government has had at least two reasons to continue investing in infrastructure and social and educational programs in gang-controlled neighborhoods. First, if the government were to stop providing public goods in gang territory, its legitimacy in the eyes of the local population would likely be undermined, increasing support for the gangs (Zoethout, 2015). Second, such a move could be costly for incumbent politicians: "gangs serve as intermediaries between political parties and residents in controlled neighborhoods [...] offer[ing] political candidates what no other broker or intermediary can provide-the use of coercive violence to sway elections in their favor" (Córdova, 2019). Thus, not providing social programs in gang areas could significantly reduce politicians' reelection prospects, in addition to potentially endangering their lives. ${ }^{17}$

In turn, the gangs have been willing to allow non-police-related government workers to enter their territory and provide public services, both because gang members directly benefit from their availability and because government investment indirectly contributes to higher revenues from extortion. For example, the construction and repair of roads in gang-controlled neighborhoods has allowed the gangs to collect more extortion payments from trucks and transportation companies passing through their territory (ICG, 2017).

\section{DATA}

In this section, we document the primary sources of data drawn upon in this study. Further clarifications about the data, as well as a description of the ancillary data sources, can be found in Section A of the Appendix. Table A1 in the Appendix presents the summary statistics of the outcome variables used in the analysis.

Gang boundaries.-In 2015, a local newspaper-El Diario de Hoy (EDH)—published the map that is utilized in this study (see Figure 1), which delimited the locations controlled by MS-13 and 18th Street in San Salvador. EDH based its report on information and cartography from the Ministry of Justice and Public Security and the PNC. The newspaper further validated the map of gang boundaries by confirming that the gang-controlled neighborhoods on the map are also the places where its distribution network had periodic encounters with gang members. We have also independently verified the accuracy of the map published by EDH. ${ }^{18}$ Moreover, in Subsection C.1

\footnotetext{
${ }^{17}$ For an in-depth look at how gangs use their political power, see El Faro (accessed on October 6, 2019).

${ }^{18}$ In particular, we contacted the PNC and were confidentially shown their 2018 map of gang-controlled areas, which
} 
of the Appendix, we present evidence on how the boundaries of gang territory had remained stable between the time they were formed soon after the emergence of the gangs and 2015 when EDH published the map of gang areas.

1992 and 2007 population and household censuses.-The General Directorate of Statistics and Censuses (Dirección General de Estadísticas y Censos, DIGESTYC) provided us with de-identified microdata for the 1992 and 2007 censuses. The data cover the socioeconomic characteristics of all the country's households and individuals, including-but not limited to-educational attainment and material ownership (e.g., having a car, a TV, etc.). Both censuses also recorded the characteristics of all the dwellings in El Salvador. Notably, the data for these variables were not self-reported by the respondents but recorded by the enumerators based on their observations. For most outcome variables, both censuses had the exact same wording of the questions. Hence, the data are directly comparable across censal exercises. ${ }^{19}$

1992 and 2007 censal cartography.-DIGESTYC also provided us with maps of the census tracts (segmentos censales) for both the 1992 and the 2007 censuses. Each census tract represents a very small area with a fixed geographic perimeter. In 2007, the average census tract in our sample included 131 households and 473 individuals. The fact that the census tracts are quite small allows us to accurately measure their location, which we estimate by using the geographic coordinates of their centroids. In addition, because of the difficulty with attributing treatment status, we exclude 27 census tracts (4\% of the census tracts in San Salvador), which have the centroid outside of gang neighborhoods, but at least $25 \%$ of their territory is controlled by the gangs. Finally, we limit our analysis to census tracts located within 420 meters of the boundary of gang territory because after that, there are gaps in the distribution of observations both inside and outside of gang-controlled areas. ${ }^{20}$

2019 suroey. - To document the mechanisms through which gangs affect socioeconomic development, in 2019, we conducted our own geocoded survey in San Salvador. To be consistent with the census data, the survey was conducted in areas within 420 meters of the boundary of gang territory. The survey was designed to be representative by 30-meters bins, denoting the dis-

was almost exactly the same as the map published by EDH. For confidentiality reasons, we are not able to use or present the 2018 map in the paper.

${ }^{19}$ The notable exception are questions related to technologies that were not widely available in 1992 (e.g., access to the internet). These questions were only asked in the 2007 census.

${ }^{20}$ For instance, in the 1992 data, there are no census tracts that are located 430 meters away from the boundary outside of gang territory (i.e., such census tracts do not exist). We have verified that the results are fully robust to not limiting the sample to observations within 420 meters of the boundary. 
tance to the boundary of gang territory (separately for each side of the boundary). ${ }^{21}$ It consisted of in-person interviews and contained questions related to individuals' mobility, employment, income, satisfaction with public goods provision, and the role of formal (i.e., government) and informal institutions in resolving problems in the neighborhood. However, it should be noted that, for security reasons, we were unable to directly ask individuals questions related to gang activity.

Extortion.-The data on the extortion payments made by firms and individuals in San Salvador to the gangs come from the following three sources: (i) a geocoded survey of small and medium-sized enterprises conducted by a local think tank in 2015; (ii) geocoded confidential internal records on all the extortion payments that a large Salvadoran distribution firm made to the gangs in 2012-2019; and (iii) our own geocoded telephone survey that we conducted in San Salvador in 2020. We provide more information on these data sources in the Appendix.

Annual school censuses.- The annual school census data were obtained from the Ministry of Education and cover the period from 2005 to 2017. These censuses include annual information on the number of students enrolled in each grade at the beginning of the year and the number of students that graduated from each grade, allowing us to calculate the dropout rate for each schoolyear in our sample. Some of the schools also participated in the Program for Adult Literacy and Education, the purpose of which was to provide school-level education for adults without a school degree. For these schools, we additionally calculate the dropout rate among adults.

Homicides and robberies. - The data on gang-related homicides come from the PNC and cover the period from 2003 to 2014 . For each observation, we obtained information about the time and day it occurred, whether the perpetrator was a member of a gang, and the address of occurrence. Using these addresses, we manually geocoded the data to obtain the latitude and longitude of the homicides carried out by gang members. The PNC also shared with us the data on gang-related homicides in 2000, but these data are available only at the municipality level.

The data on robberies come from the Metropolitan Planning Office for San Salvador (Oficina de Planficación del Área Metropolitana de San Salvador, OPAMSS). They cover the period from 2014 to 2015 and contain information on the time, date, and location of all robberies, including their latitude and longitude.

Incarceration data.-The data on incarcerations come from the General Directorate of Prisons

\footnotetext{
${ }^{21}$ The choice to make the survey representative by 30-meters bins was made because, as described in Subsection 4.1 , 30 meters is the average value of the optimal bandwidth for the variables from the 2007 census, which is estimated using the procedures suggested in Imbens and Kalyanaraman (2012) and Calonico et al. (2014, 2018, 2020). The full details of the survey's sampling procedure can be found in the Appendix.
} 
(Dirección General de Centros Penales, DGCP) and represent the universe of all individuals who have been incarcerated in the country since the mid-1980s. The records contain information about the crimes the individual has committed, the date of incarceration, the municipality and department of birth, and the latest known address. For inmates who entered prison before 1997 and whose latest known address is in San Salvador municipality (4,726 individuals), we manually geocoded the residential addresses to obtain the precise geocoordinates used in the analyses. Given that geocoded crime data prior to 2003 are unavailable, the inmates' residential addresses represent the best measure of criminal activity in the pre-treatment period.

\section{GANG CONTROL AND SOCIOECONOMIC DEVELOPMENT}

To estimate the effects of gangs' territorial control on socioeconomic development, we begin with performing a spatial regression discontinuity design, focusing on San Salvador municipality.

\subsection{Empirical strategy: Regression discontinuity}

We begin by estimating the effect of gangs' territorial control on socioeconomic development using data from the 2007 census. For each census tract, we calculate the distance from its centroid to the boundary of gang territory (in tens of meters) and perform a spatial regression discontinuity design, using this distance as the forcing variable (Specification 1):

$$
y_{i c}=\alpha_{0}+\alpha_{1} \text { distance }_{c}+\alpha_{2} \text { gang territory } \text { distance }_{c}+\alpha_{3} \text { gang territory }_{c}+\varepsilon_{i c}
$$

where, depending on the specification, $i$ denotes individuals, dwellings, or households, and $c$ denotes census tracts. gang territory is a dummy variable for whether the location is controlled by the gangs, distance represents the distance to the boundary of gang territory, and $y$-the outcome variable of interest. As a baseline, standard errors in parentheses are clustered by 30-meter bins denoting the distance to the boundary of gang territory, separately for locations inside and outside of gang territory. This size of the bins comes from estimating the optimal bandwidth for each of the outcome variables from the 2007 census, following Imbens and Kalyanaraman (2012) and Calonico et al. (2014, 2018, 2020): 30 meters is the average value of the optimal bandwidth for the variables from the 2007 census. ${ }^{22}$ The assumption behind this way of clustering the standard errors

\footnotetext{
${ }^{22}$ We have verified that the results are fully robust to using smaller or larger distance bins to cluster the standard errors, and we illustrate this fact for the main outcome variables in Figures A15 and A16. In Table A8 in the Appendix,
} 
is that the correlation between the error terms primarily depends on the distance to the boundary of gang territory (e.g., because of differential spillovers of gang activity). The alternative possibility is that the error terms are correlated only within neighboring areas. Therefore, in the main regression tables, when it is possible, we also report Conley standard errors (in brackets), which allow for spatial correlation within a 100 meter radius. ${ }^{23}$ Throughout the paper, the significance of the results remains the same regardless of which standard errors are used.

The coefficient of interest is $\alpha_{3}$, which represents the effect of living in a gang-controlled neighborhood. The two assumptions for interpreting this effect as causal are as follows. First, nongang areas close to the boundary of gang territory should provide the appropriate counterfactual for socioeconomic development in the absence of gang control. In Subsection 4.3, we validate this assumption by showing that, before the arrival of the gangs, locations on both sides of the current boundaries of gang territory had similar geographic and socioeconomic characteristics as well as the same number of incarcerated individuals. We also identify places, where the locations of the boundaries were determined by the presence of natural barriers that prevented the gangs from expanding further. We then use these natural boundaries of gang territory to verify that our results are not driven by the potential endogeneity of some of the other boundaries. The second assumption is that residents of gang territory did not selectively migrate from those areas to neighboring locations in the control group. Subsection 4.3 and Appendix Subsection C.2 provide a detailed discussion of this assumption, showing that selective migration can explain no more than $14 \%$ of the socioeconomic gaps between gang and non-gang areas.

\subsection{Main results}

Table 1 presents the results of estimating Specification (1) using the data from the 2007 census. It shows that, after experiencing gang rule, individuals living in gang-controlled neighborhoods have significantly worse dwelling conditions, lower levels of education, and are less wealthy than their peers on the other side of the boundary. For instance, residents of gang territory are esti-

we also show that the estimates do not change if we divide the map of San Salvador into $300 \times 300$ meter grid cells and include fixed effects for each of the grid cells in the regression specification. Thus, the results are not driven by the comparison of gang and non-gang areas in different parts of the city. The results are also robust to performing a two-dimensional regression discontinuity design in latitude and longitude instead of distance to the boundary of gang territory (Table A9 in the Appendix).

${ }^{23}$ It is not possible to report Conley standard errors for certain outcome variables. For instance, in some regressions, the unit of observation is a 10-meter bin, denoting the distance to the boundary of gang territory (e.g., the number of schools per square kilometer). In these cases, by definition, each unit of observation consists of locations in different parts of San Salvador. Moreover, because the 10-meter bins are visually represented by concentric curves around the boundary of gang territory, each unit of observation has the same centroid. 
mated to have 21 percentage points lower probability of owning a car, 15 percentage points lower probability of having a high school degree, and 5 percentage points lower probability of their houses' walls being made of concrete than individuals living less than 50 meters away but not under the control of gangs. ${ }^{24}$ The results for the other measures of socioeconomic development present the same pattern.

Figure 2 illustrates the findings from Table 1 for the first principal components of the dwelling, household, and individual characteristics. The vertical axis represents the average value of the outcomes variables; the horizontal axis-distance (in meters) to the boundary of gang territory. Areas to the left of the dashed line are located outside of gang territory; areas to the right are controlled by the gangs. For all the outcome variables, there is a clear discontinuity at the boundary of gangcontrolled neighborhoods. ${ }^{25}$

Overall, the results suggest that gangs have had a significant negative effect on socioeconomic development in the neighborhoods they control. To estimate the total monetary cost of this effect, we consider a variable that potentially aggregates all the effects of living under gang control into one-household income, the data for which come from the 2019 survey. Figure A4 presents the regression discontinuity plot for this variable. The results suggest that residents of gang neighborhoods earn approximately \$350 less each month compared to residents of non-gang areas. Given that the average income in our sample is $\$ 625$, this discontinuity implies a reduction in income of more than 50\%. Table A5 in the Appendix presents the regression estimates for household income and the other socioeconomic characteristics from the 2019 survey.

\subsection{Addressing identification challenges}

In this subsection, we analyze the assumptions that need to be satisfied for the estimates in Table 1 to represent the causal effect of gang control on socio-economic development. In particular, we show that, before the arrival of the deportees, areas on both sides of the boundary of gang territory had similar geographic and socioeconomic characteristics as well as the same number of incarcerated individuals. We also show that boundaries have been stable over the years and that the results are robust to using natural boundaries and are not driven by selective migration across the boundaries of gang territory.

\footnotetext{
${ }^{24}$ In the individual-level regressions, the sample consists of the entire population. The results are very similar if, instead, we perform the analysis for the adult population.

${ }^{25}$ In the Appendix, we illustrate the results for all the other outcome variables from Table 1. Figure A1 presents the results for the dwelling characteristics, Figure A2-for the household characteristics, and Figure A3-for the individual characteristics.
} 
Conditions before the arrival of the gangs. - To ensure that non-gang areas close to the boundary of gang territory are the appropriate counterfactual for gang-controlled neighborhoods, we check that, before the arrival of the gangs, those locations did not have any pre-existing differences in geography, socioeconomic development, or crime.

First, we estimate Specification (1) for potentially important neighborhood characteristics (e.g., elevation, access to the waterways, road density, etc.) and the socioeconomic characteristics from the 1992 census (e.g., dwelling conditions, having a TV, etc.). ${ }^{26}$ Columns 1-24 of Table 2 present the results. There are no discontinuities in any of the variables, confirming the notion that, initially, the locations on opposite sides of the boundary were not different from one another. Figures A6-A9 in the Appendix illustrate the results for the neighborhood, dwelling, household, and individual characteristics, respectively.

Next, we estimate Specification (1) for the level of crime prior to the arrival of the gangs, measured by the number of people incarcerated in different parts of the city. We use incarceration records from San Salvador's prisons and geocode the residential addresses of the 4,726 individuals who have been incarcerated prior to $1997 .{ }^{27}$ Then, we calculate the number of incarcerations per square kilometer for each 10-meter bin, denoting the distance to the boundary of gang territory (separately for each side of the boundary). ${ }^{28}$ Columns 25-30 of Table 2 present the results of estimating Specification (1) for different types of crimes, showing that locations on both sides of the boundary had similar levels of crime prior to the arrival of the gangs. ${ }^{29}$

Overall, we find that before 1996, gang and non-gang locations had similar levels of socioeconomic development and crime, allowing us to conclude that non-gang areas close to the boundary are the appropriate counterfactual for gang neighborhoods in the absence of gangs.

\footnotetext{
${ }^{26}$ Some neighborhood characteristics (e.g., elevation or access to the waterways) are time-invariant. Other neighborhood characteristics potentially change over time. For all the variables except for road density, we use the data either from before the arrival of the gangs or soon after their arrival. For road density, the data reflect 2020 infrastructure, making the pre-treatment balance test for this variable valid only under the assumption that road density is practically time-invariant. However, given the difficulty of constructing new roads in the center of a large city, this assumption is likely to be satisfied. A detailed description of the data is available in the Appendix.

${ }^{27}$ Given that geocoded crime data are unavailable prior to 2003, incarceration records provide the best measure of criminal activity in the pre-treatment period. In addition, the fact that incarceration records contain the exact last residence address for each individual allows us to analyze whether there were more criminals in gang-controlled neighborhoods relative to non-gang neighborhoods.

${ }^{28}$ We perform the calculation in the following way. First, we divide the map of San Salvador into zones, denoting every 10 meters of distance from the boundary of gang territory, separately for gang and non-gang areas (e.g., all nongang locations that are within 10 meters of the boundary of gang territory, all non-gang locations that are 10-20 meters away from gang territory, etc.). Then, for each of the zones, we calculate the number of geocoded addresses located in it and divide that number by the area of the zone. The same procedure is used for other outcome variables with the same unit of analysis.

${ }^{29}$ As we explain in footnote 23 , in these specifications, it is impossible to report Conley standard errors. The reason is that the unit of analysis includes areas from different parts of the city.
} 
Boundaries of gang territory from geographical barriers. - To address any remaining concerns regarding the potential endogeneity of the boundaries, we perform the following analysis. We identify three major multi-lane roads-Bulevar Venezuela, 49 Avenida Sur, and Autopista Comalapawhich together created more than 45 kilometers of natural barriers that largely determined the South-Western boundaries of gang territory. ${ }^{30}$ Table 3 reports the results of estimating Specification (1) that, instead of the actual boundaries of gang territory, uses these three roads to predict the location of the borders. The results remain highly significant, demonstrating that they are not driven by the potential endogeneity of some of the boundaries of gang territory.

We also perform a placebo analysis, in which we use major roads that do not define the boundaries of gang territory, to ensure that these geographical barriers did not affect socioeconomic development through factors unrelated to the gang boundaries. The analysis focuses on a series of consecutive roads, ranging from Paseo General Escalón in the West to Avenida Independencia in the East, that split San Salvador into two similarly-sized parts (see Appendix Figure A11). We then estimate whether the level of socioeconomic development changes at the placebo boundary. ${ }^{31}$ Appendix Table A4 presents the results, confirming the notion that major roads do not affect development outcomes through factors unrelated to the gang boundaries.

Stability of the boundaries of gang territory.-A potential concern is that the boundaries of gang territory may not have remained stable between the time they were formed soon after the emergence of the gangs and 2015 when EDH published the map of gang territory. If the EDH map does not accurately reflect which neighborhoods were controlled by the gangs in 2007, the estimates in Table 1 would be biased towards zero (i.e., against finding an effect). ${ }^{32}$ Thus, the results in Table 1

\footnotetext{
${ }^{30}$ In reality, many more of the boundaries of gang territory are determined by the presence of natural barriers. However, many of these barriers are only observed by the local population.

${ }^{31}$ Specifically, we estimate the regression specification defined below, where north is a dummy variable for a census tract being to the north of the placebo boundary. We allow the overall level of socioeconomic development as well as the effect of distance to the placebo boundary to be different in gang and non-gang areas, but we have verified that the results are similar (although less precise) if we consider a regression specification that does not allow this. The coefficient of interest is $\psi_{6}$, which estimates the change in socioeconomic conditions at the placebo boundary. Since there are relatively more gang-controlled census tracts close to the placebo boundary, we expand the sample to include census tracts that are located within 1500 meters of the placebo boundary. Thus, we ensure that the results are not driven only by gang-controlled neighborhoods.

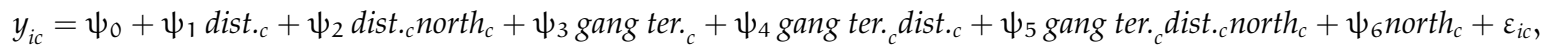

${ }^{32}$ For instance, if, in reality, the gangs controlled more neighborhoods than suggested by the map, then, under the assumption that the gangs have a homogeneous effect on socioeconomic development in all the areas they control, that would underestimate the living conditions in the control group. That would lead to the difference in living conditions between the gang and non-gang areas being underestimated. Similarly, if the gangs actually controlled fewer neighborhoods than suggested by the map, then the living conditions in the treatment group would be overestimated, which would also lead to a smaller difference between the treatment and control groups. Thus, the estimates presented in
} 
should be interpreted as the lower bound of the effects of gang control.

Nevertheless, in Subsection C.1 of the Appendix, we demonstrate that the boundaries of gang territory have remained stable since the time they were formed soon after the arrival of the gangs. Specifically, we exploit the fact that most gang-related homicides take place precisely at the boundaries of gang territory because of people attempting to enter or leave gang-controlled neighborhoods without permission. ${ }^{33}$ As a result, by showing that, throughout the years, gangrelated homicides consistently take place right at the boundaries from the EDH map, we are able to confirm the validity of that map and to demonstrate the stability of those boundaries.

The fact that the boundaries of gang territory have remained stable since the arrival of the gangs has also allowed us to address the concern that over the years the government had managed to selectively regain control over the wealthiest gang-controlled neighborhoods, generating the observed discontinuities in socio-economic development. If this had been the case, we would have observed more gang-related homicides outside of the current boundaries of gang territory in earlier years, which Appendix Section C.1 demonstrates to be not the case. ${ }^{34}$ Finally, in the next subsection we also show that results are robust to excluding observations close to the boundary, providing further evidence that effects are not driven by changes in the stability of the boundary.

Selective migration: In-sample migration.-Another assumption that needs to be satisfied for our estimates to be interpreted as causal is that there has been no selective migration of individuals across the regression discontinuity threshold. Selective migration can affect our results in two ways. The first one is what we will refer to as in-sample migration: individuals moving from a neighborhood on one side of the boundary to an area on the other side of the boundary, while remaining in the municipality of San Salvador and, consequently, in our sample. This type of migration would be a direct threat to identification because it would imply that individuals can manipulate their treatment status. The second one is what we will refer to as out-of-sample migration: individuals moving from a location in San Salvador to a different municipality in El Salvador or abroad. This type of migration does not invalidate the identification strategy, but it changes the interpretation of the mechanism through which the gangs affect local socioeconomic conditions (i.e., that gang control makes wealthy educated individuals leave San Salvador).

\footnotetext{
Table 1 should be interpreted as the lower bound of the effect of gang control.

${ }^{33}$ This phenomenon has also been documented in gang neighborhoods in Los Angeles in the 1970s-1990s, where most of the violence took place right at the entrance to these neighborhoods (Artsy, 2018).

${ }^{34}$ These findings help to also rule out that urban development in the control group could be moving gang boundaries over the years and thus squeezing gang control to some distance, generating a discontinuity in development around the space which coincides with the gang border. Moreover, in Table 7, we show no differences on the number of businesses such as malls, grocery stores or restaurants across the boundary.
} 
In this subsection, we consider the direct threat to identification that comes from in-sample migration. We provide a detailed discussion of the extent of out-of-sample migration in Appendix Subsection C.2. In particular, we estimate the extent of selective out-of-sample migration by considering how the household's wealth affects the probability of a family member migrating abroad in 1997-2007. Our results suggest that selective out-of-sample migration can explain no more than $14 \%$ of the gaps in socioeconomic development from Table 1.

To show that in-sample migration is not driving our findings, we take advantage of the 2019 survey, where, among other questions, we asked individuals whether they have lived in the same neighborhood their entire life. $77 \%$ of respondents answered in the affirmative. This information allows us to compare the results for the full sample and for the subsample of respondents for whom we know the ex-ante treatment status (i.e., that they lived in the location before the arrival of the gangs). In the absence of in-sample migration, the two sets of results would be quite similar, whereas, if the results are determined by in-sample migration, the discontinuities would only appear in the full sample.

Notably, this exercise also allows us to determine that the results are not driven by selective in-migration: wealthy and educated newcomers choosing to settle in non-gang parts of San Salvador. By restricting the sample to individuals who have lived in the same neighborhood their entire life, by definition, we exclude all newcomers.

When the sample is limited to individuals who have always lived in the same neighborhood, the results of the regression discontinuity analysis practically do not change. Figure A10 illustrates this fact by showing the two regression discontinuity plots for household income. The left-hand side of the figure presents the results for the full sample, the right-hand side-for the subsample of never-movers. The two plots are quite similar, suggesting that the results are not driven by selective in-sample migration. Table A5 in the Appendix presents the regression estimates for the socioeconomic characteristics from the 2019 survey, both for the full sample and for the sample of never-movers, and Figure A13 illustrates these results. ${ }^{35}$

Difference-in-differences analysis using nighttime light density. - We also demonstrate the absence

\footnotetext{
${ }^{35}$ In the 2007 census, individuals were also asked whether they have lived in the same municipality their entire life. Since individuals who answered in the affirmative could still have moved within the municipality, this question is less precise at determining the ex-ante treatment status of the respondents. However, coincidentally, the share of population that has always lived in San Salvador municipality is equal to 77\%, the same number as the share of population that has always lived in the same neighborhood according to the 2019 survey. Thus, it appears that, in this context, individuals primarily move across municipalities and not within the same municipality. Under this assumption, we estimate Specification (1) for the variables from the 2007 census for the subsample individuals who have always lived in the same municipality. Appendix Table A6 presents the results, which are very similar to those presented in Table 1, confirming that in-sample migration is not likely to be driving the results.
} 
of pre-trends in socioeconomic development between gang and non-gang areas. Specifically, to show that the two types of locations did not experience different rates of economic growth before the arrival of the gangs, we perform a difference-in-differences analysis using nighttime light density (or luminosity) — which recent studies have found to be a good proxy for development at the local level (Chen and Nordhaus, 2011; Henderson et al., 2012) - as the outcome variable. ${ }^{36}$ We exploit two sources of variation: the timing of the deportation of the gang leaders from the United States-which led to the emergence of the gangs in El Salvador-and the geographic differences in exposure to organised crime. ${ }^{37}$ Our hypothesis is that prior to 1996 - the year of the first wave of deportations from the United States-locations that would later have different levels of gang activity experienced similar rates of economic development. At the same time, after 1996, we expect to see higher rates of growth in areas with no gang presence. Further details and the exact regression specifications are provided in Appendix B.

The results of the difference-in-differences analysis are summarized in Figure A12. ${ }^{38}$ It shows that, before 1996, places with and without future gang presence experienced the same growth in nighttime light density, confirming the absence of pre-trends between the two areas. However, after the emergence of the gangs in 1996-1997, areas with gang presence experienced significantly lower luminosity growth.

\subsection{Robustness checks}

Excluding areas close to the boundary of gang territory.-Appendix Table A7 presents the results of "doughnut hole" regression discontinuity design in which we estimate Specification (1), excluding observations within 100 meters of the regression discontinuity cutoff. ${ }^{39}$ This analysis serves the following three purposes. First, it demonstrates that our results are robust to potential inaccuracies in the location of the boundaries of gang territory and are not driven by outlier areas near the boundary. Second, given that most gang-related homicides take place close to the boundaries of gang territory because of people attempting to enter or leave those neighborhoods without per-

\footnotetext{
${ }^{36}$ The additional benefit of using nighttime light density data is that, since they are collected via satellite from space, unlike survey data, they cannot be selectively under-reported or misreported.

${ }^{37}$ The nighttime light density data have the resolution of approximately $1 \mathrm{~km} \times 1 \mathrm{~km}$, which is not sufficiently precise to perform the analysis using the boundaries of gang neighborhoods in San Salvador. Instead, the analysis is performed for all of El Salvador, with gang presence being measured based on the availability of gang-related homicides. Further details are presented in Appendix B.

${ }^{38}$ The regression estimates can be found in Tables A2 and A3.

${ }^{39}$ The results are robust to the choice of alternate "doughnut hole" cutoff. For instance, the results are very similar if we exclude observations within 50 meters or 150 meters of the boundary of gang territory.
} 
mission, the "doughnut hole" regression discontinuity design allows us to verify that the results in Table 1 are not driven by high levels of violence close to the boundary. Third, this analysis addresses the potential concern that, in an attempt to prevent the gangs from expanding their territorial control, the government has been investing resources in non-gang areas close to the boundary. ${ }^{40}$ The results in Appendix Table A7 are very similar to those in Table 1.

Controlling for $300 \times 300$ meter fixed effects. - A potential concern is that the results in Table 1 might be driven by the comparison of gang-controlled locations in one part of San Salvador to non-gang areas in a different part of the city. To ensure that the identifying variation comes from comparing neighboring census tracts, we perform the following analysis. We divide the map of San Salvador municipality into $300 \times 300$ meter grid cells and record the grid cell corresponding to each census tract. ${ }^{41}$ On average, each grid cell contains 1.5 census tracts. We then estimate Specification (1), including fixed effects for each of the grid cells. Thus, we rely on the within-grid-cell variation in treatment status to measure the effect of gang control on socioeconomic development. Table A8 presents the results, which are very similar to those in Table 1.

Regression discontinuity using latitude and longitude.-We show that the results are robust to using a two-dimensional regression discontinuity design with latitude and longitude as the forcing variables. Specifically, we estimate Specification (1), replacing distance to the boundary of gang territory with latitude and longitude, normalized to have the mean of zero. The results are presented in Table A9 in the Appendix.

Excluding $10 \%$ of the top observations from non-gang areas. - We show that the results are not driven by a small number of wealthy individuals living outside of gang territory. In particular, we exclude $10 \%$ of the observations from non-gang areas that have the highest values of the first principal component of the dwelling, household, and individual characteristics. ${ }^{42}$ As reported in Appendix Table A10, the estimates remain statistically significant.

Different bandwidth.-We also show that our findings are robust to alternative choices of bandwidth by presenting the regression discontinuity plots for larger and smaller distance bins

\footnotetext{
${ }^{40}$ We analyze this concern in more details in Subsections 5.1 and 5.4, where we show that local labor market conditions and public goods provision does not change at the boundary of gang territory.

${ }^{41}$ We use the coordinates of the census tracts' centroids to assign the census tracts to the grid cells.

${ }^{42}$ To implement this analysis, we rank households and individuals according to the first principal components of the household and individual characteristics, respectively. We then exclude $10 \%$ of the observations with the highest values of the first principal component. When more than $10 \%$ of the observations had the values of the first principal component higher or equal to the value of the 90th percentile, we exclude a random subset of observations for which the first principal component is exactly equal to the 90th percentile (all observations with higher values are always excluded). The estimates do not depend on the subsample of observations that are excluded. In particular, we perform 1,000 iterations of this procedure and for each variable report the most conservative results.
} 
than in the baseline specification. Figure A15 in the Appendix illustrates the results for the first principal components of the dwelling, household, and individual characteristics, using 60 meter distance bins; Figure A16 illustrates the same results using 20 meter bins. ${ }^{43}$

Under-reporting of wealth. - A potential concern is that residents of gang-controlled neighborhoods might be more likely to under-report their wealth compared to residents of non-gang areas (e.g., to evade taxation by the gangs). We address this concern in the following three ways, showing that the results are not driven by selective under-reporting of wealth.

First, as the census data on the dwelling characteristics were recorded by the enumerators based on what they observed and not self-reported by the respondents, the discontinuities in the dwelling characteristics cannot be determined by selective under-reporting of wealth.

Second, we consider a non-self-reported measure of individuals' wealth: rent paid for housing. Specifically, we analyze the data on the housing offers in various parts of San Salvador, which provides us with the landlords' assessment of individuals' ability to pay. ${ }^{44}$ We then estimate Specification (1) with monthly housing rent as the outcome variable, additionally controlling for observable housing characteristics (i.e., the number of rooms, the number of bathrooms, square meters, etc.). Table A11 and Figure A17 in the Appendix present the results. They suggest that housing rent is approximately $\$ 200$ lower in gang-controlled locations, confirming the notion that residents of those areas are poorer than residents of non-gang neighborhoods.

Finally, in Appendix Section B, we validate the results of the regression discontinuity design by performing a difference-in-differences analysis using nighttime light density data, which are collected via satellite from space and cannot be under-reported. We show that, after 1996, areas that became exposed to gang activity experienced significantly lower growth in luminosity, confirming the notion that the gangs have had a negative effect on socioeconomic development.

Estimating the effects separately for MS-13 and 18th Street.-We show that MS-13 and 18th Street have had similar effects on socioeconomic development in the neighborhoods they control. In particular, we estimate Specification (1), replacing the dummy for gang territory with dummies for the areas controlled by MS-13 and for the areas controlled by 18th Street. The results are presented in Table A12 in the Appendix and are very similar for both gangs.

\footnotetext{
${ }^{43}$ For brevity, we only report the results for the first principal components of the dwelling, household, and individual characteristics. The results for the other variables from Table 1 are similar.

${ }^{44}$ The data were scraped from OLX (accessed on April 8, 2020). It should be noted that we cannot observe whether a particular property was rented out or not. However, after two months, the vast majority of the offers were no longer available. It should also be noted that some of the cheapest properties may be rented out on the informal market and not appear on OLX. If there are more such properties in gang-controlled neighborhoods, our estimates provide a lower bound on the actual effects of gang control.
} 
Excluding gang areas within 150 meters of the rival gang.- -To show that the negative effects on socioeconomic development are present not only in areas where the two gangs, which have an adversarial relationship, are particularly close to each other, we estimate Specification (1), excluding gang-controlled neighborhoods that are located within 150 meters of the rival gang's territory. ${ }^{45}$ The results are presented in Table A13 in the Appendix.

"Islands" of gang territory.-As shown in Figure 1, most gang-controlled neighborhoods are located close to each other in the east of the city. However, there are also smaller "islands" of gang territory in other parts of San Salvador. We check whether those "islands" have been affected in the same way as the main gang areas. Specifically, we estimate Specification (1), replacing the dummy for gang territory with dummies for the "islands" and for the rest of gang territory. Appendix Table A14 presents the results, suggesting that both types of gangs territory are similarly affected.

Estimating the effects separately for men and women.-We verify that both male and female residents of gang territory have been affected by estimating Specification (1) for the individual characteristics from the 2007 census separately for women and men. The results are presented in Appendix Table A15.

\section{MECHANISMS}

In this section, we explore the mechanisms behind the negative effects of gangs' territorial control on development outcomes. In particular, we provide novel evidence on how gang-imposed mobility restrictions affect individuals' labor market choices by preventing them from commuting to areas outside of gang territory, where the largest and best-paying firms are located. We also show that the differences in educational attainment between gang and non-gang areas can be explained by higher dropout rates in gang-controlled neighborhoods. Finally, we investigate alternative mechanisms and find that the regression discontinuity results cannot be explained by differences in crime (including homicides, extortion, and robberies), the composition of firms at the boundary of gang territory, or public goods provision.

In Appendix Section C.2, we show that the results are not determined by selective migration of individuals out of gang territory. Specifically, we estimate the rates of selective out-ofsample migration by considering the relationship between household wealth and the probability of a family member migrating abroad in 1997-2007, finding that selective migration accounts for no more than $14 \%$ of the gaps in socioeconomic development between gang and non-gang areas.

\footnotetext{
${ }^{45}$ The results are robust to changing this cutoff.
} 
In Appendix Section C.4, we also demonstrate that the regression discontinuity results cannot be explained by differences in the occupational structure, such as unemployment, informal employment, hours worked, and willingness to work.

\subsection{Restrictions on mobility}

The presence of mobility restrictions.-To document the presence of restrictions on individuals' mobility, we estimate Specification (1) for the mobility questions from the 2019 survey. Table 4 presents the results. The estimates in Column 1 suggest that the share of population working in gang-controlled neighborhoods dramatically increases by almost 50 percentage points (from $5.7 \%$ to $55.2 \%$ ) at the boundary of gang territory. Residents of gang territory are also more likely to work in the same neighborhood where they live and are less likely to have been to places outside of San Salvador: the share of individuals who have ever been to the beach or visited Santa Ana department, which are both 30-60 kilometers away, discontinuously decreases at the boundary of gang territory. ${ }^{46}$ Finally, residents of gang areas acknowledge that there are restrictions on their mobility, as evidenced by them being significantly less likely to say that there is freedom of movement in the location where they live. ${ }^{47}$

Figure 3 presents the regression discontinuity plots for the two most important variables in Table 4: the share of people working in gang territory and the share of people who think there is freedom of movement in the area where they live.

Labor market consequences.-The consequence of these mobility restrictions is that residents of gang neighborhoods often cannot work outside of gang territory, being forced to accept lowpaying jobs in small firms because of their inability to commute to other parts of the city, where the largest firms are located. ${ }^{48}$ To demonstrate these negative effects of restrictions on individuals' mobility, we compare the labor market outcomes for residents of gang areas who are able to work

\footnotetext{
${ }^{46}$ In Appendix Table A16, we demonstrate that the results in Table 4 are not driven by the fact that poorer and less educated individuals have lower levels of mobility. In particular, for the questions in Columns 3-6 of Table 4, we show that the results are robust to controlling for individuals' income and education. We do not perform the same analysis for the questions in Columns 1 and 2 of Table 4 because the individuals' work location directly affects their income, meaning that those regressions would be affected by reverse causality.

${ }^{47}$ This last result is likely to underestimate the share of residents of gang territory who experience mobility restrictions for two reasons. First, some of the respondents may have interpreted the question in the narrow sense of whether they are free to move within their neighborhood of residence (i.e., within gang territory), not as the ability to freely go to any part of the city. Second, the team that administered the survey reported that residents of gang areas were sometimes wary of admitting to experiencing restrictions on their mobility out of fear of retaliation from the gangs.

${ }^{48}$ This fact is confirmed by anecdotal evidence from the field. For instance, while we were conducting the survey in San Salvador, one of the respondents from a gang neighborhood told us how he used to have a good job at a gas station but had to give it up because the gas station was located close to the territory of a rival gang. The gang that controls his neighborhood told the man that he should find a different job or "face the consequences".
} 
outside of gang territory and those who are not. Table 5 presents the results, showing that, while, on average, residents of gang-controlled neighborhoods earn less income and work in smaller firms than individuals from non-gang locations, these gaps are significantly smaller for residents of gang territory who are able to work outside gang areas. In particular, we find that the latter are as likely to work in firms with 100 or more employees as individuals living outside of gang locations. They also have a 40\% smaller gap in household income compared to other residents of gang territory. ${ }^{49}$

Since working outside of gang territory is not likely to be entirely random, the results in Table 5 should be interpreted with caution. For instance, one potential concern is that if bettereducated residents of gang-controlled neighborhoods are more likely to get permission to work in non-gang areas, that could result in an overestimation of the premium of working outside of gang territory. However, the data suggest that there is considerable variation in the probability of working outside of gang territory across education levels, which is consistent with the notion that luck plays an important role in determining whether a resident of gang territory is allowed to work in a non-gang location (e.g., gang leaders in certain neighborhoods may be less willing than others to enforce restrictions on mobility; individuals might find ways to circumvent the gangs' restrictions). Moreover, as shown in Table 5, the results are robust to controlling for individuals' level of education, suggesting that they are not driven by more educated residents of gang-controlled neighborhoods being more likely to work in non-gang locations. ${ }^{50}$

Another potential concern is that instead of reflecting the costs of restrictions on individuals' mobility, the results in Table 5 represent the unwillingness of large firms to hire residents of gangcontrolled areas out of fear that they might be affiliated with the gangs. We address this concern in the following two ways. First, we note that, as shown in Column 6 of Table 4, residents of gang territory acknowledge that they do not have freedom of movement. Second, we exploit the fact that men are significantly more likely than women to be affiliated with the gangs. As a result, if the differences in employment outcomes between residents of gang and non-gang areas are driven

\footnotetext{
${ }^{49}$ Note that household income is defined at the level of the household, whereas the individuals' work locations are defined at the individual level. Thus, if multiple people in the household work outside of gang territory, the effect on income is likely to be larger. For instance, if two people in the household work in non-gang areas, the gap in income would be $2 \times 167.64 / 430 \approx 80 \%$ smaller, which is close to the results for the probability of working in a firm with 100 or more employees. Another potential reason why working outside of gang territory does not fully explain the gap in earnings is that income today depends on past work experience, and residents of gang territory are less likely to have had good jobs in the past.

${ }^{50}$ The results are also robust to including dummies for all the years of education. In all the specifications in Table 5, we also control for whether an individual is currently employed. In the survey, unemployed individuals were asked to describe their most recent work experience. Thus, some unemployed respondents said that their most recent job was in a gang-controlled neighborhood, while others previously worked outside of gang territory.
} 
by discrimination and not restrictions on mobility, then the gaps in labor market performance should be smaller for women living in gang-controlled neighborhoods than for men. The results in Appendix Table A17 show that this is not the case. Thus, even if some employers discriminate against job applicants from gang neighborhoods, that effect is not the main determinant of the differences in employment outcomes between gang and non-gang areas.

Overall, our findings suggest that gang-imposed restrictions on mobility are a major factor affecting individuals' labor market outcomes.

Connection to local labor market conditions.-Importantly, the differences in labor market outcomes are not caused by a change in local labor market conditions at the boundary of gang territory. To analyze this question, we use data from the 2005 economic census, which reported the location, revenue, costs, and profits of all (formal and informal) business establishments in El Salvador. Using these data, we estimate Specification (1) to analyze whether there is a change in these variables at the boundary of gang territory. Columns 1-3 of Appendix Table A18 report the results, showing that the firms' profits, revenue, and costs are the same on both sides of the boundary. In Column 4 , we also demonstrate that the number of business establishments per square kilometer similarly does not change at the boundary of gang territory. This result is further verified in Columns 5-8, using data from Google Maps instead of the 2005 economic census.

How can the absence of a change in local labor market conditions be consistent with the result that residents of gang neighborhoods have significantly lower income than people living only 50 meters away but outside of gang territory? The answer lies in the fact that the largest and most profitable firms have chosen to locate themselves further away from gang-controlled areas. Thus, while the size and profitability of business establishments do not change at the boundary of gang territory, there is a gradual increase in these variables for firms further away from gang neighborhoods. For instance, if one considers business establishments located within 50 meters of the boundary, the average profits of firms from non-gang areas are $7.8 \%$ lower than the average profits of firms from gang territory (the difference is not statistically significant). However, business establishments that are located more than 500 meters outside of gang neighborhoods have profits that are $90.3 \%$ higher than those in gang areas close to the boundary.

This result has two important implications. First, it highlights the importance of gangimposed restrictions on individuals' mobility. Since non-gang neighborhoods close to the boundary do not have large, well-paying firms, residents of those areas have higher incomes not because of the differences in local labor market conditions but because of their ability to commute to other 
parts of the city where the largest firms are located. Second, it suggests that non-gang areas close to the boundary might still be partially affected by the proximity of the gangs (Subsection 5.3 provides a detailed analysis of this result). In this case, the regression discontinuity estimates would represent the lower bound for the effects of gangs on development outcomes.

Why do mobility restrictions exist? - If mobility restrictions have such a negative effect on the incomes of people living in gang neighborhoods, why do the gangs continue to impose them? For instance, could the gangs benefit from loosening these restrictions and then "taxing" the additional income that residents of their territory would earn from working in other parts of the city? The main obstacle in the way of such a scheme is security. Without mobility restrictions, members of rival gangs and police informants would easily infiltrate gang neighborhoods, threatening the gangs' long-term survival.

The second obstacle is that the enforcement of such a tax system would require much more capacity than the existing one. The gangs would need to monitor individuals' income and make sure each person pays the amount they are due-things that even national governments of many countries are unable to enforce. Furthermore, if the residents of gang territory had full freedom of movement, they may not choose to live in gang neighborhoods, which would further complicate tax collection. In contrast, in the existing system, the gangs only need to monitor the boundaries of their territory and collect payments from individuals whom they allow to cross the boundary, a task that can be performed by junior gang members or collaborators. ${ }^{51}$

Finally, the enforcement of the boundaries of gang territory ensures that the gangs have not only a safe haven where they can hide but also a bridgehead from which they can conduct extortion raids into neighboring government-controlled areas. We provide a detailed discussion of this phenomenon in Subsection 5.3.

\subsection{School dropout}

While restrictions on individuals' mobility can account for a large part of the gap in labor market outcomes between gang and non-gang neighborhoods, they are less likely to be driving the differences in educational attainment. Instead, these differences are likely to be explained by higher dropout rates and lower participation in educational programs in gang-controlled neigh-

\footnotetext{
${ }^{51}$ Notably, Salvadoran gangs are not the only ones to use restrictions on individuals' mobility as a tool of control and revenue extraction. For instance, the same techniques are used by gangs in Brazil and non-state armed actors in Colombia (Ibáñez et al., 2019; Magaloni et al., 2020a). Moreover, similar mobility restrictions existed in the past during feudalism and serfdom (Bloch, 2015; Dennison, 2011; Markevich and Zhuravskaya, 2018).
} 
borhoods due to (i) recruitment by the gangs (e.g., see Sviatschi, 2022a,b), (ii) lower returns to education for people unable to work outside gang territory, and (iii) the poverty-induced need to constantly work from a young age to help provide for one's family.

To determine whether the gap in schooling can, indeed, be driven by higher dropout rates in gang territory, we perform the following analysis. We use administrative data from the 2005-2017 annual censuses of schools, in which the schools report the number of students that were enrolled at the beginning of the year and the number of students that dropped out without completing their grade. Using these data, we estimate Specification (1) with the outcome variable being the school's dropout rate, and the unit of observation-a school in a year.

Table 6 presents the results of the estimation. Column 1 shows that, on average, the annual dropout rate in schools from gang territory was 2 percentage points higher than in schools outside of gang territory. The magnitude of the effect is almost the same both before and after 2007 (Columns 2 and 3) and for male and female students (Columns 4 and 5). ${ }^{52}$ Using the result from Column 2 of Table 6 as the baseline (i.e., the difference in dropout rates before 2007), one can estimate that, during the period from 1997 to 2007 , gang control resulted in a $2.1 \times 10=21$ percentage point gap in school completion between students from gang and non-gang areas. This estimate is fully consistent with the 14.6 percentage point difference in school completion for the entire population reported in Table 1.

Importantly, although school education is usually associated with children, during the period under consideration, gang control also affected the educational attainment of many adult Salvadorans. From 1980 to 1992, El Salvador was in a state of civil war. Therefore, during that period, a large part of the population was unable to get proper education: in 1992, only 31.4\% of individuals in San Salvador had a high school degree (see Table 2). For this reason, it is not surprising that after the end of the civil war, the education of adults became an important priority for the government and was even explicitly mentioned in the Constitution, as well as in the General Law of Education (chapter VII, articles 28 to 33). In 1994-1997, the government launched the Program for Adult Literacy and Education, a policy designed to provide school-level education for the adult population. The program was very popular, and in 2000-2007 alone, 726,000 people (approximately 12\% of El Salvador's population) enrolled in PAEBA (Libreros et al., 2010). Comparing

\footnotetext{
${ }^{52}$ Table A19 in the Appendix also presents the effect on the schools' average of the high school exit exam scores (PAES) in math, natural sciences, social sciences, and Spanish language and literature. The results suggest that students in gang neighborhoods have lower test scores in all the subjects. Thus, not only do more students drop out of school in gang territory, but the remaining students also perform worse in class than their peers from non-gang areas, potentially increasing the probability that they decide not to pursue further education.
} 
the levels of educational attainment in 1992 and 2007 in gang and non-gang areas (Figures A3 and A8 in the Appendix), one can see that the share of population with a high school degree increased throughout San Salvador, but it increased much more in areas outside of gang territory. In addition to being driven by higher dropout rates among school-age children, this difference likely reflects differential enrollment in PAEBA among adults in gang and non-gang neighborhoods. We are unable to test this hypothesis directly because the implementation of PAEBA was largely community-based and was not centrally administered by any government agency. For instance, approximately $64 \%$ of classes were held in private houses, the locations of which are unknown, making it impossible to compare enrollment in gang and non-gang areas (Libreros et al., 2010). However, PAEBA was also partly implemented by the schools, which reported the completion rate of the program to the central government. We take advantage of this fact and use administrative data from the 2005-2017 annual school censuses to compare the dropout rates among adults in gang and non-gang areas. Column 6 of Table 6 presents the results, showing that adults from gang territory were significantly more likely to drop out of the program. Moreover, on average, the difference in the dropout rate between gang and non-gang neighborhoods was twice as large for adults than for school-age children, although the difference is not statistically significant.

Overall, the results presented in this subsection suggest that the differences in educational attainment between gang territory and non-gang areas are likely to be driven by differential rates of school completion in those locations. These results do not undermine the importance of the restrictions on individuals' mobility for labor market outcomes (as shown in Columns 3, 6, and 9 of Table 5, residents of gang neighborhoods have better labor market outcomes if they are able to work outside of gang territory even after controlling for the level of education), but they do indicate that even if those restrictions were to be eliminated, the gap in labor market outcomes would not fully disappear because of the differences in the levels of education.

\subsection{Extortion and other violent crimes}

Next, we consider whether lower socioeconomic development in gang areas can be explained by higher levels of extortion or other violent crimes in gang territory. To address this question, first, we use geocoded data from the 2015 survey of firms conducted by the Salvadoran Foundation for Economic and Social Development to analyze whether firms in different parts of San Salvador are differentially exposed to extortion and other types of gang activity. Specifically, we estimate Specification (1) for the probabilities that a firm has been extorted and that the firm has 
witnessed gang activity in the area where it is situated. Table 7 presents the results, showing that firms inside and outside of gang territory are equally likely to be extorted (Column 1) or witness gang activity (Column 2).

Second, we address the possibility that, although firms on each side of the boundary of gang territory have the same probability of being extorted, the amount of money that they have to pay to the gangs might be different. To analyze this question, we obtained confidential internal records on all the extortion payments that a large Salvadoran distribution firm, which operates in all parts of San Salvador municipality, has made to the gangs in 2012-2019. Column 3 of Table 7 presents the results of estimating Specification (1) for the size of the extortion payments, showing that they are the same in gang and non-gang areas. ${ }^{53}$

Third, we consider the possibility that, while firms on each side of the boundary of gang territory are equally extorted, individuals may be extorted more in gang-controlled neighborhoods. We use the data from our 2020 telephone survey in which we asked the respondents if they had ever had to pay extortion to the gangs and how much they had to pay. Columns 4 and 5 of Table 7 present the results of estimating Specification (1) for the probability that an individual has been extorted and for the amount of money paid in extortion, respectively. In both cases, there is no difference between gang and non-gang areas.

Finally, we analyze whether neighborhoods on both sides of the boundary of gang territory have similar levels of gang-related homicides and robberies. Columns 6-8 of Table 7 present the results of estimating Specification (1) for the number of gang-related homicides and robberies per square kilometer as the outcome variables, showing that there are no differences in these crimes across the boundary of gang territory. ${ }^{54}$

The results in Table 7 are not surprising and confirm the notion that both MS-13 and 18th Street operate not only in the areas they control but also in neighboring locations. Their territory is their "stronghold", a place where they do not need to hide and that, for this reason, needs to be protected from police informants and rival gang members. However, gang-controlled areas also serve as a bridgehead from which gang members and their collaborators-who are not subject to the same mobility restrictions as other people living in their territory, especially when it comes to extortion and other gang-related activities—can conduct regular raids into neighboring areas. ${ }^{55}$

\footnotetext{
${ }^{53}$ We have also verified that the frequency of these payments is the same across the boundary of gang territory, confirming the results from Column 1 of Table 7.

${ }^{54}$ The unit of observation is a 10 meter bin, denoting the distance to the boundaries of gang territory, separately for gang and non-gang areas. The results are robust to changing the size of the bins.

${ }^{55}$ Notably, for areas outside of gang territory, exposure to gang activities decreases with distance to the boundary
} 
The gang only needs to send a messenger (often children, who cannot be arrested) to contact the individual or firm. The victims then have to comply with the extortion demands or risk being hurt or killed by the gang.

The results in Table 7 have two important implications. First, they demonstrate that, since the gangs operate both in areas they control and in neighboring non-gang areas, the results in Table 1 cannot be driven by extortion or other violent crimes. These results are fully consistent with those reported in Appendix Table A18, which show that the number of business establishments-as well as their revenue, costs, and profits-does not change at boundary of gang territory, confirming the notion that businesses in gang neighborhoods do not have higher costs or lower profits because of extortion or other gang activities.

The second implication is that, since the gangs are active both in the treatment and the control group, the regression discontinuity results in Table 1 should not be interpreted to represent the overall effects of gang presence. Instead, they should be interpreted to denote the effects of gangs' territorial control and accompanying restrictions on mobility, which is likely to be the lower bound for the gangs' negative effects on socioeconomic development. This latter conjecture is supported by the results in Table 3, where the locations of the boundaries are predicted based on the presence of major geographical barriers. In Table 3 the magnitudes of the regression estimates are larger than in Table 1, which may reflect the fact that the geographical barriers prevent the gangs from conducting raids into neighboring government-controlled areas.

\subsection{Public goods provision}

Another potential determinant of lower socioeconomic development in gang neighborhoods is related to public goods provision. If neither the government nor the gangs are able and willing to provide public goods in those locations, it could have a significant impact on individuals' living conditions. To assess whether this mechanism is driving the results, we perform the following analysis. First, we use data from Google Maps on the geolocation of schools and hospitals to estimate Specification (1) using the number of schools and hospitals per square kilometer as the outcome variables. ${ }^{56}$ Second, we use data from the 2019 survey, where individuals were asked to

of gang territory, suggesting that, because of security concerns, gang members prefer to conduct their business close to the neighborhoods they control, which allows them to quickly hide from the police in case of an emergency. This fact confirms the notion that the gangs' ability to extort individuals and businesses outside of their territory is largely determined by them being able to hide from the law in neighboring areas they control.

${ }^{56}$ Google Maps has the most reliable and up-to-date geocoded data on the schools, hospitals, and other establishments in San Salvador. Administrative records are not always up to date and sometimes do not have the correct geoloca- 
rate on a scale from $1=$ "extremely unsatisfied" to 7 = "extremely satisfied" their satisfaction with the availability and quality of health services, education centers, roads, and electricity service. Table 8 presents both sets of results, showing that there are no discontinuities in any of these variables. ${ }^{57}$ In addition, as was presented in Table 2, we also find no differences in road density and in the share of urban territory. Thus, the low levels of socioeconomic development in gang areas are unlikely to be driven by differences in public goods provision.

The results in Table 8 can be explained by the fact that the government has been willing to invest in social, educational, and job training programs in gang neighborhoods, partly in order to uphold its legitimacy in the eyes of the local population (Zoethout, 2016) and partly because defunding these programs could have been costly for incumbent politicians, reducing their reelection prospects and potentially endangering their lives (Córdova, 2019).

We also analyze whether the gangs provide public goods and financial and security assistance to individuals living in their territory. Using data from the 2019 survey, we test this hypothesis by analyzing whether residents of gang neighborhoods are more likely to seek help from the gangs when they have a problem with public goods provision, a financial issue, or a security, civic, or legal dispute. ${ }^{58}$ Appendix Table A23 presents the results, showing that respondents from gang areas are not more likely to seek help from the gangs than residents of non-gang neighborhoods. However, they are more likely not to seek help from anyone, possibly out of fear that the gangs might punish them for complaining about their problems.

\section{CONCLUDING REMARKS}

The results presented in this paper have broad policy implications. First, they highlight the magnitude of the effect of non-state armed actors' territorial control on socioeconomic development in developing countries, suggesting that improvements in state capacity can significantly improve economic growth. Second, our results emphasize the importance of freedom of movement for socioeconomic development. Notably, these findings are likely to be relevant not only to other situations where non-state actors limit individuals' mobility but also to mobility across

tion of the observations (e.g., some of them are outside of El Salvador). However, if we use the data from administrative records, the results are very similar.

${ }^{57}$ In the Appendix, Figure A18 illustrates the results for the number of schools and hospitals per square kilometer; Figure A19 visualizes the results for individuals' satisfaction with the availability and quality of public goods.

${ }^{58}$ The survey could not explicitly ask about the gangs because that could have potentially endangered both the enumerators and the respondents. Therefore, we use the term "informal leader of the community" as a proxy for the gangs. When conducting the pilot of the survey, we have verified that all the pilot respondents associated the term "informal leader of the community" with the gangs. 
country borders. Finally, our findings inform about the long-term consequences of deporting individuals with criminal records to a country with low state capacity.

\section{REFERENCES}

Abrego, L., Coleman, M., Martínez, D., Menjívar, C. and Slack, J. (2017), “Making immigrants into criminals: Legal processes of criminalization in the post-IIRIRA era", Journal on Migration and Human Security, 5, 694-715.

Acemoglu, D., De FeO, G. and De LuCA, G. D. (2019), “Weak States: Causes and Consequences of the Sicilian Mafia", Review of Economic Studies, 87, 537-581.

Acemoglu, D., Johnson, S. and Robinson, J. A. (2001), "The Colonial Origins of Comparative Development: An Empirical Investigation", American Economic Review, 91, 1369-1401.

Acemoglu, D., Johnson, S. and Robinson, J. A. (2002), "Reversal of Fortune: Geography and Institutions in the Making of the Modern World Income Distribution", Quarterly Journal of Economics, 117, 1231-1294.

Acemoglu, D., Robinson, J. A. and SAntos, R. J. (2013), “The Monopoly of Violence: Evidence from Colombia", Journal of the European Economic Association, 11, 5-44.

Alesina, A., Piccolo, S. and Pinotti, P. (2019), "Organized crime, violence, and politics", Review of Economic Studies, 86, 457-499.

Alsawady, Y. A., Hassan, M. K. and Turunen-Red, A. H. (2022), "Limiting The Mobility of Migrant Workers in The Saudi Labor Market", International Journal of Economics and Management, $16,45-64$.

ARTSY, A. (2018), "Gang borders create invisible walls in Los Angeles", Tech. rep., KCWR, https://www.kcrw.com/culture/shows/design-and-architecture/gang-borders-createinvisible-walls-in-los-angeles.

Asher, S. and Novosad, P. (2020), "Rural Roads and Local Economic Development", American Economic Review, 110, 797-823.

BANDiERA, O. (2003), "Land Reform, the Market for Protection, and the Origins of the Sicilian Mafia: Theory and Evidence", Journal of Law, Economics, and Organization, 19, 218-244.

BAtES, R., GREIF, A. and SingH, S. (2002), "Organizing violence”, Journal of Conflict Resolution, 46, 599-628.

Blattman, C., DunCan, G., Lessing, B. and Tobon, S. (2022), “Gang rule: Understanding and Countering Criminal Governance", NBER Working Paper 28458.

Blattman, C. and Miguel, E. (2010), “Civil war”, Journal of Economic literature, 48, 3-57.

Bloch, M. (2015), Feudal Society (Chicago: Univerisity of Chicago Press). 
Boerman, T. and Golob, A. (2020), "Gangs and modern-day slavery in El Salvador, Honduras and Guatemala: A non-traditional model of human trafficking", Journal of Human Trafficking, $1-17$.

Brettell, C. B. (2011), “Experiencing everyday discrimination: A comparison across five immigrant populations", Race and Social Problems, 3, 266-279.

Brown, Z. Y., Montero, E., Schmidt-Padilla, C. and Sviatschi, M. M. (2020), “Market Structure and Extortion:Evidence from 50,000 Extortion Payments", NBER Working Paper.

Buonanno, P., Prarolo, G. and Vanin, P. (2016), “Organized crime and electoral outcomes. Evidence from Sicily at the turn of the XXI century", European Journal of Political Economy, 41, $61-74$.

CALİ, M. and MiAARI, S. H. (2018), "The Labor Market Impact of Mobility Restrictions: Evidence from the West Bank", Labour Economics, 51, 136-151.

Calonico, S., Cattaneo, M. D. and Farrell, M. H. (2018), "On the Effect of Bias Estimation on Coverage Accuracy in Nonparametric Inference", Journal of the American Statistical Association, $113,767-779$.

Calonico, S., Cattaneo, M. D. and Farrell, M. H. (2020), “Optimal Bandwidth Choice for Robust Bias Corrected Inference in Regression Discontinuity Designs", Econometrics Journal, forthcoming.

Calonico, S., CattaneO, M. D. and Titiunik, R. (2014), "Robust Nonparametric Confidence Intervals for Regression-Discontinuity Designs", Econometrica, 82, 2295-2326.

CARVAlho, L. S. and SoARes, R. R. (2016), "Living on the edge: Youth entry, career and exit in drug-selling gangs", Journal of Economic Behavior E Organization, 121, 77-98.

Chacón, J. M. (2009), “Managing migration through crime”, Columbia Law Review, 109, 135-148.

CHEN, X. and NordhaUs, W. D. (2011), "Using luminosity data as a proxy for economic statistics", PNAS, 108, 8589-8594.

Clemons, M., Montenegro, C. and Pritchett, L. (2008), "The great discrimination: borders as a labor market barrier", Mimeo.

Córdova, A. (2019), “Living in Gang-Controlled Neighborhoods: Impacts on Electoral and Nonelectoral Participation in El Salvador", Latin American Research Review, 54, 201-221.

Coughlin, B. C. and Venkatesh, S. A. (2003), "The urban street gang after 1970", Annual Review of Sociology, 41-64.

CRUZ, J. M. (2010), “Central American maras: From youth street gangs to transnational protection rackets", Global Crime, 11, 379-398.

CRuz, J. M. and Portillo PeÑA, N. (1998), Solidaridad y violencia en las pandillas del gran San Salvador (UCA Editores).

DANiele, G. and DipoppA, G. (2017), "Mafia, elections and violence against politicians", Journal of Public Economics, 154, 10-33. 
DANIELE, G. and GeYS, B. (2015), “Organised Crime, Institutions and Political Quality: Empirical Evidence from Italian Municipalities", The Economic Journal, 125, F233-F255.

DANIELE, V. and MARANI, U. (2011), “Organized crime, the quality of local institutions and FDI in Italy: A panel data analysis", European Journal of Political Economy, 27, 132-142.

De FeO, G. and De LuCA, G. D. (2017), "Mafia in the Ballot Box", American Economic Journal: Economic Policy, 9, 134-67.

DE LA SIERRA, R. (2020), "On the Origins of the State: Stationary Bandits and Taxation in Eastern Congo", Journal of Political Economy, 128, 32-74.

DeCESARE, D. (1998), "The children of war street gangs in el salvador", NACLA Report on the Americas, 32, 21-29.

Dell, M. (2010), “The Persistent Effects of Peru's Mining Mita”, Econometrica, 78, 1863-1903.

Dell, M. (2015), "Trafficking Networks and the Mexican Drug War", American Economic Review, $105,1738-1779$.

Dell, M., LANe, N. and Querubin, P. (2018), "The Historical State, Local Collective Action, and Economic Development in Vietnam", Econometrica, 86, 2083-2121.

Dell, M. and Olken, B. (2020), "The Development Effects of the Extractive Colonial Economy: The Dutch Cultivation System in Java", Review of Economic Studies, 87, 164-203.

Dennison, T. (2011), The Institutional Framework of Russian Serfdom (Cambridge UK: Cambridge University Press).

DONALDSON, D. (2018), "Railroads of the Raj: Estimating the Impact of Transportation Infrastructure", American Economic Review, 108, 899-934.

DunN, W. C. (2007), The Gangs of Los Angeles (iUniverse).

FrYe, T. and ZhURAVSKAYA, E. (2000), "Rackets, Regulation, and the Rule of Law", Journal of Law, Economics, E Organization, 16, 478-502.

Gambetta, D. (1996), The Sicilian Mafia: The Business of Private Protection (Cambridge MA: Harvard University Press).

GlAESER, E. and SiMS, H. (2015), "Contagion, crime, and congestion: overcoming the downsides of density", IGC Growth Brief.

Henderson, J. V., StOREyGARD, A. and Weil, D. N. (2012), "Measuring Economic Growth from Outer Space", American Economic Review, 102, 994-1028.

Ibáñez, A. M., Arteaga, J., Cárdenas Campo, J. C., Arjona, A. and Justino, P. (2019), "The Effects of Wartime Institutions on Households' Ability to Cope with Shocks: Evidence for Colombia", WIDER Working Paper № 2019/84.

Imbens, G. and Kalyanaraman, K. (2012), "Optimal Bandwidth Choice for the Regression Discontinuity Estimator", Review of Economic Studies, 79, 933-959. 
INSIGHT CRIME and CLALS (2018), "MS13 in the Americas. How the World's Most Notorious Gang Defies Logic, Resists Destruction", Tech. rep., Insight Crime and The Center for Latin American \& Latino Studies (CLALS).

International CRisis Group (2017), “El Salvador's Politics of Perpetual Violence”, Latin America Report №64.

International CRisis Group (2018), "Life Under Gang Rule in El Salvador”, Latin America $\mathcal{E}$ Caribbean Commentary.

Jones, B. F. and OlKen, B. A. (2005), “Do leaders matter? National leadership and growth since World War II", The Quarterly Journal of Economics, 120, 835-864.

Kulish, N. (2018), "What It Costs to Be Smuggled Across the U.S. Border", The New York Times.

Lessing, B. (2021), “Conceptualizing Criminal Governance”, Perspectives on Politics, 19, 854-873.

Lessing, B. and Willis, G. D. (2019), "Legitimacy in Criminal Governance: Managing a Drug Empire from Behind Bars", American Political Science Review, 113, 584-606.

LeVitT, S. and Venkatesh, S. (2000), "An Economic Analysis of a Drug-Selling Gang's Finances", Quarterly Journal of Economics, 115, 755-789.

Libreros, V., Antonio, J. and CArbajal, R. (2010), El PAEBA de El Salvador. La experiencia y el aporte de la Universidad Francisco Gavidia (San Salvador: UFG - Editores).

LOWES, S. and Montero, E. (2021), "Concessions, violence, and indirect rule: evidence from the Congo Free State", The Quarterly Journal of Economics, 136, 2047-2091.

Magaloni, B., Franco Vivanco, E. and Melo, V. (2020a), "Killing in the Slums: Social Order, Criminal Governance, and Police Violence in Rio de Janeiro", American Political Science Review, $114,552-572$.

Magaloni, B., Robles, G., Matanock, A. M., Diaz-Cayeros, A. and Romero, V. (2020b), "Living in Fear: the Dynamics of extortion in Mexico's Drug War", Comparative Political Studies, $53,1124-1174$.

MARKeVich, A. and ZhuravsKayA, E. (2018), "The Economic Effects of the Abolition of Serfdom: Evidence from the Russian Empire", American Economic Review, 108, 1074-1117.

Martínez, J. J. and Martínez, Ó. (2018), El niño de Hollywood (Penguin Random House Grupo Editorial).

Martínez, O. (2016), “Living Within the Boundaries of El Salvador's Gang 'War"', Tech. rep., Insight Crime.

Martínez, O., Lemus, E., Martínez, C. and SontaG, D. (2016), “Killers on a Shoestring: Inside the Gangs of El Salvador", The New York Times.

MCCRARY, J. (2008), "Manipulation of the running variable in the regression discontinuity design: A density tes", Journal of Econometrics, 142, 698-714.

MCKenzie, D., Stillman, S. and Gibson, J. (2010), “How Important is Selection? Experimental vs. Non-Experimental Measures of the Income Gains from Migration", Journal of the European Economic Association, 8, 913-945. 
Mergo, T. (2016), "The Effects of International Migration on Migrant-Source Households: Evidence from Ethiopian Diversity-Visa Lottery Migrants", World Development, 84, 69-81.

Michalopoulos, S. and Papaioannou, E. (2013), "Pre-Colonial Ethnic Institutions and Contemporary African Development", Econometrica, 81, 113-152.

Miguel CRUZ, J. (2010), “Central American maras: from youth street gangs to transnational protection rackets", Global Crime, 11, 379-398.

MirendA, L., Mocetti, S. and RizzicA, L. (2022), “The Economic Effects of Mafia: Firm Level Evidence", American Economic Review, forthcoming.

Murphy, T. E. and Rossi, M. A. (2020), "Following the poppy trail: Origins and consequences of Mexican drug cartels", Journal of Development Economics, 143.

Nuño, L. E. and Maguire, E. R. (2021), “The Nature and Structure of MS-13 in Los Angeles County", Criminal Justice Review, 07340168211029990.

Olson, M. (1993), “Dictatorship, Democracy, and Development”, American Political Science Review, $87,567-576$.

PAlmA, E. (1999), “Pandillas y Delincuencia en El Salvador”, Asociacíon Salvadoreña de Socioloía.

PinotTi, P. (2015), "The Causes and Consequences of Organised Crime: Preliminary Evidence Across Countries", Economic Journal, 125, F158-F174.

SAVEniJe, W. (2009), Maras y barras: pandillas y violencia juvenil en los barrios marginales de Centroamérica (FLACSO-Programa El Salvador).

SKARBEK, D. (2011), "Governance and Prison Gangs", American Political Science Review, 105, 702716.

STANLEY, W. D. (1987), "Economic migrants or refugees from violence? A time-series analysis of Salvadoran migration to the United States", Latin American Research Review, 22, 132-154.

SviAtschi, M. M. (2022a), "Making a Narco: Childhood Exposure to Illegal Labor Markets and Criminal Life Paths", Econometrica, forthcoming.

SviAtSCHI, M. M. (2022b), "Spreading Gangs: Exporting US Criminal Capital to El Salvador", American Economic Review, 112, 1985-2024.

TENORIO, O. (2002), “Tierra de todos, tierra de nadie”, Tech. rep., El Diario de Hoy, URL http: //archivo.elsalvador.com/noticias/2002/3/11/nacional/naciol4.html.

Tilly, C. (1985), "War Making and State Making as Organized crime", in "Collective Violence, Contentious Politics, and Social Change", (New York: Routledge), 121-139.

TitA, G. E., COHEN, J. and ENGBerG, J. (2005), "An ecological study of the location of gang "set space"'", Social problems, 52, 272-299.

VEGA, M. (2015), "El mapa de las pandillas", Tech. rep., El Diario de Hoy, https://historico.elsalvador.com/historico/145152/el-mapa-de-las-pandillas.html. 
Walther, O. J., Dambo, L., Koné, M. and van Eupen, M. (2020), “Mapping travel time to assess accessibility in West Africa: The role of borders, checkpoints and road conditions", Journal of Transport Geography, 82, 10-1016.

WARD, T. W. (2013), Gangsters without borders: An ethnography of a Salvadoran street gang (Oxford: Oxford University Press).

Womer, S. and BUNKER, R. J. (2010), “Sureños gangs and Mexican cartel use of social networking sites", Small Wars \& Insurgencies, 21, 81-94.

Zoethout, M. A. (2015), "Recovering Government Control over Mara Salvatrucha territory: Analysis based on the 'Santa Tecla, a Municipality Free of Violence' Agreement", Police and Public Security Journal, 5, 179-246.

Zoethout, M. A. (2016), “Consolidate State control in 'The Mara Salvatrucha (Salvatrucha gang)' territory: Lessons from community work in high-risk communities", Police and Public Security Journal, 6, 115-204. 


\section{FIGURES}

Figure 1: Gang territory in San Salvador

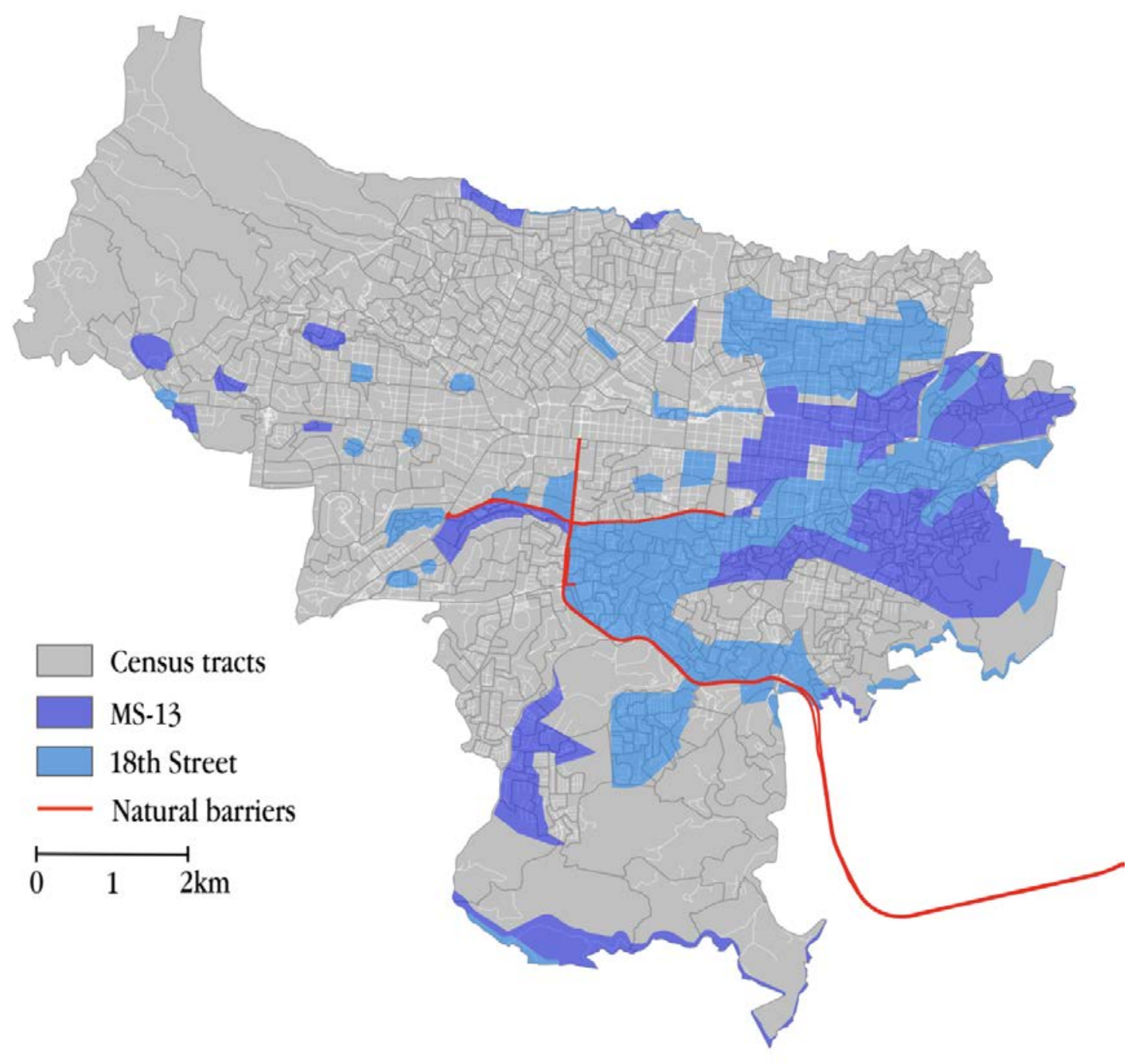


Figure 2: Socioeconomic conditions after 10 years of gang control

\section{1st principal component of the:}
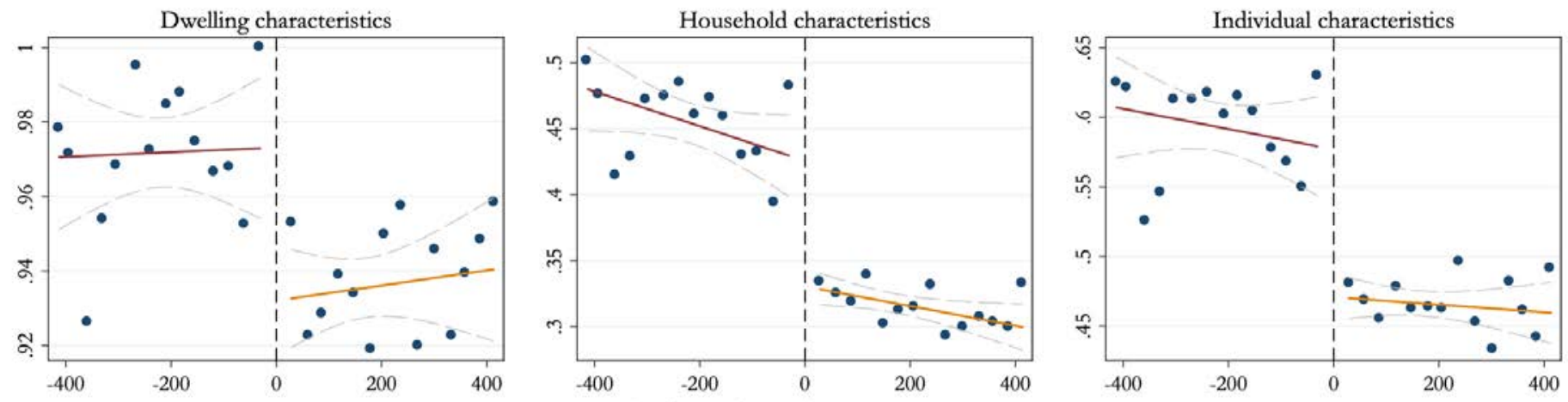

Distance to the boundary of gang territory (in meters)
- Mean of the outcome variable, by 30 meter bins
$95 \%$ confidence interval
Linear prediction (outside of gang territory) Linear prediction (gang territory)

Note: By 2007, socioeconomic conditions had become significantly worse in gang-controlled areas. The figure illustrates the results for the 1st principal components of the dwelling, household, and individual characteristics from Table 1. All the variables come from the 2007 census. The unit of observation is a dwelling, a household, and an individual, depending on the specification. All the variables are normalized to vary between zero and one with higher values representing better outcomes. The vertical axis represents the average value of the outcomes variable; the horizontal axis-distance (in meters) to the boundary of gang territory. Neighborhoods to the left of the dashed line are located outside of gang territory; areas to the right are controlled by the gangs. The dots represent the average value of the outcome variable in that 30 meter bin. 
Figure 3: Gang control and mobility constraints

\section{Share of individuals who:}
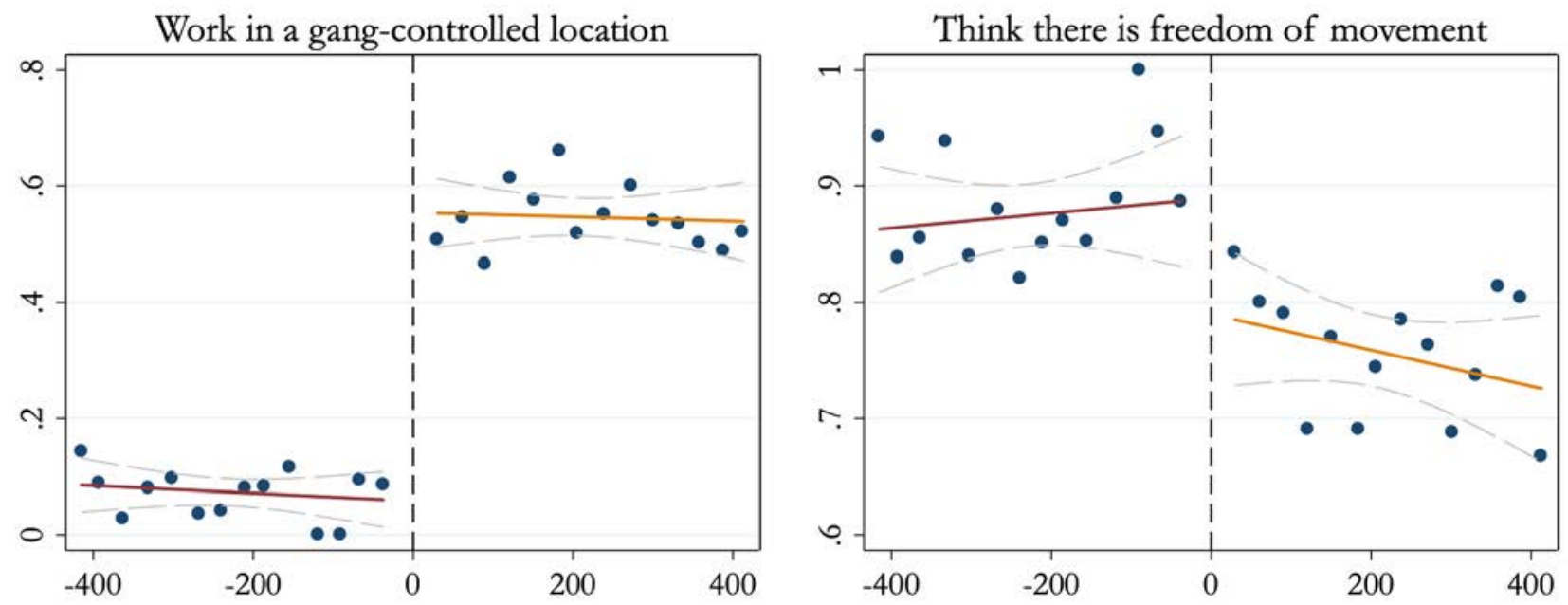

Distance to the boundary of gang territory (in meters)

Mean of the outcome variable, by 30 meter bins
Linear prediction (outside of gang territory)

Note: The figure illustrates that residents of gang territory are more likely to work in a gang-controlled location and think that there are restrictions on the freedom of movement. The vertical axis represents the average value of the outcomes variable; the horizontal axisdistance (in meters) to the boundary of gang territory. Neighborhoods to the left of the dashed line are located outside of gang territory; areas to the right are controlled by the gangs. The dots represent the average value of the outcome variable in that 30 meter bin. 


\section{TABLES}

Table 1: Socioeconomic conditions after exposure to gang control

\begin{tabular}{|c|c|c|c|c|c|c|}
\hline & \multicolumn{2}{|c|}{ Dwelling characteristics } & \multicolumn{4}{|c|}{ Household characteristics } \\
\hline & $\begin{array}{l}\text { Walls made } \\
\text { of concrete }\end{array}$ & Bare floor & $\begin{array}{l}\text { Has sewerage } \\
\text { infrastructure }\end{array}$ & $\begin{array}{l}\text { Use electricity for } \\
\text { lighting and cooking }\end{array}$ & No bathroom & Has internet \\
\hline & $(1)$ & $(2)$ & (3) & $(4)$ & (5) & $(6)$ \\
\hline Gang territory & $\begin{array}{c}-0.047 \\
(0.015)^{* * *} \\
{[0.017]^{* * *}}\end{array}$ & $\begin{array}{c}0.026 \\
(0.010)^{* *} \\
{[0.010]^{* *}}\end{array}$ & $\begin{array}{c}-0.050 \\
(0.021)^{* *} \\
{[0.027]^{*}}\end{array}$ & $\begin{array}{c}-0.079 \\
(0.021)^{* * *} \\
{[0.027]^{* * *}}\end{array}$ & $\begin{array}{c}0.006 \\
(0.002)^{* * *} \\
{[0.003]^{* *}}\end{array}$ & $\begin{array}{c}-0.131 \\
(0.029)^{* * *} \\
{[0.038]^{* * *}}\end{array}$ \\
\hline \multirow[t]{4}{*}{ Observations } & $\begin{array}{c}0.932 \\
72,252\end{array}$ & $\begin{array}{c}0.028 \\
60,820\end{array}$ & $\begin{array}{c}0.941 \\
62,316\end{array}$ & $\begin{array}{c}0.108 \\
62,316\end{array}$ & $\begin{array}{c}0.005 \\
62,316\end{array}$ & $\begin{array}{c}0.180 \\
59,917\end{array}$ \\
\hline & \multicolumn{6}{|c|}{ Household characteristics } \\
\hline & Has a motorcycle & Has a car & Has a phone & Has a TV & Has a computer & Number of rooms \\
\hline & $(7)$ & $(8)$ & $(9)$ & $(10)$ & $(11)$ & $(12)$ \\
\hline Gang territory & $\begin{array}{c}-0.013 \\
(0.006)^{* *} \\
{[0.005]^{* *}}\end{array}$ & $\begin{array}{c}-0.207 \\
(0.046)^{* * *} \\
{[0.057]^{* * *}}\end{array}$ & $\begin{array}{c}-0.135 \\
(0.033)^{* * *} \\
{[0.040]^{* * *}}\end{array}$ & $\begin{array}{c}-0.021 \\
(0.006)^{* * *} \\
{[0.008]^{* *}}\end{array}$ & $\begin{array}{c}-0.173 \\
(0.035)^{* * *} \\
{[0.045]^{* * *}}\end{array}$ & $\begin{array}{c}-0.693 \\
(0.195)^{* * *} \\
{[0.203]^{* * *}}\end{array}$ \\
\hline \multirow[t]{4}{*}{ Observations } & $\begin{array}{c}0.033 \\
59,237\end{array}$ & $\begin{array}{c}0.428 \\
60,186\end{array}$ & $\begin{array}{c}0.696 \\
60,309\end{array}$ & $\begin{array}{c}0.952 \\
60,525\end{array}$ & $\begin{array}{c}0.346 \\
60,161\end{array}$ & $\begin{array}{c}3.089 \\
62,316\end{array}$ \\
\hline & \multicolumn{3}{|c|}{ Individual characteristics } & \multicolumn{3}{|c|}{ 1st principal component of the: } \\
\hline & $\begin{array}{l}\text { Can read } \\
\text { and write }\end{array}$ & $\begin{array}{c}\text { Has a high } \\
\text { school degree }\end{array}$ & $\begin{array}{c}\text { Has a university } \\
\text { degree }\end{array}$ & $\begin{array}{c}\text { Dwelling } \\
\text { characteristics }\end{array}$ & $\begin{array}{c}\text { Household } \\
\text { characteristics }\end{array}$ & $\begin{array}{c}\text { Individual } \\
\text { characteristics }\end{array}$ \\
\hline & (13) & $(14)$ & $(15)$ & $(16)$ & $(17)$ & $(18)$ \\
\hline Gang territory & $\begin{array}{c}-0.032 \\
(0.007)^{* * *} \\
{[0.008]^{* * *}}\end{array}$ & $\begin{array}{c}-0.153 \\
(0.029)^{* * *} \\
{[0.034]^{* * *}}\end{array}$ & $\begin{array}{c}-0.121 \\
(0.026)^{* * *} \\
{[0.030]^{* * *}}\end{array}$ & $\begin{array}{c}-0.036 \\
(0.012)^{* * *} \\
{[0.013]^{* * *}}\end{array}$ & $\begin{array}{c}-0.089 \\
(0.019)^{* * *} \\
{[0.024]^{* * *}}\end{array}$ & $\begin{array}{c}-0.101 \\
(0.020)^{* * *} \\
{[0.023]^{* * *}}\end{array}$ \\
\hline $\begin{array}{l}\text { Mean of dep. var. } \\
\text { Observations }\end{array}$ & $\begin{array}{c}0.928 \\
208,913\end{array}$ & $\begin{array}{c}0.448 \\
203,423\end{array}$ & $\begin{array}{c}0.207 \\
203,423\end{array}$ & $\begin{array}{c}0.952 \\
60,820\end{array}$ & $\begin{array}{c}0.377 \\
58,434\end{array}$ & $\begin{array}{c}0.521 \\
203,423\end{array}$ \\
\hline
\end{tabular}

Note: ${ }^{* * *} \mathrm{p}<0.01,{ }^{* *} \mathrm{p}<0.05,{ }^{*} \mathrm{p}<0.1$. After experiencing gang control, gang-controlled areas have worse socioeconomic conditions than neighboring areas that were not under the control of gangs. The table presents the results of estimating Specification (1) for the variables from the 2007 census. The unit of observation is a dwelling, household, or individual, depending on which characteristics are being considered. In the individual-level regressions, the sample consists of the entire population. Omitted controls include a linear trend in distance to the boundary of gang territory, separately for locations on each side of the boundary. Standard errors in parentheses are clustered by 30 meter bins, denoting the distance to gang territory (separately for each side of the boundary). Standard errors in brackets are adjusted to allow for spatial correlation within a 100 meter radius (Conley correction). 
Table 2: Geographic and socioeconomic characteristics before the arrival of the gangs

\begin{tabular}{|c|c|c|c|c|c|c|}
\hline & \multicolumn{6}{|c|}{ Neighborhood characteristics } \\
\hline & Urban territory & Road density & $\begin{array}{l}\text { Has access to } \\
\text { the waterways }\end{array}$ & Elevation & $\begin{array}{l}\text { Territory used for } \\
\text { coffee production }\end{array}$ & Tree coverage \\
\hline & $(1)$ & $(2)$ & (3) & $(4)$ & (5) & (6) \\
\hline Gang territory & $\begin{array}{l}-0.011 \\
(0.064) \\
{[0.053]}\end{array}$ & $\begin{array}{c}-0.522 \\
(0.951) \\
{[1.843]}\end{array}$ & $\begin{array}{c}0.018 \\
(0.065) \\
{[0.095]}\end{array}$ & $\begin{array}{c}0.506 \\
(16.286) \\
{[17.354]}\end{array}$ & $\begin{array}{c}0.009 \\
(0.019) \\
{[0.023]}\end{array}$ & $\begin{array}{l}-0.004 \\
(0.026) \\
{[0.026]}\end{array}$ \\
\hline \multirow[t]{4}{*}{ Observations } & $\begin{array}{c}0.812 \\
477\end{array}$ & $\begin{array}{c}17.83 \\
477\end{array}$ & $\begin{array}{c}0.327 \\
477\end{array}$ & $\begin{array}{c}720.39 \\
477\end{array}$ & $\begin{array}{c}0.049 \\
477\end{array}$ & $\begin{array}{c}0.028 \\
477\end{array}$ \\
\hline & \multicolumn{2}{|c|}{ Dwelling characteristics } & \multicolumn{4}{|c|}{ Household characteristics } \\
\hline & $\begin{array}{l}\text { Walls made } \\
\text { of concrete }\end{array}$ & Bare floor & $\begin{array}{l}\text { Has sewerage } \\
\text { infrastructure }\end{array}$ & $\begin{array}{l}\text { Use electricity for } \\
\text { lighting and cooking }\end{array}$ & No bathroom & Shared bathroom \\
\hline & (7) & (8) & (9) & $(10)$ & (11) & $(12)$ \\
\hline Gang territory & $\begin{array}{l}-0.015 \\
(0.036) \\
{[0.035]}\end{array}$ & $\begin{array}{l}-0.003 \\
(0.028) \\
{[0.030]}\end{array}$ & $\begin{array}{c}-0.032 \\
(0.047) \\
{[0.046]}\end{array}$ & $\begin{array}{l}-0.036 \\
(0.039) \\
{[0.030]}\end{array}$ & $\begin{array}{l}-0.007 \\
(0.017) \\
{[0.013]}\end{array}$ & $\begin{array}{c}0.021 \\
(0.032) \\
{[0.029]}\end{array}$ \\
\hline \multirow[t]{4}{*}{ Observations } & $\begin{array}{c}0.813 \\
64,899\end{array}$ & $\begin{array}{c}0.010 \\
64,899\end{array}$ & $\begin{array}{c}0.816 \\
64,899\end{array}$ & $\begin{array}{c}0.182 \\
64,899\end{array}$ & $\begin{array}{c}0.030 \\
64,899\end{array}$ & $\begin{array}{c}0.142 \\
64,899\end{array}$ \\
\hline & \multicolumn{6}{|c|}{ Household characteristics } \\
\hline & Has a motorcycle & Has a car & Has a phone & Has a TV & Has a blender & Number of rooms \\
\hline & (13) & (14) & (15) & (16) & (17) & (18) \\
\hline Gang territory & $\begin{array}{l}-0.004 \\
(0.009) \\
{[0.007]}\end{array}$ & $\begin{array}{l}-0.049 \\
(0.051) \\
{[0.043]}\end{array}$ & $\begin{array}{l}-0.030 \\
(0.054) \\
{[0.049]}\end{array}$ & $\begin{array}{c}0.009 \\
(0.019) \\
{[0.019]}\end{array}$ & $\begin{array}{c}0.014 \\
(0.032) \\
{[0.034]}\end{array}$ & $\begin{array}{l}-0.069 \\
(0.170) \\
{[0.172]}\end{array}$ \\
\hline $\begin{array}{l}\text { Mean of dep. var. } \\
\text { Observations }\end{array}$ & $\begin{array}{c}0.034 \\
64,899\end{array}$ & $\begin{array}{c}0.285 \\
64,899\end{array}$ & $\begin{array}{c}0.320 \\
64,899\end{array}$ & $\begin{array}{c}0.860 \\
64,899\end{array}$ & $\begin{array}{c}0.625 \\
64,899\end{array}$ & $\begin{array}{c}2.670 \\
64,899\end{array}$ \\
\hline \multirow{3}{*}{ Observations } & \multicolumn{3}{|c|}{ Individual characteristics } & \multicolumn{3}{|c|}{ 1st principal component of the: } \\
\hline & $\begin{array}{l}\text { Can read } \\
\text { and write }\end{array}$ & $\begin{array}{c}\text { Has a high } \\
\text { school degree }\end{array}$ & $\begin{array}{c}\text { Has a university } \\
\text { degree }\end{array}$ & $\begin{array}{c}\text { Dwelling } \\
\text { characteristics }\end{array}$ & $\begin{array}{c}\text { Household } \\
\text { characteristics }\end{array}$ & $\begin{array}{c}\text { Individual } \\
\text { characteristics }\end{array}$ \\
\hline & (19) & $(20)$ & $(21)$ & $(22)$ & $(23)$ & $(24)$ \\
\hline Gang territory & $\begin{array}{l}-0.000 \\
(0.011) \\
{[0.009]}\end{array}$ & $\begin{array}{l}-0.014 \\
(0.028) \\
{[0.028]}\end{array}$ & $\begin{array}{l}-0.019 \\
(0.017) \\
{[0.017]}\end{array}$ & $\begin{array}{l}-0.005 \\
(0.031) \\
{[0.031]}\end{array}$ & $\begin{array}{l}-0.016 \\
(0.030) \\
{[0.026]}\end{array}$ & $\begin{array}{l}-0.013 \\
(0.018) \\
{[0.018]}\end{array}$ \\
\hline \multirow[t]{4}{*}{ Observations } & $\begin{array}{c}0.904 \\
234,749\end{array}$ & $\begin{array}{c}0.314 \\
227,281\end{array}$ & $\begin{array}{c}0.112 \\
227,281\end{array}$ & $\begin{array}{c}0.863 \\
64,899\end{array}$ & $\begin{array}{c}0.525 \\
64,899\end{array}$ & $\begin{array}{c}0.380 \\
227,281\end{array}$ \\
\hline & \multicolumn{6}{|c|}{ Number of incarcerations per $\mathrm{km}^{2}$ prior to 1997 : } \\
\hline & All crimes & Homicide & Robbery & Sex crimes & Assault & Other violent crimes \\
\hline & $(25)$ & $(26)$ & (27) & $(28)$ & (29) & $(30)$ \\
\hline Gang territory & $\begin{array}{c}-2.096 \\
(18.200)\end{array}$ & $\begin{array}{c}1.464 \\
(1.297)\end{array}$ & $\begin{array}{l}-0.316 \\
(4.016)\end{array}$ & $\begin{array}{c}-1.648 \\
(1.278)\end{array}$ & $\begin{array}{c}0.315 \\
(3.886)\end{array}$ & $\begin{array}{l}-1.212 \\
(1.787)\end{array}$ \\
\hline Mean of dep. var. & 114.60 & 4.670 & 22.64 & 6.588 & 20.86 & 9.711 \\
\hline Observations & 86 & 86 & 86 & 86 & 86 & 86 \\
\hline
\end{tabular}

Note: ${ }^{* * *} \mathrm{p}<0.01,{ }^{* *} \mathrm{p}<0.05,{ }^{*} \mathrm{p}<0.1$. Before the arrival of the gangs, locations on either side of the boundary of gang territory had similar geographic and socioeconomic characteristics. The table presents the results of estimating Specification (1) for the neighborhood chracteristics and the variables from the 1992 census. The unit of observation is a census tract, dwelling, household, or individual, depending on which characteristics are being considered. In the individual-level regressions, the sample consists of the entire population. Omitted controls include a linear trend in distance to the boundary of gang territory, separately for locations on each side of the boundary. Standard errors in parentheses are clustered by 30 meter bins, denoting the distance to the boundary of gang territory (separately for each side of the boundary). Standard errors in brackets are adjusted to allow for spatial correlation within a 100 meter radius (Conley correction). In Columns 25-30, the Conley standard errors are not reported because there the location of the observations is not defined (the unit of observation is a 10 meter bin, denoting the distance to the boundary of gang territory). 
Table 3: Boundaries of gang territory from geographical barriers

\begin{tabular}{|c|c|c|c|c|c|c|}
\hline & \multicolumn{2}{|c|}{ Dwelling characteristics } & \multicolumn{4}{|c|}{ Household characteristics } \\
\hline & $\begin{array}{l}\text { Walls made } \\
\text { of concrete }\end{array}$ & Bare floor & $\begin{array}{l}\text { Has sewerage } \\
\text { infrastructure }\end{array}$ & $\begin{array}{c}\text { Use electricity for } \\
\text { lighting and cooking }\end{array}$ & No bathroom & Has internet \\
\hline & $(1)$ & $(2)$ & (3) & $(4)$ & (5) & (6) \\
\hline Gang territory & $\begin{array}{l}-0.055^{*} \\
(0.028)\end{array}$ & $\begin{array}{c}0.037^{* * *} \\
(0.010)\end{array}$ & $\begin{array}{c}-0.054^{* * *} \\
(0.013)\end{array}$ & $\begin{array}{l}-0.083^{*} \\
(0.043)\end{array}$ & $\begin{array}{l}0.005^{* *} \\
(0.002)\end{array}$ & $\begin{array}{c}-0.109^{* *} \\
(0.045)\end{array}$ \\
\hline Mean of dep. var. & 0.945 & 0.021 & 0.969 & 0.064 & 0.003 & 0.124 \\
\hline \multirow[t]{4}{*}{ Observations } & 10,047 & 8,418 & 8,684 & 8,684 & 8,684 & 8,260 \\
\hline & \multicolumn{6}{|c|}{ Household characteristics } \\
\hline & Has a motorcycle & Has a car & Has a phone & Has a TV & Has a computer & Number of rooms \\
\hline & (7) & $(8)$ & (9) & $(10)$ & $(11)$ & $(12)$ \\
\hline Gang territory & $\begin{array}{c}-0.016^{* * *} \\
(0.005)\end{array}$ & $\begin{array}{c}-0.366^{* * *} \\
(0.069)\end{array}$ & $\begin{array}{c}-0.216^{* * *} \\
(0.043)\end{array}$ & $\begin{array}{c}-0.031^{*} \\
(0.016)\end{array}$ & $\begin{array}{c}-0.276^{* * *} \\
(0.065)\end{array}$ & $\begin{array}{c}-1.310^{* *} \\
(0.486)\end{array}$ \\
\hline Mean of dep. var. & 0.034 & 0.366 & 0.697 & 0.958 & 0.291 & 2.978 \\
\hline \multirow[t]{4}{*}{ Observations } & 8,183 & 8,296 & 8,314 & 8,355 & 8,293 & 8,684 \\
\hline & \multicolumn{3}{|c|}{ Individual characteristics } & \multicolumn{3}{|c|}{ 1st principal component of the: } \\
\hline & $\begin{array}{l}\text { Can read } \\
\text { and write }\end{array}$ & $\begin{array}{c}\text { Has a high } \\
\text { school degree }\end{array}$ & $\begin{array}{c}\text { Has a university } \\
\text { degree }\end{array}$ & $\begin{array}{c}\text { Dwelling } \\
\text { characteristics }\end{array}$ & $\begin{array}{c}\text { Household } \\
\text { characteristics }\end{array}$ & $\begin{array}{c}\text { Individual } \\
\text { characteristics }\end{array}$ \\
\hline & (13) & $(14)$ & (15) & $(16)$ & $(17)$ & (18) \\
\hline Gang territory & $\begin{array}{c}-0.088^{* *} \\
(0.038)\end{array}$ & $\begin{array}{c}-0.291^{* * *} \\
(0.044)\end{array}$ & $\begin{array}{c}-0.210^{* * *} \\
(0.048)\end{array}$ & $\begin{array}{c}-0.046^{* *} \\
(0.020)\end{array}$ & $\begin{array}{c}-0.134^{* * *} \\
(0.029)\end{array}$ & $\begin{array}{c}-0.195^{* * *} \\
(0.028)\end{array}$ \\
\hline Mean of dep. var. & 0.927 & 0.436 & 0.171 & 0.962 & 0.354 & 0.505 \\
\hline Observations & 29,268 & 28,195 & 28,195 & 8,418 & 8,063 & 28,195 \\
\hline
\end{tabular}

Note: ${ }^{* *} \mathrm{p}<0.01,{ }^{* *} \mathrm{p}<0.05,{ }^{*} \mathrm{p}<0.1$. The table presents the results of estimating Specification (1), using the locations of major roads and boulevards (geographical barriers) as the predicted boundaries of gang territory. All the variables come from the 2007 census. The unit of observation is a dwelling, household, or individual, depending on which characteristics are being considered. In the individual-level regressions, the sample consists of the entire population. Omitted controls include a linear trend in distance to the boundary of gang territory, separately for locations on each side of the boundary. Standard errors in parentheses are clustered by 30 meter bins, denoting the distance to the predicted boundary of gang territory (separately for each side of the boundary). 
Table 4: Gang control and restrictions on individuals' mobility

\begin{tabular}{lcccccc}
\hline & $\begin{array}{c}\text { Works in } \\
\text { gang territory }\end{array}$ & $\begin{array}{c}\text { Works in the same } \\
\text { neighborhood } \\
\text { where they live }\end{array}$ & $\begin{array}{c}\text { Has been to } \\
\text { Santa Ana } \\
\text { department }\end{array}$ & $\begin{array}{c}\text { Has been to } \\
\text { the beach }\end{array}$ & $\begin{array}{c}\text { Has always lived } \\
\text { in this location }\end{array}$ & $\begin{array}{c}\text { Freedom of } \\
\text { movement } \\
\text { where they live }\end{array}$ \\
\cline { 2 - 6 } & $(1)$ & $(2)$ & $(3)$ & $(4)$ & $(5)$ & $(6)$ \\
\hline Gang territory & 0.495 & 0.111 & -0.277 & -0.064 & 0.172 & -0.097 \\
& $(0.039)^{* * *}$ & $(0.031)^{* * *}$ & $(0.043)^{* * *}$ & $(0.031)^{* *}$ & $(0.045)^{* * *}$ & $(0.039)^{* *}$ \\
Mean of dep. var. & {$[0.042]^{* * *}$} & {$[0.050]^{* *}$} & {$[0.052]^{* * *}$} & {$[0.032]^{* *}$} & {$[0.055]^{* * *}$} & {$[0.039]^{* *}$} \\
Observations & 0.334 & 0.302 & 0.495 & 0.872 & 0.772 & 0.811 \\
\hline
\end{tabular}

Note: ${ }^{* *} \mathrm{p}<0.01,{ }^{* *} \mathrm{p}<0.05,{ }^{*} \mathrm{p}<0.1$. The table presents the results of estimating Specification (1) for the mobility questions from the 2019 survey. Santa Ana is a neighboring department, which is approximately 60 kilometers away from San Salvador. The sea is approximately 30 kilometers away from San Salvador. The unit of observation is an individual. Omitted controls include a linear trend in distance to the boundary of gang territory, separately for locations on each side of the boundary. Standard errors in parentheses are clustered by 30 meter bins, denoting the distance to the boundary of gang territory (separately for each side of the boundary). Standard errors in brackets are adjusted to allow for spatial correlation within a 100 meter radius (Conley correction). 
Table 5: Consequences of low labor mobility

\begin{tabular}{|c|c|c|c|c|c|c|c|c|c|}
\hline & \multicolumn{3}{|c|}{ Household income } & \multicolumn{3}{|c|}{$\begin{array}{l}\text { Works in a firm with } \\
\geq 100 \text { employees }\end{array}$} & \multicolumn{3}{|c|}{$\begin{array}{l}\text { Works in a firm with } \\
\geq 200 \text { employees }\end{array}$} \\
\hline & $(1)$ & $(2)$ & (3) & (4) & (5) & (6) & $(7)$ & $(8)$ & (9) \\
\hline Lives in gang territory & $\begin{array}{c}-352.60 \\
(112.22)^{* * *} \\
{[84.97]^{* * *}}\end{array}$ & $\begin{array}{c}-429.99 \\
(127.82)^{* * * *} \\
{[98.80]^{* * *}}\end{array}$ & $\begin{array}{c}-235.09 \\
(112.56)^{* *} \\
{[81.33]^{* * *}}\end{array}$ & $\begin{array}{c}-0.123 \\
(0.019)^{* * *} \\
{[0.042]^{* * *}}\end{array}$ & $\begin{array}{c}-0.210 \\
(0.022)^{* * *} \\
{[0.046]^{* * *}}\end{array}$ & $\begin{array}{c}-0.105 \\
(0.023)^{* * *} \\
{[0.041]^{* * *}}\end{array}$ & $\begin{array}{c}-0.115 \\
\left(0.0288^{* * *}\right. \\
{[0.035]^{* * *}}\end{array}$ & $\begin{array}{c}-0.187 \\
(0.025)^{* * *} \\
{[0.038]^{* * *}}\end{array}$ & $\begin{array}{c}-0.102 \\
(0.030)^{* * *} \\
{[0.035]^{* * *}}\end{array}$ \\
\hline $\begin{array}{l}\text { Lives in gang territory, } \\
\text { works in non-gang territory }\end{array}$ & & $\begin{array}{c}167.64 \\
(32.69)^{* * * *} \\
{[37.08]^{* * *}}\end{array}$ & $\begin{array}{c}85.39 \\
(30.23)^{* * *} \\
{[38.73]^{* *}}\end{array}$ & & $\begin{array}{c}0.182 \\
(0.026)^{* * *} \\
{[0.025]^{* * *}}\end{array}$ & $\begin{array}{c}0.129 \\
(0.025)^{* * *} \\
{[0.024]^{* * *}}\end{array}$ & & $\begin{array}{c}0.152 \\
(0.027)^{* * *} \\
{[0.024]^{* * *}}\end{array}$ & $\begin{array}{c}0.110 \\
(0.026)^{* * *} \\
{[0.023]^{* * *}}\end{array}$ \\
\hline Has a high school degree & & & $\begin{array}{c}89.11 \\
(19.90)^{* * *} \\
{[26.78]^{* * *}}\end{array}$ & & & $\begin{array}{c}0.124 \\
(0.021)^{* * * *} \\
{[0.020]^{* * *}}\end{array}$ & & & $\begin{array}{c}0.088 \\
(0.018)^{* * * *} \\
{[0.019]^{* * *}}\end{array}$ \\
\hline Has a university degree & & & $\begin{array}{c}445.46 \\
(76.96)^{* * *} \\
{[62.62]^{* * *}}\end{array}$ & & & $\begin{array}{c}0.148 \\
(0.029)^{* * *} \\
{[0.032]^{* * *}}\end{array}$ & & & $\begin{array}{c}0.132 \\
(0.027)^{* * *} \\
{[0.030]^{* * *}}\end{array}$ \\
\hline Mean c & 625.00 & 634.70 & 638.90 & 0.169 & 0.169 & 0.170 & 0.133 & 0.132 & 0.132 \\
\hline Observations & 2,314 & 1,738 & 1,707 & 2,071 & 1,738 & 1,707 & 2,071 & 1,738 & 1,707 \\
\hline
\end{tabular}

Note: ${ }^{* * *} \mathrm{p}<0.01,{ }^{* *} \mathrm{p}<0.05,{ }^{*} \mathrm{p}<0.1$. The table shows that the discontinuity in income and firm size is significantly smaller or nonexistent for individuals living in gang territory but working outside of gang territory. All the variables come from the 2019 survey. For household income, the unit of observation is a household; for the other variables - an individual. Omitted controls include a linear trend in distance to the boundary of gang territory, separately for locations on each side of the boundary, and a dummy for whether the individual is currently employed (in the survey, unemployed individuals were asked to describe their most recent work experience). Standard errors in parentheses are clustered by 30 meter bins, denoting the distance to the boundary of gang territory, separately for each side of the boundary. Standard errors in brackets are adjusted to allow for spatial correlation within a 100 meter radius (Conley correction). 
Table 6: Gang control and dropout rates

\begin{tabular}{|c|c|c|c|c|c|c|}
\hline \multirow{3}{*}{ Subsample: } & \multicolumn{6}{|c|}{ Dropout rate } \\
\hline & All obs. & Year $\leq 2007$ & Year $>2007$ & Male & Female & All obs. \\
\hline & (1) & (2) & (3) & (4) & (5) & (6) \\
\hline Gang territory & $\begin{array}{c}0.019 \\
(0.004)^{* * *} \\
{[0.007]^{* * *}}\end{array}$ & $\begin{array}{c}0.021 \\
(0.008)^{* *} \\
{[0.009]^{* *}}\end{array}$ & $\begin{array}{c}0.018 \\
(0.004)^{* * *} \\
{[0.007]^{* *}}\end{array}$ & $\begin{array}{c}0.021 \\
(0.006)^{* * *} \\
{[0.008]^{* * *}}\end{array}$ & $\begin{array}{c}0.019 \\
(0.003)^{* * *} \\
{[0.006]^{* * *}}\end{array}$ & \\
\hline Gang territory $\times$ Standard program & & & & & & $\begin{array}{c}0.019 \\
(0.004)^{* * *} \\
{[0.007]^{* * *}}\end{array}$ \\
\hline Gang territory $\times$ Program for adults & & & & & & $\begin{array}{c}0.038 \\
(0.018)^{* *} \\
{[0.017]^{* *}}\end{array}$ \\
\hline Mean of dep. var. & 0.020 & 0.021 & 0.019 & 0.023 & 0.016 & 0.020 \\
\hline Observations & 3,199 & 684 & 2,515 & 3,088 & 3,186 & 3,377 \\
\hline
\end{tabular}

Note: ${ }^{* *} \mathrm{p}<0.01,{ }^{* *} \mathrm{p}<0.05,{ }^{*} \mathrm{p}<0.1$. The table presents the results for estimating Specification (1) for the dropout rates for schools in San Salvador. The data come from the annual census of schools. In Columns 1-5, the unit of observation is a school in a year. In these results, omitted controls include a linear trend in distance to the boundary of gang territory, separately for locations on each side of the boundary. In Column 6, the unit of observation is the type of program (standard or for adults) in a school in a year. In these results, omitted controls include a dummy for the program being for adults and linear trends in distance to the boundary of gang territory, separately for each type of program on each side of the boundary. Standard errors in parentheses are clustered by 30 meter bins, denoting the distance to the boundary of gang territory (separately for each side of the boundary). Standard errors in brackets are adjusted to allow for spatial correlation within a 100 meter radius (Conley correction). 
Table 7: Extortion and violence

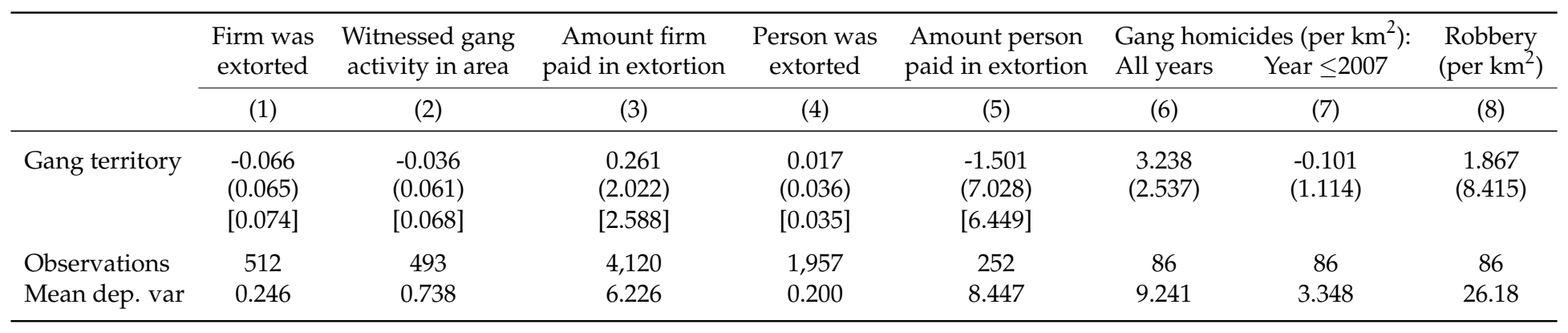

Note: ${ }^{* *} \mathrm{p}<0.01,{ }^{* *} \mathrm{p}<0.05,{ }^{*} \mathrm{p}<0.1$. The table presents the results of estimating Specification (1) for extortion and other gang-related violent crimes. In Columns 1-2, the unit of observation is a firm in the 2015 survey of firms conducted by FUSADES. In Column 3 , the unit of observation is an instance when a firm had to make an extortion payment to the gang. These data come from confidential internal records of one of the larger firms in El Salvador. In Columns 4-5, the unit of observation is an individual in our own 2020 survey. In Columns 6-8, the unit of observation is a 10 meter bin, denoting the distance to the boundary of gang territory, weighted by the size of the area of the distance bins. These data come from official police records. Omitted controls include a linear trend in distance to the boundary of gang territory, separately for locations on each side of the boundary. Standard errors in parentheses are clustered by 30 meter bins, denoting the distance to the boundary of gang territory (separately for each side of the boundary). Standard errors in brackets are adjusted to allow for spatial correlation within a 100 meter radius (Conley correction). In Columns 6-8, the Conley standard errors are not reported because there the location of the observations is not defined (the unit of observation is a 10 meter bin, denoting the distance to the boundary of gang territory). 
Table 8: Public goods provision in gang-controlled locations

\begin{tabular}{|c|c|c|c|c|c|c|}
\hline & \multicolumn{2}{|c|}{ Number per $\mathrm{km}^{2}$ : } & \multicolumn{4}{|c|}{$\begin{array}{l}\text { On a scale from } 1 \text { to } 7 \text {, satisfaction } \\
\text { with the availability and quality of: }\end{array}$} \\
\hline & Schools & Hospitals & $\begin{array}{l}\text { Health } \\
\text { services }\end{array}$ & $\begin{array}{l}\text { Education } \\
\text { centers }\end{array}$ & Roads & $\begin{array}{l}\text { Electricity } \\
\text { service }\end{array}$ \\
\hline & (1) & (2) & (3) & (4) & (5) & (6) \\
\hline Gang territory & $\begin{array}{c}0.325 \\
(1.689)\end{array}$ & $\begin{array}{l}-0.271 \\
(0.692)\end{array}$ & $\begin{array}{c}0.173 \\
(0.172) \\
{[0.189]}\end{array}$ & $\begin{array}{l}-0.019 \\
(0.173) \\
{[0.170]}\end{array}$ & $\begin{array}{c}0.299 \\
(0.338) \\
{[0.302]}\end{array}$ & $\begin{array}{l}-0.083 \\
(0.125) \\
{[0.098]}\end{array}$ \\
\hline $\begin{array}{l}\text { Mean of dep. var. } \\
\text { Observations }\end{array}$ & $\begin{array}{c}5.786 \\
86\end{array}$ & $\begin{array}{c}1.805 \\
86\end{array}$ & $\begin{array}{l}4.080 \\
2,314\end{array}$ & $\begin{array}{l}4.696 \\
2,314\end{array}$ & $\begin{array}{l}4.263 \\
2,314\end{array}$ & $\begin{array}{l}5.873 \\
2,314\end{array}$ \\
\hline
\end{tabular}

Note: ${ }^{* *} \mathrm{p}<0.01,{ }^{* *} \mathrm{p}<0.05,{ }^{*} \mathrm{p}<0.1$. The table presents the results for estimating Specification (1) for the variables related to public goods provision. The questions about the satisfaction with the availability and quality of public goods come from the 2019 survey. For those variables, the unit of observation is an individual. The data on the number of schools and hospitals come from Google Maps. For those variables, the unit of observation is a 10 meter bin, denoting the distance to the boundary of gang territory, separately for each side of the boundary. Omitted controls include a linear trend in distance to the boundary of gang territory, separately for locations on each side of the boundary. Standard errors in parentheses are clustered by 30 meter bins, denoting the distance to the boundary of gang territory (separately for each side of the boundary). Standard errors in brackets are adjusted to allow for spatial correlation within a 100 meter radius (Conley correction). In Columns 1-2, the Conley standard errors are not reported because there the location of the observations is not defined (the unit of observation is a 10 meter bin, denoting the distance to the boundary of gang territory). 


\section{ONLINE APPENDIX}

\section{A. DATA}

\section{A.1. Additional data sources}

Urban territory.-The data on urban density come from New York University's Atlas of Urban Expansion. The raster map presents the urban areas in the Greater San Salvador region in $1999 .{ }^{59}$ We transform the data into a binary raster, equal to one when the location is classified as urban. Then, for each of the census tracts from the 2007 census, we calculate the share of census tracts' territory that is urban.

Waterways.-The map of the waterways in El Salvador comes from the Humanitarian OpenStreetMap Team. ${ }^{60}$ Then, for each of the census tracts from the 2007 census, we created a dummy variable for whether the census tract contains a part of the waterway.

Road density. - The map of the roads in El Salvador comes from the Humanitarian OpenStreetMap Team and reflects the roads that existed in the country in March $2020 .{ }^{61}$ We then transform the feature-based map into a binary raster file with the resolution of 1 meter $\times 1$ meter, where we replace the lines for roads with grid cells equal to one. After that, for each of the census tracts from the 2007 census, we calculate road density, measured in kilometers per square kilometer.

Elevation.-The data on elevation at the resolution of 3 arc seconds (approximately 90 meters) come from the CGIAR-Consortium for Spatial Information (CGIAR-CSI). ${ }^{62}$ For each of the census tracts from the 2007 census, we calculate the average elevation inside the census tract.

Territory used for coffee production - The map of land use in 1998 (including coffee production) comes from the Ministry of Environment and Natural Resources (Ministerio de Medio Ambiente y Recursos Naturales, MARN). We convert the feature-based map into a binary raster, equal to one for areas that are used for coffee production. Then, for each of the census tracts from the 2007 census, we calculate the share of census tracts' territory that is used for coffee production.

Tree coverage.-The data on tree coverage in 2000 come from Global Forest Watch. ${ }^{63}$ The

\footnotetext{
${ }^{59}$ The San Salvador profile can be accessed here: Atlas of Urban Expansion: San Salvador (accessed on May 4, 2020).

${ }^{60}$ The map of the waterways in El Salvador can be accessed here: Humanitarian Data Exchange: El Salvador Waterways (accessed on May 4, 2020).

${ }^{61}$ The map of the roads in El Salvador can be accessed here: Humanitarian Data Exchange: El Salvador Roads (accessed on May 4, 2020).

${ }^{62}$ The elevation map for El Salvador can be accessed here: CGIAR-CSI (accessed on May 4, 2020).

${ }^{63}$ The data on tree coverage for El Salvador can be accessed here: Global Forest Watch (accessed on May 4, 2020).
} 
raster file presents the share of territory covered by trees in each 30 meter $\times 30$ meter grid cell. For each of the census tracts from the 2007 census, we calculate the average level of tree coverage inside of the census tract.

High school exam scores.-The data on the schools' average high school exit exam scores (Prueba de Aprendizaje y Aptitudes para Egresados de Educación Media, PAES) come from the Ministry of Education. PAES results are reported for math, natural sciences, social sciences, and Spanish language and literature. The data cover the period from 1999 to 2017, but exclude the results for 2002-2004 because in those year the Ministry of Education applied a non-disclosed curve to the test scores, preventing comparison with the other years.

2020 survey. - In 2020, we conducted a survey of 1,957 individuals in San Salvador to evaluate the extent of gang-related extortion in gang and non-gang areas. The survey followed the same procedure as the 2019 survey, except that it was conducted over the telephone. The main reason for conducting the survey over the telephone is that, in in-person interviews, extortionrelated questions could have potentially endangered the enumerators. At the beginning of the survey, the enumerators asked the respondents for their address, and the survey proceeded if the address was in one of the census segments randomly chosen in the sampling procedure.

2005 economic census. - The microdata for the 2005 economic census was provided by DIGESTYC. ${ }^{64}$ After creating a registry of all formal and informal firms in the country, DIGESTYC took a random sample of all the firms to ask a long-form questionnaire on income sources, production and remuneration costs, the year the firm was established, etc. From these questions, DIGESTYC calculated the firms' revenue and costs. In total, the registry includes 179,817 firms across the country, while the long-form questionnaire covers 46,864 firms (26\%). In the analysis, we focus on the long-form questionnaire firms based in San Salvador (6,120 firms).

Locations of schools, hospitals, and other establishments.-The data on the locations of schools, hospitals, and other establishments in San Salvador come from Google Maps. ${ }^{65}$ In August 2019, we scraped the data from Google Maps to identify all the establishments in San Salvador. In total, we obtained a dataset with 7,732 establishments. For each observation, Google provides a classification of the type of establishment (e.g., school, hospital, pharmacy, etc.).

Housing rent.-To obtain information on housing rent, in August-September 2018, we scraped

\footnotetext{
${ }^{64}$ Although the census was carried out in 2005, the reference year for all the questions was 2004.

${ }^{65}$ We use the data on the locations of schools and hospitals from Google Maps instead of government records. The primary reason is the accuracy of the data. For instance, in the shapefile the government has provided to us, some of the schools are located outside of El Salvador. However, if we use the data from government records, the results are qualatively very similar.
} 
the data from the most popular website for rent listings in El Salvador, OLX. ${ }^{66}$ We focused on non-commercial listings in which the entire apartment was being rented out (i.e., not a room in the apartment). The listings included the data on the latitude and longitude of the location, the rent requested by the landlord, as well as information about the apartment such as the number of bedrooms, the number of bathrooms, the number of square meters, and whether the apartment is being rented out by an agency. In total, the dataset contains 1,537 observations.

It should be noted that we cannot observe whether a particular apartment was rented out or not. However, after two months, the vast majority of offers were no longer available.

It should also be noted that, on average, the properties listed on OLX are larger and more expensive than the overall pool of properties in San Salvador. In particular, many of the cheapest properties may be rented out on the informal market and are not listed online. If there are more such properties in gang-controlled neighborhoods, our estimates would provide a lower bound on the actual drop in housing rent at the boundary of gang territory.

Nighttime light density. - Annual data on nighttime light density (or luminosity) come from the Defense Meteorological Satellite Program-Operational Linescan System (DMSP-OLS) and spans the period from 1992 to $2013 .{ }^{67}$ In particular, we use the DMSP-OLS data, representing the average stable lights from cities, towns, and other sites with persistent lighting. The data are provided by the National Centers for Environmental Information (NCEI). If for a particular year, the data were available from more than one satellite, we take the average of the two.

Notably, the resolution of the data on nighttime light density is 30 arc seconds $\times 30$ arc seconds (i.e., approximately 1 kilometer $\times 1$ kilometer). Therefore, the data are not sufficiently precise to be used in the regression discontinuity design.

Gang leaders' municipalities of birth.-The data on the gang leaders' municipalities of birth come from El Faro, an investigative newspaper. We use the data from their investigative reports, focusing on the gang leaders who were deported from the United States and had been later convicted for committing crimes in El Salvador. Overall, the sample consists of 33 gang leaders both from MS-13 and 18th Street. We then manually match the names of the gang leaders and the crimes they commited to the criminal records from the Ministry of Justice and Public Security of El Salvador, which contain information on the offendent's municipality of birth.

\footnotetext{
${ }^{66}$ The Salvadoran version of the website can be accessed here: OLX.

${ }^{67}$ The data and a detailed description of it are available here: DMSP-OLS (accessed on May 4, 2020).
} 


\section{A.2. Further details about the primary data sources}

Extortion.-Our measures on firm and household extortion payments draw from three sources. First, the data on whether firms have experienced extortion come from a survey of small and medium-sized enterprises conducted by the Salvadoran Foundation for Economic and Social Development (Fundación Salvadoreña para el Desarrollo Económico y Social, FUSADES). The survey also asked whether the firm has witnessed gang activity in the location where it operates. The survey took place in 2015 and includes data on 512 firms in San Salvador.

Second, the data on the amount of extortion paid to the gangs come from confidential internal records on all the extortion payments that a large Salvadoran distribution firm has made to the gangs between 2012 and 2019. ${ }^{68}$ The firm operates throughout San Salvador municipality and has had to pay extortion in all parts of the municipality. The data consist of 4,120 observations representing the amount of money paid to the gangs and the exact geocoordinates of the location where the payment was made. All the payments are relatively small in size, ranging between $\$ 1$ and $\$ 100$ with the mean of $\$ 6$, and are paid on a day-to-day basis. Almost $97 \%$ of the payments fall into the range from $\$ 1$ to $\$ 20$.

Finally, the data on instances and the amount of extortion paid by individuals come from our own geocoded survey that we conducted in San Salvador in 2020. Specifically, we asked the respondents whether they had ever been extorted and the amount of extortion they had to pay. ${ }^{69}$ The design of the 2020 survey was exactly the same as the one for the 2019 survey, except that it was conducted over the telephone, which happened for two reasons. ${ }^{70}$ First, we would not have been able to ask questions about extortion in in-person interviews because that would have posed a significant risk to the safety of the enumerators. Second, the lockdown restrictions due to the COVID-19 pandemic made it very difficult to conduct in-person interviews.

2019 survey.-For the 2019 survey, the following sampling procedure was applied. Given the uncertainty about their treatment status, census tracts within 15 meters of the boundary of gang territory were excluded from the analysis. Then, separately for places inside and outside of gang territory, we split the census tracts into 30 meter bins, denoting the distance to the

\footnotetext{
${ }^{68}$ These data were shared with us as part of a confidentiality agreement with the firm. We do not name the firm because of security concerns. For further details, see Brown et al. (2020).

${ }^{69}$ More specifically, to account for the possibility of multiple payments, the respondents were asked to name the amount of money paid to the gangs during the month when they faced extortion. We then divide this number by 30 to make it correspond to day-to-day payments.

${ }^{70}$ Before conducting the survey, we verified the respondent's address to ensure that the observations are correctly geocoded. Further details about the survey can be found in the Appendix.
} 
boundary (i.e., 15-44 meters to the boundary, etc.). After that we randomly selected 10 census tracts from each bin and surveyed 8-10 people in each of them. ${ }^{71}$ If there were fewer that 10 census tracts in that bin, we surveyed individuals in all the census tracts that were available. In total, the survey includes 2,314 respondents.

To ensure the safety of the enumerators, if the survey team was denied entry into some of the gang-controlled neighborhoods, those census tracts were replaced by other ones from the same bin. If it was not possible to interview 10 individuals in a census tract (e.g., because after repeated attempts nobody answered the door), additional people were interviewed in other census tracts in the same bin.

Gang boundaries.-The map of gang-controlled neighborhoods that we use in this study is based on data from 2015. To the best of our knowledge, maps of gang-controlled areas for earlier years are nonexistent. However, according to multiple sources in the police department as well as conversations with the local population, the boundaries of gang territory in San Salvador have remained stable since the late 1990s and early 2000s when the police managed to prevent the gangs from expanding their influence over new territories. This stability of the boundaries is consistent with the fact that, while the police managed to stop the expansion of the gangs' influence, it is still unable to regain control over those locations. If changes to the boundaries do occur, it tends to be a product of turf wars (i.e., MS-13 and 18th Street taking over each other's territory); not because of the state regaining control over gang territories or the other way round.

The data on the gang-controlled neighborhoods in San Salvador come from EDH and are presented in Figure 1. However, to accurately calculate distance to the boundary of gang territory, we also complement these data with confidential maps from the police on the gangcontrolled neighborhoods outside of San Salvador municipality. Since the regression discontinuity design focuses on the census tracts inside of San Salvador, this never affects the treatment status of the census tract (i.e., whether or not it is located inside of gang territory). However, for the locations outside of gang territory, it does sometimes affect the distance from them to the boundary of gang territory (i.e., if that location is closer to a gang-controlled location outside of San Salvador). It should be noted that, even with the extended map of gang territory, we are unable to perform the regression discontinuity design outside of San Salvador because the map additionally includes only a small number of locations in the Greater San Salvador area.

\footnotetext{
${ }^{71}$ In areas within 250 meters of the boundary, we surveyed 10 individuals per census tract. In locations further away from the boundary, we surveyed 8 individuals per census tract.
} 
1992 and 2007 censal cartography. - It should be noted that the boundaries of the census tracts in the 1992 and 2007 censuses were not the same. Therefore, we are not able to perform a difference-in-differences analysis at the level of the census tracts. However, in both cases, the size of the census tracts was quite similar, allowing us to accurately measure the distance from the census tract to the boundary of gang territory. Thus, the distance between a particular location and the boundary of gang territory is very similar, regardless of whether we use the 2007 or 1992 census tracts.

It should also be noted that, although DIGESTYC digitized a map the 1992 census tracts, it did not fully finish that work. Specifically, the 1992 map does not have the boundaries of $18.9 \%$ of the census tracts in northwestern San Salvador. However, the vast majority of those neighborhoods are located more than 420 meters away from gang territory and, therefore, would not be included in the analysis in any case. In particular, nearly all of gang territory (except for a few small "islands") and the neighborhoods right next to it are included in the 1992 map. Thus, it is highly unlikely that our estimates would change if all the census tracts were included. ${ }^{72}$

\section{B. DIFFERENCE-IN-DIFFERENCES ANALYSIS}

In this section of the Appendix, we use data for all of El Salvador to perform a differencein-differences analysis, comparing the evolution of nighttime light density in areas that were more and less exposed to gang activity after 1996. This analysis complements the findings from the regression discontinuity design in the following ways. First, it allows us to show that gangs have affected socioeconomic development not only in San Salvador but also in other part parts of El Salvador. Second, since the data on nighttime light density are available for all the years from 1992 to 2013, we are able to confirm that the divergence in the rates of luminosity growth occurred right after the gang members were deported from the United States to El Salvador. In particular, between 1992 and 1996, locations that would later have different levels of gang presence experienced the same growth in luminosity. Finally, since the data on nighttime light density are collected via satellite from space, unlike survey data, these data cannot be selectively under-reported or misreported (e.g., if individuals want to evade taxation by the gangs). ${ }^{73}$

\footnotetext{
${ }^{72}$ DIGESTYC also told us that the work on digitizing the map of the census tracts had to stop because of the lack of funding and that there was no specific reason why some census tracts were digitized and some were not.

${ }^{73}$ It should be noted that the resolution of the nighttime light density data is not sufficiently fine for us to be able to use the maps of gang-controlled neighborhoods in San Salvador and perform a spatial regression discontinuity design with nighttime light density as the outcome variable.
} 


\section{B.1. Empirical strategy}

We perform a difference-in-differences analysis that exploits two sources of variation: the timing of the deportation of the gang members from the United States-which led to the emergence of gangs in El Salvador-and the geographic differences in exposure to organized crime. Our hypothesis is that prior to 1996-the year when the first wave of deportations from the United States took place-locations that would later have different levels of gang activity experienced similar rates of economic development. At the same time, after 1996, we expect to see higher rates of growth in areas with low levels of organized crime.

Unlike for San Salvador, at the national level, a map of gang-controlled areas is not available. Instead, we proxy exposure to gang activity at the national level by the presence of homicides committed by the gangs. ${ }^{74}$ Specifically, we use geocoded data for the exact locations of the gang-related homicides in 2003-2004, the earliest years for which the data are available. We then divide the map of El Salvador into grid squares of approximately 5 by 5 kilometers and calculate the distance from each grid square to the nearest homicide. ${ }^{75}$ A grid cell is assumed to have gang presence if a person was killed by a gang member within the boundaries of that cell.

This definition of gang presence is different from the one used in the regression discontinuity design. In the latter, we use the term "gang territory" to refer to locations where the gangs have territorial control over the area. In the difference-in-difference analysis, we, instead, use the term "gang presence" to refer to larger locations (i.e., grid squares or municipalities) where gangs are known to be active. This second definition is strictly broader than the first one because both MS-13 and 18th Street are active in parts of the country that they do not control. For instance, in Table 7, we document that in San Salvador, the gangs are active not only in their territory but also in neighboring non-gang areas.

Thus, the difference-in-differences estimates should be interpreted as documenting the difference between areas with no gang presence and places with at least some gang presence, whereas the regression discontinuity estimates present the difference between neighborhoods with gang territorial control and locations without gang territorial control but some gang presence. Consequently, the mechanisms behind the difference-in-differences results may also be different from those we document in Section 5. For instance, while in Section 5 we show that

\footnotetext{
${ }^{74}$ Both MS-13 and 18th Street rely on violence not only when fighting for territorial control but also to get extortion payments and enforce contracts, making homicides inherent to most types of gang activity.

${ }^{75}$ The exact size of the grid squares is 0.045 by 0.045 decimal degrees. The results are robust to using grid squares of a different size. To be consistent with the regression discontinuity design, we measure distance in tens of meters.
} 
extortion and other violent crimes are not driving the gaps in living standards in San Salvador, it is plausible that gang-related crimes do play a role in the difference-in-differences analysis. ${ }^{76}$

The outcome variable of interest is nighttime light density (or luminosity) which recent studies have found to be a good proxy for development at the local level (Chen and Nordhaus, 2011; Henderson et al., 2012). In particular, for each of the grid cells, we calculate the average level of luminosity in each of the years from 1992 to 2013. Figure A20 provides a visualization of nighttime light density in 1997, the grid cells, and the locations of the gang-related homicides from 2003-2004.

We then estimate the following event study model (Specification 3) to measure the effect of gang presence on socioeconomic development.

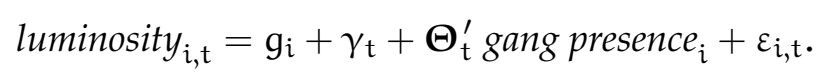

luminosity represents nighttime light density in grid square $i$ at time $t$. The data are in percentage terms, normalized to be equal to 100 percent both in areas with and without gang presence in 1995- the year before the change in the United States immigration policy. gang presence is a dummy for whether grid square $i$ has had a homicide committed by the gangs in 2003-2004; $g_{i}$ and $\gamma_{\mathrm{t}}$ represent grid square and year fixed effects, respectively. Standard errors are clustered by grid square. The coefficients of interest are $\Theta_{t}^{\prime}$, which represent the differences in luminosity growth between locations with and without gang presence.

We also measure the average effect of exposure to gang activity on nighttime light density, by estimating the following model (Specification 4 ).

$$
\text { luminosity }_{i, t}=g_{i}+\gamma_{t}+\Gamma_{i} t+\beta{\text { gang } \text { presence }_{i}} \times \mathbb{1}\{\text { Year }>1997\}_{t}+\varepsilon_{i, t} \text {. }
$$

The main threat to identification is that, as shown in Figure A20, the gangs were primarily attracted to large urban areas, which were already well illuminated and, hence, had less capacity for growth in nighttime light density. Moreover, Figure A21 demonstrates that all locations that in 1995 had luminosity above a certain threshold ended up being exposed to gang activity. To address this concern, in the main specification, we limit the sample of grid cells to those that had below-average nighttime light density in 1995, the year before the change in the United States immigration policy was announced. ${ }^{77}$

\footnotetext{
${ }^{76}$ Given the difference in definitions, the difference-in-differences estimates may suggest that the effect of gang presence is larger or smaller than the regression discontinuity estimates.

${ }^{77}$ When high-luminosity areas are not excluded, as expected, the no pre-trends assumption does not hold: well
} 
In addition, to address the remaining concerns about the identification, we exploit the fact that, after being deported, many gang members who were born in El Salvador returned to their municipality of birth (Sviatschi, 2022b). Thus, we use the birth locations of known gang leaders as an instrumental variable for whether the municipality became exposed to gang activity. ${ }^{78}$ In particular, we estimate Specification (4) at the level of the municipalities instead of the grid cells, using the following equation as the first stage to predict gang presence after 1997.

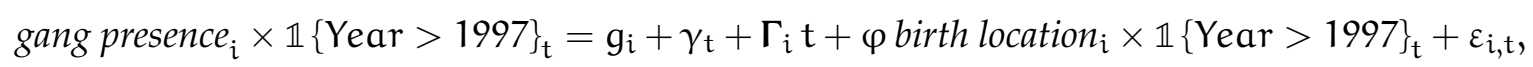

where birth location is a dummy for whether one of the gang leaders was born in this municipality. ${ }^{79}$ The assumption behind this approach is that municipalities where a gang leader was born started experiencing lower rates of luminosity growth after 1997 only because of having a higher probability of being exposed to gang activity.

\section{B.2. Difference-in-differences: Results}

Figure A12 presents the results of estimating the event study model from Specification (3). ${ }^{80}$ It shows that before 1996 locations that became exposed to gang activity had the same growth in nighttime light density as places with no gang presence. This result is particularly important because it complements the findings from the regression discontinuity design, suggesting that between 1992 and 1996 areas with and without gang presence did not have differential rates of economic growth. However, after the gang members were deported from the United States to El Salvador, the grid cells with gang activity experienced significantly lower luminosity growth.

The magnitude of the effect is quite large. By 2010, thirteen years after the deportations, areas with high gang presence had experienced nearly 120 percentage points lower growth in nighttime light density than places with low gang presence. According to Henderson et al. (2012), a one percentage point change in luminosity corresponds to a 0.28 percentage point change in GDP. Thus, in 1998-2010, areas with low gang activity had approximately $120 \times 0.28=$

illuminated locations were already experiencing lower growth in luminosity before the arrival of the gangs.

${ }^{78}$ The data are only available at the level of the municipality; the precise addresses of birth are not available.

${ }^{79} \mathrm{At}$ the municipality level, the data on gang-related homicides are also available for 2000 . Therefore, in addition to using the data for 2003-2004 (i.e., like in the grid-level analysis), we define a municipality to have gang presence if it had a gang-related homicide in 2000. The results are robust to using data only for 2003-2004.

${ }^{80}$ The regression coefficients are reported in Table A3 in the Appendix, which also replicates the results of the event study at the municipality level. 
33.6 percentage points higher growth in GDP than areas with gang presence.

Table A2 presents the results of estimating Specification (4), confirming that after 1996 areas with gang presence experienced lower growth in nighttime light density. It also presents the IV estimates, where exposure to gang activity after 1997 is predicted using a dummy variable for whether one of the gang leaders was born in that municipality, i.e., Specification (5). The first stage coefficients are reported in the lower part of the table, and, as demonstrated by the F-statistic, the instrumental variable accurately predicts exposure to gang activity after 1996. Notably, the results of the IV analysis are very similar to those presented in the OLS regressions, suggesting that the OLS results are not likely to be driven by omitted variable bias.

Overall, the results of the difference-in-differences analysis confirm the findings of the regression discontinuity design, showing that areas with gang presence experienced lower rates of economic growth after 1996. They also confirm the notion that this divergence took place right after the gang members were deported from the United States to El Salvador.

\section{ADDITIONAL INFORMATION AND ROBUSTNESS CHECKS}

\section{C.1. Stability of the boundaries of gang territory}

To the best of our knowledge, the boundaries of gang territory have remained stable throughout the sample period. In particular, we contacted the PNC, inquiring about this issue, and multiple PNC officials confirmed that the boundaries of gang territory had had no significant changes since they were initially formed in the late 1990s and early 2000s. This information has also been confirmed by informal conversations with residents of San Salvador.

To provide additional evidence that the boundaries of gang territory did not change in time, we take advantage of the following fact. As described in Subsection 2.4, both MS-13 and 18th Street consider outsiders a threat to their security. Thus, a disproportionate number of gang-related homicides take place at the boundaries of gang territory (both between the gangs and the state and between the two gangs) because of outsiders attempting to enter gang neighborhoods without permission (Martínez, 2016). Leveraging this fact, we consider geocoded data on all gang-related homicides that were committed in San Salvador in 2003-2014 and split it into two subsamples: those that took place in the first six years of the sample period (2003-2008) and those that took place in the latest six years of the sample period (2009-2014). For each of the homicides, we identify whether it took place in a gang location and calculate the distance to the 
closest boundary of gang territory (either between the gang and the state or between the two gangs). Panel A of Appendix Figure A22 presents the number of gang-related homicides that took place in 2003-2008 by 10-meter bins on either side of the boundary of gang territory; Panel B of Figure A22 provides a similar illustration for gang-related homicides in 2009-2014. In both cases, the number of homicides was particularly high in areas close to the boundaries of the gang neighborhoods from the EDH map, confirming that the map correctly identifies the boundaries of gang territory in the two periods. ${ }^{81}$ In turn, the fact that the highest number of gang-related homicides took place in the same locations both in 2003-2008 and 2009-2014 suggests that the boundaries of gang territory have remained stable during this period.

\section{C.2. Selective migration: Out-of-sample migration}

In Subsection 4.3, we demonstrated that our main results are not driven by selective insample migration: individuals moving to or from gang-controlled neighborhoods, while remaining in San Salvador municipality. Another type of selective migration that can potentially affect the interpretation of our results is out-of-sample migration: individuals moving from San Salvador to a different municipality or abroad. In particular, if rich, educated individuals who initially lived in gang-controlled neighborhoods were more likely to move out of San Salvador than poor and uneducated individuals from the same areas, it could imply that the results in Table 1 are partly determined by this change in the composition of the population. We analyze this mechanism in the following ways.

First, we calculate the rates of selective out-of-sample migration from gang-controlled neighborhoods that would be required to generate the discontinuities from Table 1. For each of the binary household-level characteristics, we define a household to be "rich" if it has that characteristic (e.g., a phone, a computer, etc.) and "poor" if it does not. The only exception is the variable for not having a bathroom, which is defined in the opposite way. Similarly, for each of the individual-level characteristics, we define an individual to be "educated" if they have that characteristic (e.g., a high school degree, a university degree, etc.) and "uneducated" if they do not. We make the conservative assumption that outside of gang territory, the probability of moving out of San Salvador is the same for all individuals and that in gang neighborhoods, poor

\footnotetext{
${ }^{81}$ Notably, as shown in Figure A22, there are multiple gang-related homicides outside of gang territory. We provide a detailed discussion of this fact in Section 5. Also, as we show in Section 4.4, the results in Table 1 are robust to excluding observations from neighborhoods close to the regression discontinuity cutoff (see Table A7). Thus, while the location of the gang-related homicides allows us to validate the boundaries of gang territory from the EDH maps, the results in Table 1 are not driven by areas with the highest numbers of gang-related homicides.
} 
and uneducated individuals migrate out of sample with probability $\beta .{ }^{82}$ Then, for a given $\beta$, we calculate the share of rich households and educated individuals from gang territory that needed to move out of San Salvador to generate the discontinuities for each of the outcome variables.

We use the example of the share of households with a computer to show how these rates were calculated. From the regression output, we get the predicted share of households with a computer for observations zero meters away from the boundary of gang territory, separately for locations inside and outside of gang territory. We denote those numbers as G and NG, respectively. We further denote the number of "rich" households (i.e., those that have a computer) in gang-controlled areas before any migration took place as $x$ and the share of "poor" households (i.e., those that do not have a computer) as $1-\chi$. Next, we assume that a fraction $\alpha$ of the "rich" households and a fraction $\beta$ of the "poor" households migrated out of sample. Thus, in the data, we observe the following relationship.

$$
\frac{(1-\alpha) x}{(1-\alpha) x+(1-\beta)(1-x)}=G
$$

Then, assuming different values of $\beta$, we calculate the value of $\alpha$ that would make this relationship hold if, in the absence of migration, there would not have been any difference in the outcome variable between gang and non-gang locations (i.e., $x=N G$ ).

Appendix Table A20 presents the results of these calculations for $\beta$ equal to $0 \%, 10 \%$, and $20 \%$. Even if we unrealistically assume $\beta=0 \%$ (i.e., that poor and uneducated individuals from gang areas do not have a chance to move out of San Salvador), on average, the rate of out-ofsample migration for rich, educated individuals would have to be as high as $51.7 \%$ to generate the discontinuities from Table 1 . For higher values of $\beta$, this rate is even higher.

Can the rate of out-of-sample migration for rich individuals be that high? To address this question, we take advantage of the fact that, until the mid-2010s, international migration of entire families had been very rare. ${ }^{83}$ International migration is expensive: e.g., the costs of migrating from El Salvador to the United States-the most popular destination among Salvadoran migrants-are approximately $\$ 12,500$ (Kulish, 2018). In turn, the average monthly household income in gang territory is only $\$ 300$. Thus, even to send one family member abroad, Salvadoran households have to save up for a very long time, and migration of entire families is incredibly

\footnotetext{
${ }^{82}$ If rich, educated individuals from non-gang areas are more likely to migrate out of sample, that would make the required rates of selective out-of-sample migration from gang territory even higher.

${ }^{83}$ For instance, according to United States Customs and Border Protection, in 2012, the number of apprehensions of individuals in family units constituted less than $3 \%$ of all apprehensions of Salvadoran citizens at the Southwest border of the United States. In previous years, that number was even smaller.
} 
rare. This fact allows us to estimate the rate of out-of-sample migration by considering whether a household has a family member who moved abroad in 1997-2007 (the 2007 census contains this information). In addition, by looking at the correlation between the probability of a family member moving abroad and the first principal component of the household characteristics, we are able to estimate the extent to which individuals from rich households were more likely to migrate out of San Salvador.

Appendix Table A21 presents the results of estimating Specification (1) for the probability of a household having a family member who moved abroad in 1997-2007. On average, only 6\% of the households have a family member who moved abroad, and this rate does not change at the boundary of gang territory. We also find that rich households both inside and outside of gang territory are more likely to have a family member living abroad. However, the correlation between wealth and out-of-sample migration in gang and non-gang areas are not statistically different from one another. Moreover, although rich households are more likely to have a family member who moved abroad, the magnitude of that effect is much smaller than the rates of selective out-of-sample migration from Appendix Table A20 that are required to generate the discontinuities. In gang territory, an increase in the first principal component of the household characteristics from zero to one (i.e., the difference between the poorest and richest household) increases the probability of the household having a family member move abroad by only $7.1 \%$, whereas the estimates from Table A20 suggest that, even under the unrealistic assumption of $\beta=0 \%$, the rate of out-of-sample migration for rich households needs to be at least $51.7 \%$ to explain the discontinuities. Therefore, out-of-sample migration can account for no more than $100 \times 7.1 / 51.7=13.7$ percent of the effects in Table $1 .{ }^{84,85}$

\footnotetext{
${ }^{84} 13.7 \%$ should be interpreted as the upper bound for the share of the results that can be explained by out-ofsample migration for the following reasons. First, the $7.1 \%$ number assumes that there is no selective out-of-sample migration outside of gang territory. If there is selective out-of-sample migration from non-gang areas, as suggested by the results in Table A21, then this number should be lower. Second, it is possible that some households with a family member abroad have increased their wealth because of that fact (e.g., because of receiving remittances). If that is the case, the results from Table A21 would overestimate the probability of individuals from rich households migrating out of sample. Finally, the 50\% number required to generate the discontinuities in Table 1 is calculated under the assumption that poor individuals are unable to migrate out of sample at all. If poor individuals also have a chance of migrating out of sample, this number should be higher.

${ }^{85}$ We also perform a test in the spirit of McCrary (2008) to check whether, at the boundary of gang territory, there is a discontinuous change in population density for various groups of the population. If individuals from gangcontrolled neighborhoods were more likely to move from San Salvador to a different municipality or abroad, we would expect to see a decrease in population density at the boundary of gang territory. The results in Table A22 demonstrate that there are no discontinuous changes in household and population density at the boundary of gang territory. We also find no heterogeneity by age and gender. Moreover, the signs of all the coefficients are positive (albeit not statistically significant), which is consistent with the notion that the gangs restrict individuals' mobility, making it difficult for them to change their place of residence.
} 
Appendix Section C.3 provides a detailed discussion of the reasons preventing people from migrating out of gang-controlled neighborhoods in San Salvador, and the ways in which gangs track down and punish defectors. ${ }^{86}$

\section{C.3. Reasons preventing people from migrating out of gang territory}

This section provides a detailed discussion of the reasons preventing people from migrating out of gang-controlled neighborhoods in San Salvador, and the ways in which gangs track down and punish defectors.

In general, residents of gang territory in San Salvador can migrate to one of three categories of places: (i) another neighborhood in San Salvador, (ii) some other location in El Salvador, or (iii) abroad. We consecutively discuss these three options, explaining the reasons preventing people from choosing each of them.

We begin with considering the option of individuals moving from gang territory to another neighborhood in San Salvador. In Section 4.3 of the paper, we refer to this type of migration as "in-sample migration" and are able to reject that it is driving our results. This type of migration is not common for the following reason. First, while residents of non-gang neighborhoods have higher income, the costs of living outside of gang territory are also higher: in Table A11, we show that residents of non-gang areas have to pay approximately $\$ 200$ more in monthly rent. The average difference in income is larger (approximately \$350), but this difference partly reflects the gap in education and the fact that residents of non-gang neighborhoods have had multiple years to develop their careers and get well-paying jobs. Therefore, in the short run, an individual who moves from a gang-controlled neighborhood outside of gang territory might not experience a sufficient increase in income to offset the additional costs of living.

Second, individuals who move out of gang territory are likely to be labeled as defectors and to provoke retaliation from the gangs. Defectors are a threat to the gangs' security because they can become informants and provide details about the gangs' whereabouts and activities. For this reason, gang members often track down defectors; many end up killed. It is also common for the gangs to hurt or kill the defectors' relatives and friends. For instance, Salvadoran American Susan Cruz, who helps Central American immigrants in the United States, describes the following story of a girl who had to flee from the gangs: "The gang members have gone

\footnotetext{
${ }^{86}$ These results are also consistent with previous findings in Sviatschi (2022b), showing that migration is high in contested areas with high levels of violence and not in areas that are under stable gang control.
} 
to the grandmother's house asking about the girl. They've also indicated [that] for the grandmother to be OK, someone is going to have to pay for her safety" (Hackel, 2016). Even when people manage to escape themselves, "they have survivor's guilt when other relatives are left behind and are still facing threats of violence" (Hackel, 2016). Thus, unless a resident of gang territory is confident that they and their family and friends would be able to avoid detection by the gangs, as well as getting well-paying jobs that would offset the additional living expenses, it would not be optimal for them to move to a different part of San Salvador.

Could it be optimal for residents of gang territory to leave San Salvador and move to a different part of El Salvador? Such a move is unlikely to be beneficial for the following reasons. All the large cities in El Salvador have a significant gang presence. Thus, unless an individual is willing to move from San Salvador to a remote part of the country, they cannot fully avoid contact with the gangs. One individual describes the situation in the following way: "Where can we go? There are gangs everywhere in the country. [...] What are we going to tell gang members if they see us in a new place and ask where we are coming from? If they are from the same gang as in the place where we used to live, they will not like it [i.e., that we moved]. If they are from a rival gang, they won't like us being there" (Martínez, 2015). In turn, remote parts of the country, where the gangs are less likely to find a person, have even fewer jobs and lower income than in gang-controlled neighborhoods in the large cities. At the same time, a defector and their family and friends would still be at risk of being tracked down by the gangs. Overall, internal migration seldom provides a permanent solution to people fleeing from the gangs. The director of El Salvador's Ministry of Justice and Public Security's victim's unit confirms this fact: “They can try to leave their municipalities, but, often, the gangs will find them" (Sieff, 2018).

How do the gangs manage to track people in other parts of the country? First, it should be noted that El Salvador is a small country with the population of only 6 million people and the territory of 21,041 square kilometers. At the same time, the government estimates that the gangs have approximately 60,000 active members and a support base (i.e., family, collaborators, etc.) of 500,000 - $8 \%$ of El Salvador's population, which are not concentrated in one region (e.g., San Salvador) but spread out throughout the country via a system of cliques (ICG, 2017; Zaidi, 2019). Each clique is integrated into one of the two main gangs, allowing gangs to communicate and distribute information via phone or social networks. If an individual leaves gang territory without permission, gang members have been known to circulate the picture of the defector to all the cliques around the country, adding the person to the "wanted" list (Martínez, 2015; 
Martínez, 2017). Gang members also use the defectors' cellphone numbers and social media posts to find where they are located; they sometimes even post missing person advertisements in newspapers, posing as the friends or relatives of the defector (Valencia Caravantes and Alvarado, 2014; Hackel, 2016; Martínez, 2017; Mackey, 2018). The gangs also take advantage of the fact that Salvadoran ID cards have the address of the individual printed on them. Therefore, when an unknown individual arrives to a neighborhood (not necessarily a gang-controlled neighborhood), the gangs often check the person's ID to perform a background check and see where that person is coming from (Internal Displacement Monitoring Centre, 2018; Immigration and Refugee Board of Canada, 2016). A report by the Internal Displacement Monitoring Centre (2018) describes the gangs' ability to find defectors in the following way: "New arrivals in an area will be checked out, asked where they used to live and asked for their ID card, which bears their address. Given the small size of the country and gangs' extensive surveillance networks, people can often be located within 24 hours. Gang members may even be informed and waiting when internally displaced people (IDP) arrive. Some IDPs have been killed when they are found, and others have been prevented from renting a place to live. Some have moved and been sought out four or five times." Other sources provide a similar assessment of the surveillance and security systems the gangs' have developed in El Salvador (Martínez, 2014; Clavel, 2017; Mackey, 2018).

The only durable solution of escaping gang control implies emigrating from El Salvador, although even this solution also has its caveats. For instance, both MS-13 and 18th Street have a significant presence not only in El Salvador but also in neighboring Honduras and Guatemala. In some rare cases, the gangs have also been able to track defectors in Mexico and even in the United States (Vázquez Ruiz, 2019; Fredrick and Volpe, 2017; Blitzer, 2017). In the course of our work, we spoke to officers at the International Organization for Migration (IOM), and they expressed the view that the fear of being tracked by the gangs (justifiable or not) is an important factor limiting even international migration. However, plausibly the more binding factors affecting international migration are the following. The first one is that most developed countriesmost notably, the United States-have not been willing to accept a large number of migrants from Central America's Northern Triangle (Honduras and Guatemala are experiencing similar gang-related problems). Therefore, even if an individual were to migrate out of El Salvador, they would face the risk of being deported and ending up in the hands of the gangs. The second important factor limiting international migration is related to its costs. The average monthly 
income in gang territory is approximately $\$ 300$, whereas international travel is expensive. This is the reason why until the mid-2010s migration of entire families from El Salvador has been extremely rare (less than $3 \%$ of all migrants). Instead, families saved up money to send one member of the household abroad. In Section 4.3 of the paper, we take advantage of this fact to estimate whether out-of-sample migration can be driving our results. We find that, wealthier households have a higher probability of having a family member abroad. However, we find that this is equally true for wealthier households in neighborhoods not controlled by gangs, likely because, although gangs do not control those areas, they are still active there (as we document in Section 5). Thus, most families that can afford it, try to send a family member away, regardless of whether they live in a gang-controlled neighborhood or not. In addition, we show that the share of wealthier families with a family member abroad is too small to be driving the results. At most, selective out-of-sample migration can explain $14.2 \%$ of the gaps in Table 1.

\section{C.4. Occupational structure and hours worked}

We show that the differences in socioeconomic development in Table 1 cannot be explained by higher levels of unemployment in gang-controlled neighborhoods. In particular, we estimate Specification (1) for the variables from the 2007 census, focusing on the subsample of employed individuals (i.e., individuals who were in employment the week before the census). ${ }^{87}$ Table A24 in the Appendix presents the results. If anything, the differences in socioeconomic conditions are even larger for employed individuals than for the full sample. ${ }^{88}$ These findings are consistent with the notion that due to restrictions on their mobility, residents of gang-controlled neighborhoods are often unable to get well-paying jobs in large firms.

We also demonstrate that the differences in socioeconomic development cannot be explained by higher levels of informal employment in gang territory. Table A25 in the Appendix presents the results of estimating Specification (1) for the variables from the 2007 census, focusing on the subsample of formally employed individuals, which excludes domestic employees, unpaid workers, and self-employed individuals. For all the outcome variables, the discontinuities remain large and statistically significant.

In addition, we use the data from the 2019 survey to document that there are no underlying

\footnotetext{
${ }^{87}$ For the household characteristics, we consider the employment status of the head of the household.

${ }^{88}$ Notably, there is no discontinuity in the probability of being employed. The results of estimating Specification (1) suggest that residents of gang territory are only 0.4 percentage points less likely to be employed than individuals from non-gang areas with the standard error of 1.1 percentage points.
} 
differences in the number of hours worked or in the individuals' willingness to work. In the survey, the respondents were asked to name the number of hours that they currently work as well as the number of hours they would choose to work if offered an hourly wage of $\$ 5, \$ 10$, and \$20. Table A26 in the Appendix presents the results of estimating Specification (1) for these outcome variables, showing that individuals on boths sides of the boundary of gang territory work the same number of hours and have similar willingness to work.

\section{ONLINE APPENDIX REFERENCES}

Blitzer, J. (2017), “The Teens Trapped Between a Gang and the Law”, The New Yorker.

Clavel, T. (2017), “Why It's So Hard to Leave El Salvador's Gangs: An Interview With José Miguel Cruz", InSight Crime.

FREDRICK, J. and VOLPE D. (2017), "As gangs target relatives, a Central American family flees", United Nations High Commissioner for Refugees (UNHCR/ACNUR).

HACKEL, J. (2016), "Salvadoran gangs use Facebook to track down victims", The World.

IMMIGRATION AND REFUGEE BOARD OF CANADA (2016), “El Salvador: Information Gathering Mission Report - Part 1. Gangs in El Salvador and the Situation of Witnesses of Crime and Corruption", Immigration and Refugee Board of Canada.

Internal Displacement Monitoring Centre (2018), “An Atomised Crisis. Reframing displacement caused by crime and violence in El Salvador", Internal Displacement Monitoring Centre (IDMC).

International CRisis Group (2017), “El Salvador's Politics of Perpetual Violence”, Latin America Report №64.

MACKeY, D. (2018), “A Boundless Battlefield. What Happens When a Barrio 18 Soldier Tries to Leave the Gang", The Intercept.

MARTíneZ, Ó. (2014), “The Deadly, Invisible Borders Inside El Salvador”, The New Republic.

Martínez, Ó. (2015), “Huir de las pandillas ante la mirada de la Policía Antipandillas”, El Faro.

MartíneZ, Ó. (2016), “Driving Across the Borders of El Salvador's Gang Territory”, Tech. rep., Insight Crime.

MARTínez, Ó. (2017), “Escaping death, asylum seekers surge in Mexico”, El Faro.

SIEFF, K. (2018), "A month after asylum-seeker's return to El Salvador, a gang made good on death threats", Chicago Tribune.

Valencia Caravantes, D. and Alvarado J. (2014), “La región de los que huyen”, El Faro.

VÁzQuez RuIZ, M. (2019), “Ya no quiero ser perseguido por pandilleros”, United Nations High Commissioner for Refugees (UNHCR/ACNUR). 
ZAIDI, T. (2019), “A Nation Held Hostage”, Foreign Policy. 


\section{TABLES}

Table A1: Summary statistics of the variables used in the estimation

\begin{tabular}{|c|c|c|c|c|}
\hline & Mean & SD & Observations & Source \\
\hline \multicolumn{5}{|l|}{ Panel A: 2007 census } \\
\hline Walls made of concrete, 2007 & 0.932 & 0.252 & 72,252 & 2007 census \\
\hline Bare floor, 2007 & 0.028 & 0.165 & 60,820 & 2007 census \\
\hline Has sewerage infrastructure, 2007 & 0.941 & 0.236 & 62,316 & 2007 census \\
\hline Use electricity for lighting \& cooking, 2007 & 0.108 & 0.311 & 62,316 & 2007 census \\
\hline No bathroom, 2007 & 0.005 & 0.069 & 62,316 & 2007 census \\
\hline Has internet, 2007 & 0.180 & 0.384 & 59,917 & 2007 census \\
\hline Has a motocycle, 2007 & 0.033 & 0.180 & 59,237 & 2007 census \\
\hline Has a car, 2007 & 0.428 & 0.495 & 60,186 & 2007 census \\
\hline Has a phone, 2007 & 0.696 & 0.460 & 60,309 & 2007 census \\
\hline Has a TV, 2007 & 0.952 & 0.214 & 60,525 & 2007 census \\
\hline Has a computer, 2007 & 0.346 & 0.476 & 60,161 & 2007 census \\
\hline Number of rooms, 2007 & 3.089 & 1.649 & 62,316 & 2007 census \\
\hline Can read and write, 2007 & 0.928 & 0.259 & 208,913 & 2007 census \\
\hline Has high school degree, 2007 & 0.448 & 0.497 & 203,423 & 2007 census \\
\hline Has university degree, 2007 & 0.207 & 0.405 & 203,423 & 2007 census \\
\hline \multicolumn{5}{|l|}{ 1st principal component of the: } \\
\hline Dwelling characteristics, 2007 & 0.952 & 0.176 & 60,820 & 2007 census \\
\hline Household characteristics, 2007 & 0.377 & 0.182 & 58,434 & 2007 census \\
\hline Individual characteristics, 2007 & 0.521 & 0.296 & 203,423 & 2007 census \\
\hline Has always lived in San Salvador, 2007 & 0.767 & 0.422 & 225,467 & 2007 census \\
\hline Household density (per km²), 2007 & 3651.7 & 3381.2 & 477 & 2007 census \\
\hline Population density (per $\left.\mathrm{km}^{2}\right), 2007$ & 13131.6 & 11965.3 & 477 & 2007 census \\
\hline Family member moved abroad, 1997-2007 & 0.061 & 0.239 & 62,316 & 2007 census \\
\hline \multicolumn{5}{|l|}{ Panel B: 1992 census } \\
\hline Walls made of concrete, 1992 & 0.813 & 0.390 & 64,899 & 1992 census \\
\hline Bare floor, 1992 & 0.100 & 0.299 & 64,899 & 1992 census \\
\hline Has sewerage infrastructure, 1992 & 0.816 & 0.388 & 64,899 & 1992 census \\
\hline Use electricity for lighting \& cooking, 1992 & 0.182 & 0.386 & 64,899 & 1992 census \\
\hline No bathroom, 1992 & 0.030 & 0.170 & 64,899 & 1992 census \\
\hline Shared bathroom, 1992 & 0.142 & 0.349 & 64,899 & 1992 census \\
\hline Has a motocycle, 1992 & 0.034 & 0.182 & 64,899 & 1992 census \\
\hline Has a car, 1992 & 0.285 & 0.451 & 64,899 & 1992 census \\
\hline Has a phone, 1992 & 0.320 & 0.467 & 64,899 & 1992 census \\
\hline Has a TV, 1992 & 0.860 & 0.347 & 64,899 & 1992 census \\
\hline Has a blender, 1992 & 0.625 & 0.484 & 64,899 & 1992 census \\
\hline Number of rooms, 1992 & 2.670 & 1.706 & 64,899 & 1992 census \\
\hline
\end{tabular}


Can read and write, 1992

$\begin{array}{lll}0.904 & 0.294 & 234,749\end{array}$

1992 census

Has high school degree, 1992

$0.314 \quad 0.464 \quad 227,281$

1992 census

Has university degree, 1992

$0.112 \quad 0.316 \quad 227,281$

1992 census

1st principal component of the:

Dwelling characteristics, 1992

$\begin{array}{lll}0.863 & 0.301 & 64,899\end{array}$

1992 census

Household characteristics, 1992

$0.525 \quad 0.228$

64,899

1992 census

Individual characteristics, 1992

0.380

0.270

227,281

1992 census

Panel C: 2019 survey

Has high school degree, 2019

Has university degree, 2019

Household income, 2019

Works in a firm with

$\geq 100$ employees, 2019

Works in a firm with

$\geq 200$ employees, 2019

Has always lived in location, 2019

Works in neighborhood where lives, 2019

Works in gang territory, 2019

Has been to Santa Ana, 2019

Has been to the beach, 2019

Freedom of movement in area, 2019

$\begin{array}{ccc}0.508 & 0.500 & 2,275 \\ 0.180 & 0.384 & 2,275 \\ 625.05 & 632.84 & 2,314 \\ 0.169 & 0.375 & 2,071\end{array}$

2019 survey

2019 survey

2019 survey

2019 survey

$0.133 \quad 0.340 \quad 2,071 \quad 2019$ survey

$\begin{array}{lll}0.772 & 0.419 & 2,314\end{array}$

2019 survey

$0.302 \quad 0.459$

2,071

$\begin{array}{lll}0.334 & 0.472 & 1,738\end{array}$

2019 survey

2019 survey

$0.495 \quad 0.500$

2,314

2019 survey

$0.872 \quad 0.335 \quad 2,314$

2019 survey

$0.811 \quad 0.392$

2,314

2019 survey

Satisfaction with availability and quality:

Health services, 2019

4.080

1.815

2,314

2019 survey

Education centers, 2019

$4.696 \quad 1.589$

2,314

2019 survey

Roads, 2019

Electricity service, 2019

$4.263 \quad 1.761$

2,314

2019 survey

$5.873 \quad 1.024$

2,314

2019 survey

Would seek help from informal leader for:

Public goods provision, 2019

$0.220 \quad 0.415$

2,314

2019 survey

$0.090 \quad 0.287$

2,314

2019 survey

0.013

0.115

2,314

2019 survey

Would seek help from nobody for:

Public goods provision, 2019

A security, civil, or legal issue, 2019

0.084

0.277

2,314

2019 survey

0.046

0.209

2,314

2019 survey

A financial problem, 2019

$0.115 \quad 0.319$

2,314

2019 survey

$8.613 \quad 3.098$

2,071

2019 survey

Hours would work for a wage of:

$\$ 5$ per hour, 2019

$\begin{array}{lll}7.596 & 4.223 & 2,314\end{array}$

2019 survey

$\$ 10$ per hour, 2019

$8.280 \quad 2.788$

2,314

2019 survey

\$20 per hour, 2019

$8.245 \quad 2.933$

2,314

2019 survey

Panel D: Incarceration data

Incarcerations per $\mathrm{km}^{2}$ :

All incarcerations, before 1997

$114.59 \quad 117.45$

86

DGCP

Homicide, before 1997

4.670

5.618

86

DGCP 
Robbery, before 1997

Sex crimes, before 1997

Assault, before 1997

Other violent crimes, before 1997
22.64

6.588

20.86

9.711
24.05

10.38

21.82

9.756
86

86

86

86
DGCP

DGCP

DGCP

DGCP

Panel E: Extortion and gang-related crimes

Firm was extorted, 2015

Witnessed gang activity in area, 2015

Amount firm paid in extortion, 2012-2019

Person was extorted, 2020

Amount person paid in extortion, 2020

Gang homicides per km², 2003-2011

Gang homicides per km², 2003-2007

Robberies per km², 2014-2015

$\begin{array}{lll}0.246 & 0.431 & 512\end{array}$

$0.738 \quad 0.440$

$6.226 \quad 7.670$

$0.200 \quad 0.400$

$8.447 \quad 31.06$

$9.241 \quad 9.386$

3.348

26.18

4.221
493

4,120

1,957

252

86

86

86

\section{FUSADES \\ FUSADES \\ Internal firm data \\ 2020 survey \\ 2020 survey \\ $\mathrm{PNC}$ \\ PNC}

Panel F: Education outcomes

Dropout rate, 2005-2017

$\begin{array}{lll}0.020 & 0.042 \quad 3,199\end{array}$

OPAMSS

Exam scores, 1999-2001 \& 2005-2017:

$\begin{array}{llll}\text { Math } & 5.434 & 1.334 & 1,284 \\ \text { Natural sciences } & 5.776 & 1.042 & 1,284 \\ \text { Social sciences } & 6.432 & 0.973 & 1,284 \\ \text { Languages \& literature } & 6.151 & 1.051 & 1,284\end{array}$

Panel G: 2005 census

Firms per $\mathrm{km}^{2}$ :

All firms, 2005

Opened after 1997, 2005

Log of the firm's:

Profits, 2005

Revenue, 2005

Costs, 2005

$\begin{array}{lrrl}234.35 & 222.36 & 156 & 2005 \text { census } \\ 120.56 & 139.68 & 156 & 2005 \text { census } \\ & & & \\ 9.767 & 2.087 & 5,631 & 2005 \text { census } \\ 10.97 & 2.183 & 6,118 & 2005 \text { census } \\ 10.44 & 2.406 & 6,083 & 2005 \text { census }\end{array}$

Panel H: Google Maps

Establishments per $\mathrm{km}^{2}$ :

All establishments, 2019

$129.74 \quad 33.59$

Schools, 2019

5.786

4.385

86

Hospitals, 2019

1.805

2.040

86

Cafes \& restaurants, 2019

9.620

5.217

86

Grocery stores, 2019

5.277

3.706

86

Pharmacies, 2019

1.717

1.943

86

86

PAES

PAES

PAES

PAES

Annual school census

PAES

Panel I: Data on housing rent (OLX)

Housing rent, 2018

Log housing rent, 2018

1 room in apartment, 2018

$\begin{array}{cccc}1008.8 & 614.2 & 1,537 & \text { OLX } \\ 6.731 & 0.653 & 1,537 & \text { OLX } \\ 0.113 & 0.317 & 1,537 & \text { OLX }\end{array}$
Google Maps
Google Maps
Google Maps
Google Maps
Google Maps
Google Maps 
2 rooms in apartment, 2018

$0.187 \quad 0.390$

1,537

OLX

3 rooms in apartment, 2018

0.528

0.499

1,537

OLX

4 rooms in apartment, 2018

0.110

0.312

1,537

OLX

5 rooms in apartment, 2018

0.040

0.197

1,537

OLX

6 rooms in apartment, 2018

0.010

0.102

1,537

OLX

$7+$ rooms in apartment, 2018

0.012

0.108

1,537

OLX

1 bathroom in apartment, 2018

0.157

0.364

1,537

OLX

2 bathrooms in apartment, 2018

0.176

0.381

1,537

OLX

$0.446 \quad 0.497$

1,537

OLX

4 bathrooms in apartment, 2018

0.141

0.348

1,537

OLX

$0.053 \quad 0.224$

1,537

OLX

6 bathrooms in apartment, 2018

0.019

0.136

1,537

OLX

$\begin{array}{lll}0.008 & 0.092 & 1,537\end{array}$

OLX

7+ bathrooms in apartment, 2018

$189.38 \quad 264.65$

1,537

OLX

Rented out by agency, 2018

0.491

1,537

OLX

Panel J: Other RDD variables

Urban territory, 1999
Road density (km per $\mathrm{km}^{2}$ ), 2020

$0.812 \quad 0.298$

477

$17.83 \quad 8.80$

477

Has access to waterway

$0.327 \quad 0.470$

477

Elevation

$720.4 \quad 87.83$

477

Territory used for coffee production

0.028

0.132

477

0.048

0.116

477

NYU Atlas of Urban Expansion

Humanitarian OpenStreetMap

Humanitarian OpenStreetMap

CGIAR SRTM

Ministry of the Environment and Natural Resources

Tree coverage, 2000

Panel K: Difference-in-differences variables

\begin{tabular}{lcccc}
\hline Luminosity (grid level), 1992-2013 & 4.743 & 7.765 & 20,592 & DMSP-OLS \\
Gang presence (grid), 1992-2013 & 0.110 & 0.313 & 20,592 & PNC \\
Luminosity (municipality), 1992-2013 & 10.18 & 14.07 & 2,288 & DMSP-OLS \\
Gang presence (municipality), 1992-2013 & 0.538 & 0.499 & 2,288 & PNC \\
Gang leaders' municipality of birth & 0.163 & 0.370 & 2,288 & El Faro \\
\hline
\end{tabular}


Table A2: Gang presence and nighttime light density

\begin{tabular}{|c|c|c|c|c|c|c|c|c|}
\hline & \multicolumn{8}{|c|}{ Nighttime light density (in percentage points relative to 1995) } \\
\hline & \multicolumn{2}{|c|}{ Grid-level analysis } & \multicolumn{6}{|c|}{ Municipality-level analysis } \\
\hline & $(1)$ & $(2)$ & (3) & (4) & $(5)$ & (6) & (7) & $(8)$ \\
\hline \multicolumn{9}{|l|}{$\mathbb{1}\{$ Year $>1997\} \times$} \\
\hline$\times$ Gang presence & $\begin{array}{c}-19.75 \\
(2.14)^{* * *} \\
{[5.55]^{* * *}}\end{array}$ & $\begin{array}{c}-30.65 \\
(11.64)^{* * * *} \\
{[11.64]^{* * *}}\end{array}$ & $\begin{array}{c}-22.18 \\
(4.00)^{* * *} \\
{[5.12]^{* * *}}\end{array}$ & $\begin{array}{c}-19.59 \\
(4.68)^{* * *} \\
{[4.55]^{* * * *}}\end{array}$ & $\begin{array}{c}-26.22 \\
(5.07)^{* * *} \\
{[5.79]^{* * * *}}\end{array}$ & $\begin{array}{c}-23.50 \\
(9.43)^{* *} \\
{[7.29]^{* * *}}\end{array}$ & & \\
\hline$\times$ Gang leader born in municipality & & & & & & & $\begin{array}{c}-14.47 \\
(3.03)^{* * *} \\
{[3.34]^{* * *}}\end{array}$ & $\begin{array}{c}-14.61 \\
(5.96)^{* *} \\
{[4.56]^{* * *}}\end{array}$ \\
\hline Observations & 20,592 & 14,190 & 2,288 & 1,782 & 2,288 & 1,782 & 2,288 & 1,782 \\
\hline Grid cells/ municipalities & 936 & 645 & 104 & 81 & 104 & 81 & 104 & 81 \\
\hline IV analysis (2SLS) & & & & & $\checkmark$ & $\checkmark$ & & \\
\hline Coefficient for excluded instrument & & & & & $\begin{array}{c}0.552 \\
(0.055)^{* * *} \\
{[0.050]^{* * *}}\end{array}$ & $\begin{array}{c}0.622 \\
(0.058)^{* * *} \\
{[0.045]^{* * *}}\end{array}$ & & \\
\hline F-stat, excluded instrument & & & & & $\begin{array}{l}(100.21) \\
{[121.36]}\end{array}$ & $\begin{array}{l}(113.13) \\
{[189.54]}\end{array}$ & & \\
\hline $\begin{array}{l}\text { Excluding areas with above } \\
\text { average luminosity in } 1995\end{array}$ & & $\checkmark$ & & $\checkmark$ & & $\checkmark$ & & $\checkmark$ \\
\hline
\end{tabular}

Note: ${ }^{* *} \mathrm{p}<0.01,{ }^{* *} \mathrm{p}<0.05,{ }^{*} \mathrm{p}<0.1$. The table presents the results of estimating Specification (4) for nighttime light density, measured in percentage points to the level in 1995, one year before the change in the United States immigration policy. It also presents the results of the IV estimation, where in the first stage gang presence after 1996 is predicted using a dummy for whether there was a gang leader born in that municipality, i.e., Specification (5). In 1995, the outcome variable is equal to 100 percent for both gang and non-gang locations. Omitted controls include year dummies, grid cell or municipality fixed effects, and separate time trends for each grid cell or municipality. Standard errors in parentheses are clustered by grid cell or municipality, depending on the regression specification. Standard errors in brackets are adjusted to allow for spatial correlation within a 50 kilometer radius and 5 temporal lags (Conley correction). The first-stage F-statistics in parentheses correspond to the standard errors clustered by grid cell or municipality; the first-stage F-statistics in brackets-to the Conley standard errors. 
Table A3: Event study for nighttime light density

\begin{tabular}{|c|c|c|}
\hline \multirow[b]{2}{*}{ Unit of observation: } & \multicolumn{2}{|c|}{ Nighttime light density } \\
\hline & Grid cell-year & Municipality-year \\
\hline & (1) & (2) \\
\hline \multicolumn{3}{|l|}{ Gang presence $\times$} \\
\hline$\times$ Year $=1992$ & $\begin{array}{c}-0.25 \\
(13.27)\end{array}$ & $\begin{array}{l}12.73 \\
(8.25)\end{array}$ \\
\hline$\times$ Year $=1993$ & $\begin{array}{l}-9.41 \\
(8.87)\end{array}$ & $\begin{array}{c}1.42 \\
(5.81)\end{array}$ \\
\hline$\times$ Year $=1994$ & $\begin{array}{c}-3.47 \\
(12.83)\end{array}$ & $\begin{array}{l}7.26 \\
(5.46)\end{array}$ \\
\hline$\times$ Year $=1996$ & $\begin{array}{c}-5.72 \\
(12.01)\end{array}$ & $\begin{array}{l}-4.74 \\
(4.30)\end{array}$ \\
\hline$\times$ Year $=1997$ & $\begin{array}{c}1.57 \\
(10.30)\end{array}$ & $\begin{array}{l}-3.20 \\
(4.34)\end{array}$ \\
\hline$\times$ Year $=1998$ & $\begin{array}{l}-47.02^{* * *} \\
(9.15)\end{array}$ & $\begin{array}{c}-17.32^{* * *} \\
(4.97)\end{array}$ \\
\hline$\times$ Year $=1999$ & $\begin{array}{l}-47.36^{* * *} \\
(8.98)\end{array}$ & $\begin{array}{l}-20.78^{* * *} \\
(5.07)\end{array}$ \\
\hline$\times$ Year $=2000$ & $\begin{array}{c}-33.94^{* * *} \\
(11.01)\end{array}$ & $\begin{array}{c}-17.76^{* * *} \\
(5.17)\end{array}$ \\
\hline$\times$ Year $=2001$ & $\begin{array}{l}-44.98^{* * *} \\
(13.10)\end{array}$ & $\begin{array}{l}-28.94^{* * *} \\
(7.36)\end{array}$ \\
\hline$\times$ Year $=2002$ & $\begin{array}{l}-26.00^{*} \\
(13.73)\end{array}$ & $\begin{array}{l}-19.47^{* * *} \\
(7.07)\end{array}$ \\
\hline$\times$ Year $=2003$ & $\begin{array}{l}-30.30^{* * *} \\
(10.41)\end{array}$ & $\begin{array}{l}-14.70^{* * *} \\
(5.20)\end{array}$ \\
\hline$\times$ Year $=2004$ & $\begin{array}{c}-82.10^{* * *} \\
(13.89)\end{array}$ & $\begin{array}{l}-31.56^{* * *} \\
(6.69)\end{array}$ \\
\hline$\times$ Year $=2005$ & $\begin{array}{l}-55.40^{* * *} \\
(12.31)\end{array}$ & $\begin{array}{l}-27.22^{* * *} \\
(6.28)\end{array}$ \\
\hline$\times$ Year $=2006$ & $\begin{array}{l}-71.17^{* * *} \\
(12.67)\end{array}$ & $\begin{array}{l}-30.24^{* * *} \\
(5.85)\end{array}$ \\
\hline$\times$ Year $=2007$ & $\begin{array}{c}-76.05^{* * *} \\
(14.93)\end{array}$ & $\begin{array}{l}-35.15^{* * *} \\
(6.67)\end{array}$ \\
\hline$\times$ Year $=2008$ & $\begin{array}{l}-70.94^{* * *} \\
(15.62)\end{array}$ & $\begin{array}{c}-33.11^{* * *} \\
(7.43)\end{array}$ \\
\hline$\times$ Year $=2009$ & $\begin{array}{c}-64.39^{* * *} \\
(16.80)\end{array}$ & $\begin{array}{c}-32.30^{* * *} \\
(7.80)\end{array}$ \\
\hline$\times$ Year $=2010$ & $\begin{array}{c}-118.08^{* * *} \\
(17.93)\end{array}$ & $\begin{array}{c}-49.80^{* * *} \\
(12.05)\end{array}$ \\
\hline$\times$ Year $=2011$ & $\begin{array}{l}-55.51^{* * *} \\
(18.65)\end{array}$ & $\begin{array}{l}-29.23^{* * *} \\
(8.73)\end{array}$ \\
\hline$\times$ Year $=2012$ & $\begin{array}{l}-79.42^{* * *} \\
(20.68)\end{array}$ & $\begin{array}{c}-16.42 \\
(10.64)\end{array}$ \\
\hline$\times$ Year $=2013$ & $\begin{array}{l}-39.75^{*} \\
(20.95)\end{array}$ & $\begin{array}{l}-19.70^{*} \\
(11.12)\end{array}$ \\
\hline Observations & 14,190 & 1,782 \\
\hline Grid cells/ municipalities & 645 & 81 \\
\hline $\begin{array}{l}\text { Excluding areas with above } \\
\text { average luminosity in } 1995\end{array}$ & $\checkmark$ & $\checkmark$ \\
\hline
\end{tabular}

Note: ${ }^{* * *} \mathrm{p}<0.01,{ }^{* *} \mathrm{p}<0.05,{ }^{*} \mathrm{p}<0.1$. The table presents the results of estimating Specification (3) for nighttime light density, measured in percentage points to the level in 1995, one year before the change in the United States immigration policy. In 1995, the outcome variable is equal to 100 percent for both gang and non-gang locations. Omitted controls include year dummies and grid cell or municipality fixed effects. Standard errors in parentheses are clustered by grid cell or municipality, depending on the regression specification. 
Table A4: Placebo: Effects of major roads that did not define the borders of gang territory

\begin{tabular}{|c|c|c|c|c|c|c|}
\hline & \multicolumn{2}{|c|}{ Dwelling characteristics } & \multicolumn{4}{|c|}{ Household characteristics } \\
\hline & $\begin{array}{l}\text { Walls made } \\
\text { of concrete }\end{array}$ & Bare floor & $\begin{array}{l}\text { Has sewerage } \\
\text { infrastructure }\end{array}$ & $\begin{array}{l}\text { Use electricity for } \\
\text { lighting and cooking }\end{array}$ & No bathroom & Has internet \\
\hline & $(1)$ & $(2)$ & (3) & $(4)$ & (5) & (6) \\
\hline Placebo treatment group & $\begin{array}{c}0.008 \\
(0.027)\end{array}$ & $\begin{array}{c}0.009 \\
(0.014)\end{array}$ & $\begin{array}{l}-0.023 \\
(0.029)\end{array}$ & $\begin{array}{c}0.048 \\
(0.029)\end{array}$ & $\begin{array}{c}0.009 \\
(0.008)\end{array}$ & $\begin{array}{l}0.060 \\
(0.037)\end{array}$ \\
\hline Mean of dep. var. & $\begin{array}{c}0.921 \\
56,402\end{array}$ & $\begin{array}{c}0.028 \\
46.922\end{array}$ & $\begin{array}{c}0.955 \\
48.251\end{array}$ & $\begin{array}{c}0.108 \\
48.251\end{array}$ & $\begin{array}{c}0.006 \\
48.251\end{array}$ & $\begin{array}{c}0.157 \\
46.159\end{array}$ \\
\hline \multirow{3}{*}{ Observations } & \multicolumn{6}{|c|}{ Household characteristics } \\
\hline & Has a motorcycle & Has a car & Has a phone & Has a TV & Has a computer & Number of rooms \\
\hline & (7) & (8) & (9) & (10) & $(11)$ & (12) \\
\hline Placebo treatment group & $\begin{array}{l}-0.002 \\
(0.006)\end{array}$ & $\begin{array}{c}0.065 \\
(0.053)\end{array}$ & $\begin{array}{c}0.015 \\
(0.036)\end{array}$ & $\begin{array}{c}0.001 \\
(0.010)\end{array}$ & $\begin{array}{c}0.055 \\
(0.040)\end{array}$ & $\begin{array}{c}0.100 \\
(0.178)\end{array}$ \\
\hline Mean of dep. var. & 0.034 & 0.357 & 0.644 & 0.947 & 0.290 & 2.934 \\
\hline \multirow[t]{4}{*}{ Observations } & 45,607 & 46,384 & 46,456 & 46,636 & 46,382 & 48,251 \\
\hline & \multicolumn{3}{|c|}{ Individual characteristics } & \multicolumn{3}{|c|}{ 1st principal component of the: } \\
\hline & $\begin{array}{l}\text { Can read } \\
\text { and write }\end{array}$ & $\begin{array}{c}\text { Has a high } \\
\text { school degree }\end{array}$ & $\begin{array}{c}\text { Has a university } \\
\text { degree }\end{array}$ & $\begin{array}{c}\text { Dwelling } \\
\text { characteristics }\end{array}$ & $\begin{array}{c}\text { Household } \\
\text { characteristics }\end{array}$ & $\begin{array}{c}\text { Individual } \\
\text { characteristics }\end{array}$ \\
\hline & (13) & $(14)$ & (15) & $(16)$ & $(17)$ & (18) \\
\hline Placebo treatment group & $\begin{array}{c}0.002 \\
(0.010)\end{array}$ & $\begin{array}{c}0.009 \\
(0.035)\end{array}$ & $\begin{array}{c}0.016 \\
(0.029)\end{array}$ & $\begin{array}{l}-0.001 \\
(0.019)\end{array}$ & $\begin{array}{c}0.025 \\
(0.022)\end{array}$ & $\begin{array}{c}0.009 \\
(0.022)\end{array}$ \\
\hline Mean of dep. var. & 0.921 & 0.406 & 0.171 & 0.947 & 0.354 & 0.494 \\
\hline Observations & 160,594 & 156,439 & 156,439 & 46,922 & 44,924 & 156,439 \\
\hline
\end{tabular}

Note: ${ }^{* *} \mathrm{p}<0.01,{ }^{* *} \mathrm{p}<0.05,{ }^{*} \mathrm{p}<0.1$. The table presents the results of estimating Specification (2), using the locations of major roads that did not contribute to the formation of the boundaries of gang territory as a placebo. All the variables come from the 2007 census. The unit of observation is a dwelling, household, or individual, depending on which characteristics are being considered. In the individual-level regressions, the sample consists of the entire population. Omitted controls include a dummy for gang territory as well as a linear trend in distance to the placebo boundary, separately for locations on each side of the placebo boundary and on each side of the boundary of gang territory. Standard errors in parentheses are clustered by 30 meter bins, denoting the distance to the placebo boundary (separately for each side of the boundary). 
Table A5: Socioeconomic characteristics from the 2019 survey

\begin{tabular}{|c|c|c|c|c|c|}
\hline & $\begin{array}{c}\text { Has a high } \\
\text { school degree }\end{array}$ & $\begin{array}{c}\text { Has a university } \\
\text { degree }\end{array}$ & Household income & $\begin{array}{l}\text { Works in a firm with } \\
\geq 100 \text { employees }\end{array}$ & $\begin{array}{l}\text { Works in a firm with } \\
\geq 200 \text { employees }\end{array}$ \\
\hline & $(1)$ & (2) & (3) & (4) & (5) \\
\hline \multicolumn{6}{|c|}{ Panel A: All survey respondents } \\
\hline Gang territory & $\begin{array}{l}-0.311^{* * *} \\
(0.057)\end{array}$ & $\begin{array}{l}-0.254^{* * *} \\
(0.062)\end{array}$ & $\begin{array}{l}-352.60^{* * *} \\
(112.22)\end{array}$ & $\begin{array}{l}-0.123^{* * *} \\
(0.019)\end{array}$ & $\begin{array}{l}-0.115^{* * *} \\
(0.028)\end{array}$ \\
\hline Mean of dep. var. & 0.508 & 0.180 & 625.0 & 0.169 & 0.133 \\
\hline Observations & 2,275 & 2,275 & 2,314 & 2,071 & 2,071 \\
\hline \multicolumn{6}{|c|}{ Panel B: Respondents who have lived in the same location their entire life } \\
\hline Gang territory & $\begin{array}{l}-0.281^{* * * *} \\
(0.061)\end{array}$ & $\begin{array}{l}-0.173^{* * *} \\
(0.056)\end{array}$ & $\begin{array}{l}-271.05^{* *} \\
(118.14)\end{array}$ & $\begin{array}{l}-0.114^{* * *} \\
(0.033)\end{array}$ & $\begin{array}{l}-0.104^{* *} \\
(0.041)\end{array}$ \\
\hline Mean of dep. var. & 0.474 & 0.149 & 602.3 & 0.155 & 0.123 \\
\hline Observations & 1,757 & 1,757 & 1,787 & 1,589 & 1,589 \\
\hline
\end{tabular}

Note: ${ }^{* * *} \mathrm{p}<0.01,{ }^{* *} \mathrm{p}<0.05,{ }^{*} \mathrm{p}<0.1$. After years of gang control, gang-controlled areas have worse socioeconomic conditions than neighboring areas that were not under the control of gangs. The table presents the results of estimating Specification (1) for the variables from the 2019 survey. Panel A presents the results for the full sample; Panel B—for the subsample of respondents who have always lived in the same location. For household income, the unit of observation is a household; for all the other variables—an individual. Omitted controls include a linear trend in distance to the boundary of gang territory, separately for locations on each side of the boundary. Standard errors in parentheses are clustered by 30 meter bins, denoting the distance to the boundary of gang territory (separately for each side of the boundary). 
Table A6: Socioeconomic conditions after exposure to gang control, subsample of individuals who have always lived in San Salvador

\begin{tabular}{|c|c|c|c|c|c|c|}
\hline & \multicolumn{2}{|c|}{ Dwelling characteristics } & \multicolumn{4}{|c|}{ Household characteristics } \\
\hline & $\begin{array}{l}\text { Walls made } \\
\text { of concrete }\end{array}$ & Bare floor & $\begin{array}{l}\text { Has sewerage } \\
\text { infrastructure }\end{array}$ & $\begin{array}{c}\text { Use electricity for } \\
\text { lighting and cooking }\end{array}$ & No bathroom & Has internet \\
\hline & (1) & $(2)$ & (3) & $(4)$ & (5) & (6) \\
\hline Gang territory & $\begin{array}{c}-0.047^{* * *} \\
(0.015)\end{array}$ & $\begin{array}{l}0.026^{* *} \\
(0.010)\end{array}$ & $\begin{array}{c}-0.058^{* *} \\
(0.023)\end{array}$ & $\begin{array}{c}-0.076^{* * *} \\
(0.019)\end{array}$ & $\begin{array}{c}0.005^{* * *} \\
(0.002)\end{array}$ & $\begin{array}{c}-0.132^{* * *} \\
(0.031)\end{array}$ \\
\hline Mean of dep. var. & 0.932 & 0.028 & 0.934 & 0.105 & 0.005 & 0.178 \\
\hline \multirow[t]{4}{*}{ Observations } & 72,087 & 60,675 & 38,926 & 38,926 & 38,926 & 37,147 \\
\hline & \multicolumn{6}{|c|}{ Household characteristics } \\
\hline & Has a motorcycle & Has a car & Has a phone & Has a TV & Has a computer & Number of rooms \\
\hline & (7) & (8) & (9) & $(10)$ & $(11)$ & $(12)$ \\
\hline Gang territory & $\begin{array}{l}-0.019^{* *} \\
(0.007)\end{array}$ & $\begin{array}{c}-0.225^{* * *} \\
(0.044)\end{array}$ & $\begin{array}{c}-0.145^{* * *} \\
(0.033)\end{array}$ & $\begin{array}{c}-0.024^{* * *} \\
(0.006)\end{array}$ & $\begin{array}{c}-0.179^{* * *} \\
(0.037)\end{array}$ & $\begin{array}{c}-0.734^{* * *} \\
(0.186)\end{array}$ \\
\hline Mean of dep. var. & 0.036 & 0.426 & 0.683 & 0.955 & 0.345 & 3.048 \\
\hline \multirow[t]{4}{*}{ Observations } & 36,679 & 37,328 & 37,414 & 37,542 & 37,292 & 38,926 \\
\hline & \multicolumn{3}{|c|}{ Individual characteristics } & \multicolumn{3}{|c|}{ 1st principal component of the: } \\
\hline & $\begin{array}{l}\text { Can read } \\
\text { and write }\end{array}$ & $\begin{array}{c}\text { Has a high } \\
\text { school degree }\end{array}$ & $\begin{array}{c}\text { Has a university } \\
\text { degree }\end{array}$ & $\begin{array}{c}\text { Dwelling } \\
\text { characteristics }\end{array}$ & $\begin{array}{c}\text { Household } \\
\text { characteristics }\end{array}$ & $\begin{array}{c}\text { Individual } \\
\text { characteristics }\end{array}$ \\
\hline & (13) & (14) & (15) & $(16)$ & $(17)$ & (18) \\
\hline Gang territory & $\begin{array}{c}-0.027^{* * *} \\
(0.006)\end{array}$ & $\begin{array}{c}-0.151^{* * *} \\
(0.029)\end{array}$ & $\begin{array}{c}-0.120^{* * *} \\
(0.028)\end{array}$ & $\begin{array}{c}-0.036^{* * *} \\
(0.012)\end{array}$ & $\begin{array}{c}-0.094^{* * *} \\
(0.019)\end{array}$ & $\begin{array}{c}-0.098^{* * *} \\
(0.020)\end{array}$ \\
\hline Mean of dep. var. & 0.931 & 0.445 & 0.201 & 0.952 & 0.374 & 0.520 \\
\hline Observations & 156,627 & 152,953 & 152,953 & 60,675 & 36,147 & 152,953 \\
\hline
\end{tabular}

Note: ${ }^{* * *} \mathrm{p}<0.01,{ }^{* *} \mathrm{p}<0.05,{ }^{*} \mathrm{p}<0.1$. The table presents the results of estimating Specification (1) for the subsample of individuals who have always lived in San Salvador. For the dwelling characteristics, none of the observations are excluded because all the dwellings have always been located in San Salvador. For the household characteristics, we limit the sample to those observations for which the head of the household has always lived in San Salvador. All the variables come from the 2007 census. The unit of observation is a dwelling, household, or individual, depending on which characteristics are being considered. In the individual-level regressions, the sample consists of the entire population. Omitted controls include a linear trend in distance to the boundary of gang territory, separately for locations on each side of the boundary. Standard errors in parentheses are clustered by 30 meter bins, denoting the distance to the boundary of gang territory (separately for each side of the boundary). 
Table A7: Excluding observations within 100 meters of the boundary of gang territory

\begin{tabular}{|c|c|c|c|c|c|c|}
\hline & \multicolumn{2}{|c|}{ Dwelling characteristics } & \multicolumn{4}{|c|}{ Household characteristics } \\
\hline & $\begin{array}{l}\text { Walls made } \\
\text { of concrete }\end{array}$ & Bare floor & $\begin{array}{l}\text { Has sewerage } \\
\text { infrastructure }\end{array}$ & $\begin{array}{l}\text { Use electricity for } \\
\text { lighting and cooking }\end{array}$ & No bathroom & Has internet \\
\hline & (1) & (2) & (3) & (4) & (5) & (6) \\
\hline Gang territory & $\begin{array}{c}-0.067^{* * *} \\
(0.019)\end{array}$ & $\begin{array}{c}0.054^{* * *} \\
(0.011)\end{array}$ & $\begin{array}{c}-0.092^{* * *} \\
(0.028)\end{array}$ & $\begin{array}{c}-0.101^{* * *} \\
(0.017)\end{array}$ & $\begin{array}{c}0.002 \\
(0.003)\end{array}$ & $\begin{array}{c}-0.176^{* * *} \\
(0.024)\end{array}$ \\
\hline Mean of dep. var. & 0.936 & 0.026 & 0.943 & 0.116 & 0.004 & 0.194 \\
\hline \multirow[t]{4}{*}{ Observations } & 50,183 & 42,287 & 43,258 & 43,258 & 43,258 & 41,726 \\
\hline & \multicolumn{6}{|c|}{ Household characteristics } \\
\hline & Has a motorcycle & Has a car & Has a phone & Has a TV & Has a computer & Number of rooms \\
\hline & (7) & (8) & (9) & (10) & (11) & (12) \\
\hline Gang territory & $\begin{array}{c}-0.032^{* * *} \\
(0.008)\end{array}$ & $\begin{array}{c}-0.288^{* * *} \\
(0.048)\end{array}$ & $\begin{array}{c}-0.204^{* * *} \\
(0.052)\end{array}$ & $\begin{array}{c}-0.036^{* * *} \\
(0.008)\end{array}$ & $\begin{array}{c}-0.239 * * * \\
(0.045)\end{array}$ & $\begin{array}{c}-1.006^{* * *} \\
(0.235)\end{array}$ \\
\hline Mean of dep. var. & 0.034 & 0.456 & 0.708 & 0.954 & 0.362 & 3.179 \\
\hline \multirow[t]{4}{*}{ Observations } & 41,205 & 41,911 & 41,964 & 42,108 & 41,860 & 43,258 \\
\hline & \multicolumn{3}{|c|}{ Individual characteristics } & \multicolumn{3}{|c|}{ 1st principal component of the: } \\
\hline & $\begin{array}{l}\text { Can read } \\
\text { and write }\end{array}$ & $\begin{array}{c}\text { Has a high } \\
\text { school degree }\end{array}$ & $\begin{array}{c}\text { Has a university } \\
\text { degree }\end{array}$ & $\begin{array}{c}\text { Dwelling } \\
\text { characteristics }\end{array}$ & $\begin{array}{c}\text { Household } \\
\text { characteristics }\end{array}$ & $\begin{array}{c}\text { Individual } \\
\text { characteristics }\end{array}$ \\
\hline & (13) & (14) & (15) & (16) & (17) & (18) \\
\hline Gang territory & $\begin{array}{c}-0.040^{* * *} \\
(0.009)\end{array}$ & $\begin{array}{c}-0.208^{* * *} \\
(0.029)\end{array}$ & $\begin{array}{c}-0.163^{* * *} \\
(0.028)\end{array}$ & $\begin{array}{c}-0.058^{* * *} \\
(0.013)\end{array}$ & $\begin{array}{c}-0.126^{* * *} \\
(0.022)\end{array}$ & $\begin{array}{c}-0.136^{* * *} \\
(0.021)\end{array}$ \\
\hline Mean of dep. var. & 0.931 & 0.464 & 0.223 & 0.955 & 0.388 & 0.533 \\
\hline Observations & 144,977 & 141,210 & 141,210 & 42,287 & 40,651 & 141,210 \\
\hline
\end{tabular}

Note: ${ }^{* * *} \mathrm{p}<0.01,{ }^{* *} \mathrm{p}<0.05,{ }^{*} \mathrm{p}<0.1$. The table presents the results of estimating Specification (1) for the variables from the 2007 census after excluding observations within 100 meters of the boundary of gang territory. The unit of observation is a dwelling, household, or individual, depending on which characteristics are being considered. In the individual-level regressions, the sample consists of the entire population. Omitted controls include a linear trend in distance to the boundary of gang territory, separately for locations on each side of the boundary. Standard errors in parentheses are clustered by 30 meter bins, denoting the distance to the boundary of gang territory (separately for each side of the boundary). 
Table A8: Controlling for $300 \times 300$ meter fixed effects

\begin{tabular}{|c|c|c|c|c|c|c|}
\hline & \multicolumn{2}{|c|}{ Dwelling characteristics } & \multicolumn{4}{|c|}{ Household characteristics } \\
\hline & $\begin{array}{l}\text { Walls made } \\
\text { of concrete }\end{array}$ & Bare floor & $\begin{array}{l}\text { Has sewerage } \\
\text { infrastructure }\end{array}$ & $\begin{array}{c}\text { Use electricity for } \\
\text { lighting and cooking }\end{array}$ & No bathroom & Has internet \\
\hline & (1) & (2) & (3) & (4) & (5) & (6) \\
\hline Gang territory & $\begin{array}{l}-0.052^{*} \\
(0.030)\end{array}$ & $\begin{array}{c}0.023^{* * *} \\
(0.007)\end{array}$ & $\begin{array}{c}-0.073^{* * *} \\
(0.026)\end{array}$ & $\begin{array}{c}-0.097^{* * *} \\
(0.025)\end{array}$ & $\begin{array}{c}0.006^{* * *} \\
(0.002)\end{array}$ & $\begin{array}{c}-0.160^{* * *} \\
(0.028)\end{array}$ \\
\hline Mean of dep. var. & 0.932 & 0.028 & 0.941 & 0.108 & 0.005 & 0.180 \\
\hline \multirow[t]{4}{*}{ Observations } & 72,087 & 60,675 & 62,169 & 62,169 & 62,169 & 59,776 \\
\hline & \multicolumn{6}{|c|}{ Household characteristics } \\
\hline & Has a motorcycle & Has a car & Has a phone & Has a TV & Has a computer & Number of rooms \\
\hline & $(7)$ & $(8)$ & (9) & $(10)$ & $(11)$ & $(12)$ \\
\hline Gang territory & $\begin{array}{l}-0.010^{*} \\
(0.006)\end{array}$ & $\begin{array}{l}-0.224^{* * *} \\
(0.047)\end{array}$ & $\begin{array}{c}-0.135^{* * *} \\
(0.032)\end{array}$ & $\begin{array}{l}-0.019 \\
(0.011)\end{array}$ & $\begin{array}{l}-0.190^{* * *} \\
(0.037)\end{array}$ & $\begin{array}{l}-0.641^{* * *} \\
(0.207)\end{array}$ \\
\hline Mean of dep. var. & 0.033 & 0.428 & 0.697 & 0.952 & 0.346 & 3.093 \\
\hline \multirow[t]{4}{*}{ Observations } & 59,096 & 60,045 & 60,168 & 60,384 & 60,020 & 62,169 \\
\hline & \multicolumn{3}{|c|}{ Individual characteristics } & \multicolumn{3}{|c|}{ 1st principal component of the: } \\
\hline & $\begin{array}{l}\text { Can read } \\
\text { and write }\end{array}$ & $\begin{array}{c}\text { Has a high } \\
\text { school degree }\end{array}$ & $\begin{array}{c}\text { Has a university } \\
\text { degree }\end{array}$ & $\begin{array}{c}\text { Dwelling } \\
\text { characteristics }\end{array}$ & $\begin{array}{c}\text { Household } \\
\text { characteristics }\end{array}$ & $\begin{array}{c}\text { Individual } \\
\text { characteristics }\end{array}$ \\
\hline & (13) & (14) & $(15)$ & (16) & $(17)$ & $(18)$ \\
\hline Gang territory & $\begin{array}{l}-0.031^{* * *} \\
(0.006)\end{array}$ & $\begin{array}{l}-0.137^{* * *} \\
(0.031)\end{array}$ & $\begin{array}{l}-0.101^{* * *} \\
(0.032)\end{array}$ & $\begin{array}{l}-0.040^{* *} \\
(0.017)\end{array}$ & $\begin{array}{c}-0.100^{* * *} \\
(0.021)\end{array}$ & $\begin{array}{l}-0.089^{* * *} \\
(0.023)\end{array}$ \\
\hline Mean of dep. var. & 0.928 & 0.449 & 0.208 & 0.952 & 0.378 & 0.522 \\
\hline Observations & 208,416 & 202,935 & 202,935 & 60,675 & 58,293 & 202,935 \\
\hline
\end{tabular}

Note: ${ }^{* *} \mathrm{p}<0.01,{ }^{* *} \mathrm{p}<0.05,{ }^{*} \mathrm{p}<0.1$. The table presents the results of estimating Specification (1) for the variables from the 2007 census, controlling for $300 \times 300$ meter fixed effects. The unit of observation is a dwelling, household, or individual, depending on which characteristics are being considered. In the individual-level regressions, the sample consists of the entire population. Omitted controls include $300 \times 300$ meter fixed effects and a linear trend in distance to the boundary of gang territory, separately for locations on each side of the boundary. Standard errors in parentheses are clustered by 30 meter bins, denoting the distance to the boundary of gang territory (separately for each side of the boundary). 
Table A9: Two-dimensional regression discontinuity in latitude and longitude

\begin{tabular}{|c|c|c|c|c|c|c|}
\hline & \multicolumn{2}{|c|}{ Dwelling characteristics } & \multicolumn{4}{|c|}{ Household characteristics } \\
\hline & $\begin{array}{l}\text { Walls made } \\
\text { of concrete }\end{array}$ & Bare floor & $\begin{array}{l}\text { Has sewerage } \\
\text { infrastructure }\end{array}$ & $\begin{array}{l}\text { Use electricity for } \\
\text { lighting and cooking }\end{array}$ & No bathroom & Has internet \\
\hline & (1) & (2) & (3) & (4) & (5) & (6) \\
\hline Gang territory & $\begin{array}{c}-0.051^{* * *} \\
(0.007)\end{array}$ & $\begin{array}{l}0.009^{*} \\
(0.005)\end{array}$ & $\begin{array}{l}-0.006 \\
(0.015)\end{array}$ & $\begin{array}{c}-0.076^{* * *} \\
(0.008)\end{array}$ & $\begin{array}{c}0.004^{* * *} \\
(0.001)\end{array}$ & $\begin{array}{c}-0.141^{* * *} \\
(0.011)\end{array}$ \\
\hline Mean of dep. var. & 0.932 & 0.028 & 0.941 & 0.108 & 0.005 & 0.181 \\
\hline \multirow[t]{4}{*}{ Observations } & 72,087 & 60,675 & 62,169 & 62,169 & 62,169 & 59,776 \\
\hline & \multicolumn{6}{|c|}{ Household characteristics } \\
\hline & Has a motorcycle & Has a car & Has a phone & Has a TV & Has a computer & Number of rooms \\
\hline & (7) & (8) & (9) & $(10)$ & (11) & (12) \\
\hline Gang territory & $\begin{array}{c}-0.007^{* *} \\
(0.002)\end{array}$ & $\begin{array}{c}-0.256^{* * *} \\
(0.021)\end{array}$ & $\begin{array}{c}-0.175^{* * *} \\
(0.017)\end{array}$ & $\begin{array}{c}-0.024^{* * *} \\
(0.003)\end{array}$ & $\begin{array}{c}-0.199 * * * \\
(0.017)\end{array}$ & $\begin{array}{c}-0.806^{* * *} \\
(0.087)\end{array}$ \\
\hline Mean of dep. var. & 0.033 & 0.429 & 0.697 & 0.952 & 0.346 & 3.093 \\
\hline \multirow[t]{4}{*}{ Observations } & 59,096 & 60,045 & 60,168 & 60,384 & 60,020 & 62,169 \\
\hline & \multicolumn{3}{|c|}{ Individual characteristics } & \multicolumn{3}{|c|}{ 1st principal component of the: } \\
\hline & $\begin{array}{l}\text { Can read } \\
\text { and write }\end{array}$ & $\begin{array}{c}\text { Has a high } \\
\text { school degree }\end{array}$ & $\begin{array}{c}\text { Has a university } \\
\text { degree }\end{array}$ & $\begin{array}{c}\text { Dwelling } \\
\text { characteristics }\end{array}$ & $\begin{array}{c}\text { Household } \\
\text { characteristics }\end{array}$ & $\begin{array}{c}\text { Individual } \\
\text { characteristics }\end{array}$ \\
\hline & (13) & (14) & (15) & $(16)$ & $(17)$ & $(18)$ \\
\hline Gang territory & $\begin{array}{c}-0.026^{* * *} \\
(0.004)\end{array}$ & $\begin{array}{c}-0.161^{* * *} \\
(0.012)\end{array}$ & $\begin{array}{c}-0.141^{* * *} \\
(0.012)\end{array}$ & $\begin{array}{c}-0.028^{* * *} \\
(0.006)\end{array}$ & $\begin{array}{c}-0.104^{* * *} \\
(0.009)\end{array}$ & $\begin{array}{c}-0.109^{* * *} \\
(0.009)\end{array}$ \\
\hline Mean of dep. var. & 0.928 & 0.449 & 0.208 & 0.952 & 0.378 & 0.522 \\
\hline Observations & 208,416 & 202,935 & 202,935 & 60,675 & 58,293 & 202,935 \\
\hline
\end{tabular}

Note: ${ }^{* * *} \mathrm{p}<0.01,{ }^{* *} \mathrm{p}<0.05,{ }^{*} \mathrm{p}<0.1$. The table presents the results of estimating Specification (1) for the variables from the 2007 census, using latitude and longitude as the forcing variables. The unit of observation is a dwelling, household, or individual, depending on which characteristics are being considered. In the individual-level regressions, the sample consists of the entire population. Omitted controls include a linear trend in latitude and longitude (demeaned), separately for locations on each side of the boundary. Standard errors in parentheses are clustered by 30 meter bins, denoting the distance to the boundary of gang territory (separately for each side of the boundary). 
Table A10: Excluding 10\% of the observations with the highest values of the 1st principal components from non-gang areas

\begin{tabular}{|c|c|c|c|c|c|c|}
\hline & \multicolumn{2}{|c|}{ Dwelling characteristics } & \multicolumn{4}{|c|}{ Household characteristics } \\
\hline & $\begin{array}{l}\text { Walls made } \\
\text { of concrete }\end{array}$ & Bare floor & $\begin{array}{l}\text { Has sewerage } \\
\text { infrastructure }\end{array}$ & $\begin{array}{l}\text { Use electricity for } \\
\text { lighting and cooking }\end{array}$ & No bathroom & Has internet \\
\hline & $(1)$ & $(2)$ & (3) & $(4)$ & (5) & (6) \\
\hline Gang territory & $\begin{array}{c}-0.042^{* *} \\
(0.016)\end{array}$ & $\begin{array}{l}0.023^{* *} \\
(0.010)\end{array}$ & $\begin{array}{c}-0.047^{* *} \\
(0.022)\end{array}$ & $\begin{array}{l}-0.031^{*} \\
(0.017)\end{array}$ & $\begin{array}{c}0.005^{* * *} \\
(0.002)\end{array}$ & $\begin{array}{c}-0.064^{* * *} \\
(0.024)\end{array}$ \\
\hline Mean of dep. var. & 0.929 & 0.030 & 0.939 & 0.081 & 0.005 & 0.143 \\
\hline \multirow[t]{4}{*}{ Observations } & 69,008 & 57,596 & 59,569 & 59,569 & 59,569 & 57,176 \\
\hline & \multicolumn{6}{|c|}{ Household characteristics } \\
\hline & Has a motorcycle & Has a car & Has a phone & Has a TV & Has a computer & Number of rooms \\
\hline & (7) & $(8)$ & (9) & $(10)$ & $(11)$ & $(12)$ \\
\hline Gang territory & $\begin{array}{l}-0.002 \\
(0.006)\end{array}$ & $\begin{array}{c}-0.165^{* * *} \\
(0.046)\end{array}$ & $\begin{array}{c}-0.116^{* * *} \\
(0.033)\end{array}$ & $\begin{array}{c}-0.018^{* * *} \\
(0.006)\end{array}$ & $\begin{array}{c}-0.124^{* * *} \\
(0.033)\end{array}$ & $\begin{array}{c}-0.500^{* * *} \\
(0.185)\end{array}$ \\
\hline Mean of dep. var. & 0.028 & 0.402 & 0.682 & 0.950 & 0.316 & 2.980 \\
\hline \multirow[t]{4}{*}{ Observations } & 56,496 & 57,445 & 57,568 & 57,784 & 57,420 & 59,569 \\
\hline & \multicolumn{3}{|c|}{ Individual characteristics } & \multicolumn{3}{|c|}{ 1st principal component of the: } \\
\hline & $\begin{array}{l}\text { Can read } \\
\text { and write }\end{array}$ & $\begin{array}{c}\text { Has a high } \\
\text { school degree }\end{array}$ & $\begin{array}{c}\text { Has a university } \\
\text { degree }\end{array}$ & $\begin{array}{c}\text { Dwelling } \\
\text { characteristics }\end{array}$ & $\begin{array}{c}\text { Household } \\
\text { characteristics }\end{array}$ & $\begin{array}{c}\text { Individual } \\
\text { characteristics }\end{array}$ \\
\hline & (13) & $(14)$ & (15) & $(16)$ & $(17)$ & (18) \\
\hline Gang territory & $\begin{array}{c}-0.026^{* * *} \\
(0.007)\end{array}$ & $\begin{array}{c}-0.103^{* * *} \\
(0.028)\end{array}$ & $\begin{array}{l}-0.040^{*} \\
(0.022)\end{array}$ & $\begin{array}{l}-0.032^{* *} \\
(0.012)\end{array}$ & $\begin{array}{c}-0.057^{* * *} \\
(0.018)\end{array}$ & $\begin{array}{c}-0.055^{* * *} \\
(0.019)\end{array}$ \\
\hline Mean of dep. var. & 0.924 & 0.421 & 0.169 & 0.949 & 0.359 & 0.498 \\
\hline Observations & 199,162 & 193,681 & 193,681 & 57,596 & 55,693 & 193,681 \\
\hline
\end{tabular}

Note: ${ }^{* * *} \mathrm{p}<0.01,{ }^{* *} \mathrm{p}<0.05,{ }^{*} \mathrm{p}<0.1$. The table presents the results of estimating Specification (1) after excluding $10 \%$ of the observations with the highest levels of the first principal component from non-gang areas. For the dwelling characteristics, we use the first principal component of the dwelling characteristics; for the household characteristics-the first principal component of the household characteristics; for the individual characteristics - the first principal component of the individual characteristics. When more than $10 \%$ of observations had the first principal component less than or equal to the value of the 10th percentile, we exclude a random subset of observations for which the first principal component is exactly equal to the 10th percentile. The estimates do not depend on which subsample of observations are excluded. In particular, we perform 1,000 iterations of this procedure, and for each variable report the most concervative results, i.e., when they are least significant. All the variables come from the 2007 census. The unit of observation is a dwelling, household, or individual, depending on which characteristics are being considered. In the individual-level regressions, the sample consists of the entire population. Omitted controls include a linear trend in distance to the boundary of gang territory, separately for locations on each side of the boundary. Standard errors in parentheses are clustered by 30 meter bins, denoting the distance to the boundary of gang territory (separately for each side of the boundary). 
Table A11: Housing rent

\begin{tabular}{|c|c|c|}
\hline & Log of housing rent & Housing rent \\
\hline & $(1)$ & (2) \\
\hline Gang territory & $\begin{array}{c}-0.191^{* * *} \\
(0.052)\end{array}$ & $\begin{array}{c}-203.20^{* * *} \\
(56.33)\end{array}$ \\
\hline \multicolumn{3}{|c|}{ Number of rooms in the apartment: } \\
\hline 2 rooms & $\begin{array}{c}0.210^{* * *} \\
(0.053)\end{array}$ & $\begin{array}{c}19.93 \\
(30.79)\end{array}$ \\
\hline 3 rooms & $\begin{array}{c}0.296^{* * *} \\
(0.059)\end{array}$ & $\begin{array}{l}87.65^{* *} \\
(42.09)\end{array}$ \\
\hline 4 rooms & $\begin{array}{l}0.189^{* *} \\
(0.070)\end{array}$ & $\begin{array}{c}33.14 \\
(73.21)\end{array}$ \\
\hline 5 rooms & $\begin{array}{c}0.134 \\
(0.107)\end{array}$ & $\begin{array}{c}2.46 \\
(124.27)\end{array}$ \\
\hline 6 rooms & $\begin{array}{c}0.383^{* * *} \\
(0.089)\end{array}$ & $\begin{array}{l}330.19^{* *} \\
(148.86)\end{array}$ \\
\hline $7+$ rooms & $\begin{array}{c}0.365^{* * *} \\
(0.124)\end{array}$ & $\begin{array}{l}378.31^{*} \\
(194.71)\end{array}$ \\
\hline \multicolumn{3}{|c|}{ Number of bathrooms in the apartment: } \\
\hline 2 bathrooms & $\begin{array}{c}0.507^{* * *} \\
(0.073)\end{array}$ & $\begin{array}{c}209.67^{* * *} \\
(49.22)\end{array}$ \\
\hline 3 bathrooms & $\begin{array}{c}0.718^{* * *} \\
(0.062)\end{array}$ & $\begin{array}{c}350.97^{* * *} \\
(46.61)\end{array}$ \\
\hline 4 bathrooms & $\begin{array}{c}0.836^{* * *} \\
(0.066)\end{array}$ & $\begin{array}{c}473.41^{* * *} \\
(82.91)\end{array}$ \\
\hline 5 bathrooms & $\begin{array}{c}0.992^{* * *} \\
(0.080)\end{array}$ & $\begin{array}{c}650.37^{* * *} \\
(130.00)\end{array}$ \\
\hline 6 bathrooms & $\begin{array}{c}1.095^{* * *} \\
(0.113)\end{array}$ & $\begin{array}{c}1,028.51^{* * *} \\
(213.85)\end{array}$ \\
\hline $7+$ bathrooms & $\begin{array}{c}0.979 * * * \\
(0.160)\end{array}$ & $\begin{array}{c}786.86^{* * *} \\
(233.44)\end{array}$ \\
\hline Square meters & $\begin{array}{c}0.140^{* * *} \\
(0.018)\end{array}$ & $\begin{array}{c}190.59^{* * * *} \\
(22.68)\end{array}$ \\
\hline Square meters squared & $\begin{array}{c}-0.003^{* * *} \\
(0.000)\end{array}$ & $\begin{array}{c}-4.29^{* * *} \\
(0.61)\end{array}$ \\
\hline Rented out by an agency & $\begin{array}{c}0.269^{* * *} \\
(0.034)\end{array}$ & $\begin{array}{c}242.29^{* * *} \\
(15.55)\end{array}$ \\
\hline Mean dep. var & 6.731 & $1,008.81$ \\
\hline Observations & 1,537 & 1,537 \\
\hline
\end{tabular}

Note: ${ }^{* * *} \mathrm{p}<0.01,{ }^{* *} \mathrm{p}<0.05,{ }^{*} \mathrm{p}<0.1$. The table presents the results of estimating Specification (1) for housing rent requested by landlords, controlling for the characteristics of the apartments that are being rented out. The unit of observation is an apartment. Omitted controls include a linear trend in distance to the boundary of gang territory, separately for locations on each side of the boundary. Standard errors in parentheses are clustered by 30 meter bins, denoting the distance to the boundary of gang territory (separately for each side of the boundary). 
Table A12: Estimating the effects separately for MS-13 and 18th Street

\begin{tabular}{|c|c|c|c|c|c|c|}
\hline & \multicolumn{2}{|c|}{ Dwelling characteristics } & \multicolumn{4}{|c|}{ Household characteristics } \\
\hline & $\begin{array}{l}\text { Walls made } \\
\text { of concrete }\end{array}$ & Bare floor & $\begin{array}{l}\text { Has sewerage } \\
\text { infrastructure }\end{array}$ & $\begin{array}{l}\text { Use electricity for } \\
\text { lighting and cooking }\end{array}$ & No bathroom & Has internet \\
\hline & $(1)$ & $(2)$ & (3) & $(4)$ & (5) & (6) \\
\hline MS-13 & $\begin{array}{c}-0.051^{* * *} \\
(0.017)\end{array}$ & $\begin{array}{l}0.024^{* *} \\
(0.010)\end{array}$ & $\begin{array}{c}-0.058^{* *} \\
(0.025)\end{array}$ & $\begin{array}{c}-0.079^{* * *} \\
(0.021)\end{array}$ & $\begin{array}{c}0.006^{* * *} \\
(0.001)\end{array}$ & $\begin{array}{c}-0.141^{* * *} \\
(0.031)\end{array}$ \\
\hline 18th Street & $\begin{array}{c}-0.044^{* *} \\
(0.017)\end{array}$ & $\begin{array}{l}0.027^{* *} \\
(0.011)\end{array}$ & $\begin{array}{c}-0.045^{* *} \\
(0.021)\end{array}$ & $\begin{array}{c}-0.078^{* * *} \\
(0.022)\end{array}$ & $\begin{array}{l}0.005^{*} \\
(0.003)\end{array}$ & $\begin{array}{c}-0.126^{* * *} \\
(0.031)\end{array}$ \\
\hline Mean of dep. var. & 0.932 & 0.028 & 0.941 & 0.108 & 0.005 & 0.181 \\
\hline \multirow[t]{4}{*}{ Observations } & 72,087 & 60,675 & 62,169 & 62,169 & 62,169 & 59,776 \\
\hline & \multicolumn{6}{|c|}{ Household characteristics } \\
\hline & Has a motorcycle & Has a car & Has a phone & Has a TV & Has a computer & Number of rooms \\
\hline & (7) & (8) & (9) & $(10)$ & $(11)$ & $(12)$ \\
\hline MS-13 & $\begin{array}{c}-0.015^{* *} \\
(0.006)\end{array}$ & $\begin{array}{c}-0.242^{* * *} \\
(0.050)\end{array}$ & $\begin{array}{c}-0.163^{* * *} \\
(0.034)\end{array}$ & $\begin{array}{c}-0.025^{* * *} \\
(0.006)\end{array}$ & $\begin{array}{c}-0.198^{* * *} \\
(0.039)\end{array}$ & $\begin{array}{c}-0.829^{* * *} \\
(0.194)\end{array}$ \\
\hline 18th Street & $\begin{array}{l}-0.012^{*} \\
(0.006)\end{array}$ & $\begin{array}{c}-0.187^{* * *} \\
(0.049)\end{array}$ & $\begin{array}{c}-0.119^{* * *} \\
(0.036)\end{array}$ & $\begin{array}{c}-0.019^{* * *} \\
(0.006)\end{array}$ & $\begin{array}{c}-0.159^{* * *} \\
(0.037)\end{array}$ & $\begin{array}{c}-0.615^{* * *} \\
(0.212)\end{array}$ \\
\hline Mean of dep. var. & 0.033 & 0.429 & 0.697 & 0.952 & 0.346 & 3.093 \\
\hline \multirow[t]{4}{*}{ Observations } & 59,096 & 60,045 & 60,168 & 60,384 & 60,020 & 62,169 \\
\hline & \multicolumn{3}{|c|}{ Individual characteristics } & \multicolumn{3}{|c|}{ 1st principal component of the: } \\
\hline & $\begin{array}{l}\text { Can read } \\
\text { and write }\end{array}$ & $\begin{array}{c}\text { Has a high } \\
\text { school degree }\end{array}$ & $\begin{array}{c}\text { Has a university } \\
\text { degree }\end{array}$ & $\begin{array}{c}\text { Dwelling } \\
\text { characteristics }\end{array}$ & $\begin{array}{c}\text { Household } \\
\text { characteristics }\end{array}$ & $\begin{array}{c}\text { Individual } \\
\text { characteristics }\end{array}$ \\
\hline & (13) & $(14)$ & $(15)$ & $(16)$ & (17) & (18) \\
\hline MS-13 & $\begin{array}{c}-0.036^{* * *} \\
(0.007)\end{array}$ & $\begin{array}{c}-0.179^{* * *} \\
(0.030)\end{array}$ & $\begin{array}{c}-0.145^{* * *} \\
(0.027)\end{array}$ & $\begin{array}{c}-0.036^{* * *} \\
(0.012)\end{array}$ & $\begin{array}{c}-0.102^{* * *} \\
(0.021)\end{array}$ & $\begin{array}{c}-0.119^{* * *} \\
(0.020)\end{array}$ \\
\hline 18th Street & $\begin{array}{c}-0.029^{* * *} \\
(0.008)\end{array}$ & $\begin{array}{c}-0.138^{* * *} \\
(0.031)\end{array}$ & $\begin{array}{c}-0.108^{* * *} \\
(0.027)\end{array}$ & $\begin{array}{c}-0.036^{* *} \\
(0.013)\end{array}$ & $\begin{array}{c}-0.082^{* * *} \\
(0.021)\end{array}$ & $\begin{array}{c}-0.091^{* * *} \\
(0.021)\end{array}$ \\
\hline Mean of dep. var. & 0.928 & 0.449 & 0.208 & 0.952 & 0.378 & 0.522 \\
\hline Observations & 208,416 & 202,935 & 202,935 & 60,675 & 58,293 & 202,935 \\
\hline
\end{tabular}

Note: ${ }^{* * *} \mathrm{p}<0.01,{ }^{* *} \mathrm{p}<0.05,{ }^{*} \mathrm{p}<0.1$. The table presents the results of estimating Specification (1) with the dummy for gang territory replaced with two dummies for areas controlled by MS-13 and areas controlled by 18th Street. All the variables come from the 2007 census. The unit of observation is a dwelling, household, or individual, depending on which characteristics are being considered. In the individual-level regressions, the sample consists of the entire population. Omitted controls include a linear trend in distance to the boundary of gang territory, separately for locations on each side of the boundary. Standard errors in parentheses are clustered by 30 meter bins, denoting the distance to the boundary of gang territory (separately for each side of the boundary). 
Table A13: Excluding areas within 150 meters of the rival gang

\begin{tabular}{|c|c|c|c|c|c|c|}
\hline & \multicolumn{2}{|c|}{ Dwelling characteristics } & \multicolumn{4}{|c|}{ Household characteristics } \\
\hline & $\begin{array}{l}\text { Walls made } \\
\text { of concrete }\end{array}$ & Bare floor & $\begin{array}{l}\text { Has sewerage } \\
\text { infrastructure }\end{array}$ & $\begin{array}{l}\text { Use electricity for } \\
\text { lighting and cooking }\end{array}$ & No bathroom & Has internet \\
\hline & (1) & (2) & (3) & (4) & (5) & (6) \\
\hline Gang territory & $\begin{array}{c}-0.041^{* * *} \\
(0.015)\end{array}$ & $\begin{array}{l}0.025^{* *} \\
(0.010)\end{array}$ & $\begin{array}{c}-0.060^{* * *} \\
(0.020)\end{array}$ & $\begin{array}{c}-0.076^{* * *} \\
(0.020)\end{array}$ & $\begin{array}{c}0.004^{* * *} \\
(0.001)\end{array}$ & $\begin{array}{c}-0.123^{* * *} \\
(0.027)\end{array}$ \\
\hline Mean of dep. var. & 0.942 & 0.027 & 0.939 & 0.122 & 0.003 & 0.206 \\
\hline \multirow[t]{4}{*}{ Observations } & 60,187 & 50,742 & 51,933 & 51,933 & 51,933 & 49,948 \\
\hline & \multicolumn{6}{|c|}{ Household characteristics } \\
\hline & Has a motorcycle & Has a car & Has a phone & Has a TV & Has a computer & Number of rooms \\
\hline & (7) & (8) & (9) & $(10)$ & (11) & (12) \\
\hline Gang territory & $\begin{array}{c}-0.012^{* *} \\
(0.006)\end{array}$ & $\begin{array}{c}-0.191^{* * *} \\
(0.044)\end{array}$ & $\begin{array}{c}-0.122^{* * *} \\
(0.031)\end{array}$ & $\begin{array}{c}-0.021^{* * *} \\
(0.006)\end{array}$ & $\begin{array}{c}-0.161^{* * *} \\
(0.032)\end{array}$ & $\begin{array}{c}-0.612^{* * *} \\
(0.192)\end{array}$ \\
\hline Mean of dep. var. & 0.035 & 0.475 & 0.734 & 0.958 & 0.383 & 3.249 \\
\hline \multirow[t]{4}{*}{ Observations } & 49,271 & 50,178 & 50,306 & 50,480 & 50,144 & 51,933 \\
\hline & \multicolumn{3}{|c|}{ Individual characteristics } & \multicolumn{3}{|c|}{ 1st principal component of the: } \\
\hline & $\begin{array}{l}\text { Can read } \\
\text { and write }\end{array}$ & $\begin{array}{c}\text { Has a high } \\
\text { school degree }\end{array}$ & $\begin{array}{c}\text { Has a university } \\
\text { degree }\end{array}$ & $\begin{array}{c}\text { Dwelling } \\
\text { characteristics }\end{array}$ & $\begin{array}{c}\text { Household } \\
\text { characteristics }\end{array}$ & $\begin{array}{c}\text { Individual } \\
\text { characteristics }\end{array}$ \\
\hline & (13) & (14) & (15) & $(16)$ & $(17)$ & $(18)$ \\
\hline Gang territory & $\begin{array}{c}-0.030^{* * *} \\
(0.007)\end{array}$ & $\begin{array}{c}-0.151^{* * *} \\
(0.028)\end{array}$ & $\begin{array}{c}-0.117^{* * *} \\
(0.024)\end{array}$ & $\begin{array}{c}-0.034^{* * *} \\
(0.011)\end{array}$ & $\begin{array}{c}-0.083^{* * *} \\
(0.018)\end{array}$ & $\begin{array}{c}-0.098^{* * *} \\
(0.019)\end{array}$ \\
\hline Mean of dep. var. & 0.932 & 0.475 & 0.231 & 0.957 & 0.397 & 0.540 \\
\hline Observations & 174,465 & 169,910 & 169,910 & 50,742 & 48,619 & 169,910 \\
\hline
\end{tabular}

Note: ${ }^{* *} \mathrm{p}<0.01,{ }^{* *} \mathrm{p}<0.05,{ }^{*} \mathrm{p}<0.1$. The table presents the results of estimating Specification (1) after excluding gang-controlled neighborhoods that are located within 150 meters of the rival gang. The unit of observation is a dwelling, household, or individual, depending on which characteristics are being considered. All the variable come from the 2007 census. In the individual-level regressions, the sample consists of the entire population. Omitted controls include a linear trend in distance to the boundary of gang territory, separately for locations on each side of the boundary. Standard errors in parentheses are clustered by 30 meter bins, denoting the distance to the boundary of gang territory (separately for each side of the boundary). 
Table A14: "Islands" of gang territory

\begin{tabular}{|c|c|c|c|c|c|c|}
\hline & \multicolumn{2}{|c|}{ Dwelling characteristics } & \multicolumn{4}{|c|}{ Household characteristics } \\
\hline & $\begin{array}{l}\text { Walls made } \\
\text { of concrete }\end{array}$ & Bare floor & $\begin{array}{l}\text { Has sewerage } \\
\text { infrastructure }\end{array}$ & $\begin{array}{c}\text { Use electricity for } \\
\text { lighting and cooking }\end{array}$ & No bathroom & Has internet \\
\hline & (1) & (2) & (3) & (4) & (5) & (6) \\
\hline "Island" of gang territory & $\begin{array}{c}-0.029^{* *} \\
(0.013)\end{array}$ & $\begin{array}{l}0.023^{* *} \\
(0.009)\end{array}$ & $\begin{array}{c}-0.084^{* *} \\
(0.038)\end{array}$ & $\begin{array}{c}-0.065^{* * *} \\
(0.020)\end{array}$ & $\begin{array}{c}0.006^{* * *} \\
(0.001)\end{array}$ & $\begin{array}{c}-0.103^{* * *} \\
(0.030)\end{array}$ \\
\hline Rest of gang territory & $\begin{array}{c}-0.057^{* * *} \\
(0.020)\end{array}$ & $\begin{array}{l}0.027^{* *} \\
(0.010)\end{array}$ & $\begin{array}{c}-0.028 \\
(0.028)\end{array}$ & $\begin{array}{c}-0.087^{* * *} \\
(0.022)\end{array}$ & $\begin{array}{l}0.006^{*} \\
(0.003)\end{array}$ & $\begin{array}{c}-0.148^{* * *} \\
(0.030)\end{array}$ \\
\hline Mean of dep. var. & 0.932 & 0.028 & 0.941 & 0.108 & 0.005 & 0.181 \\
\hline \multirow[t]{4}{*}{ Observations } & 72,087 & 60,675 & 62,169 & 62,169 & 62,169 & 59,776 \\
\hline & \multicolumn{6}{|c|}{ Household characteristics } \\
\hline & Has a motorcycle & Has a car & Has a phone & Has a TV & Has a computer & Number of rooms \\
\hline & $(7)$ & $(8)$ & (9) & $(10)$ & $(11)$ & $(12)$ \\
\hline "Island" of gang territory & $\begin{array}{l}-0.011^{*} \\
(0.006)\end{array}$ & $\begin{array}{c}-0.216^{* * *} \\
(0.050)\end{array}$ & $\begin{array}{c}-0.130^{* * *} \\
(0.029)\end{array}$ & $\begin{array}{c}-0.018^{* * *} \\
(0.005)\end{array}$ & $\begin{array}{c}-0.167^{* * *} \\
(0.038)\end{array}$ & $\begin{array}{c}-0.709^{* * *} \\
(0.189)\end{array}$ \\
\hline Rest of gang territory & $\begin{array}{c}-0.014^{* *} \\
(0.006)\end{array}$ & $\begin{array}{c}-0.202^{* * *} \\
(0.048)\end{array}$ & $\begin{array}{c}-0.139^{* * *} \\
(0.037)\end{array}$ & $\begin{array}{c}-0.024^{* * *} \\
(0.007)\end{array}$ & $\begin{array}{c}-0.177^{* * *} \\
(0.037)\end{array}$ & $\begin{array}{c}-0.684^{* * *} \\
(0.203)\end{array}$ \\
\hline \multirow[t]{4}{*}{ Observations } & $\begin{array}{c}0.033 \\
59,096\end{array}$ & $\begin{array}{c}0.429 \\
60,045\end{array}$ & $\begin{array}{c}0.697 \\
60,168\end{array}$ & $\begin{array}{c}0.952 \\
60,384\end{array}$ & $\begin{array}{c}0.346 \\
60,020\end{array}$ & $\begin{array}{c}3.093 \\
62,169\end{array}$ \\
\hline & \multicolumn{3}{|c|}{ Individual characteristics } & \multicolumn{3}{|c|}{ 1st principal component of the: } \\
\hline & $\begin{array}{l}\text { Can read } \\
\text { and write }\end{array}$ & $\begin{array}{c}\text { Has a high } \\
\text { school degree }\end{array}$ & $\begin{array}{c}\text { Has a university } \\
\text { degree }\end{array}$ & $\begin{array}{c}\text { Dwelling } \\
\text { characteristics }\end{array}$ & $\begin{array}{c}\text { Household } \\
\text { characteristics }\end{array}$ & $\begin{array}{c}\text { Individual } \\
\text { characteristics }\end{array}$ \\
\hline & (13) & (14) & $(15)$ & (16) & (17) & (18) \\
\hline "Island" of gang territory & $\begin{array}{l}-0.040^{* * *} \\
(0.007)\end{array}$ & $\begin{array}{c}-0.194^{* * *} \\
(0.028)\end{array}$ & $\begin{array}{l}-0.148^{* * *} \\
(0.025)\end{array}$ & $\begin{array}{c}-0.026^{* *} \\
(0.010)\end{array}$ & $\begin{array}{c}-0.087^{* * *} \\
(0.020)\end{array}$ & $\begin{array}{c}-0.127^{* * *} \\
(0.019)\end{array}$ \\
\hline Rest of gang territory & $\begin{array}{l}-0.026^{* * *} \\
(0.007)\end{array}$ & $\begin{array}{l}-0.125^{* * *} \\
(0.033)\end{array}$ & $\begin{array}{l}-0.104^{* * *} \\
(0.028)\end{array}$ & $\begin{array}{c}-0.043^{* * *} \\
(0.014)\end{array}$ & $\begin{array}{l}-0.091 * * * \\
(0.020)\end{array}$ & $\begin{array}{l}-0.084^{* * *} \\
(0.022)\end{array}$ \\
\hline Mean of dep. var. & 0.928 & 0.449 & 0.208 & 0.952 & 0.378 & 0.522 \\
\hline Observations & 208,416 & 202,935 & 202,935 & 60,675 & 58,293 & 202,935 \\
\hline
\end{tabular}

Note: ${ }^{* * *} \mathrm{p}<0.01,{ }^{* *} \mathrm{p}<0.05,{ }^{*} \mathrm{p}<0.1$. The table presents the results of estimating Specification (1) with the dummy for gang territory replaced with dummies for the "islands" of gang territory and for the other gang-controlled locations. All the variables come from the 2007 census. The unit of observation is a dwelling, household, or individual, depending on which characteristics are being considered. In the individual-level regressions, the sample consists of the entire population. Omitted controls include a linear trend in distance to the boundary of gang territory, separately for locations on each side of the boundary. Standard errors in parentheses are clustered by 30 meter bins, denoting the distance to the boundary of gang territory (separately for each side of the boundary). 
Table A15: Effect on the individual characteristics, by gender

\begin{tabular}{|c|c|c|c|c|c|c|c|c|}
\hline \multirow{3}{*}{ Subsample: } & \multicolumn{2}{|c|}{ Can read and write } & \multicolumn{2}{|c|}{ Has a high school degree } & \multicolumn{2}{|c|}{ Has a university degree } & \multicolumn{2}{|c|}{ 1st principal component } \\
\hline & Female & Male & Female & Male & Female & Male & Female & Male \\
\hline & (1) & (2) & (3) & (4) & (5) & (6) & (7) & (8) \\
\hline Gang territory & $\begin{array}{c}-0.039^{* * * *} \\
(0.009)\end{array}$ & $\begin{array}{c}-0.024^{* * *} \\
(0.005)\end{array}$ & $\begin{array}{c}-0.135^{* * *} \\
(0.025)\end{array}$ & $\begin{array}{c}-0.176^{* * *} \\
(0.033)\end{array}$ & $\begin{array}{c}-0.100^{* * *} \\
(0.021)\end{array}$ & $\begin{array}{c}-0.149^{* * *} \\
(0.032)\end{array}$ & $\begin{array}{c}-0.091^{* * *} \\
(0.018)\end{array}$ & $\begin{array}{c}-0.115^{* * *} \\
(0.023)\end{array}$ \\
\hline $\begin{array}{l}\text { Mean of dep. var. } \\
\text { Observations }\end{array}$ & $\begin{array}{c}0.915 \\
114,410\end{array}$ & $\begin{array}{c}0.943 \\
94,006\end{array}$ & $\begin{array}{c}0.432 \\
111,221\end{array}$ & $\begin{array}{c}0.469 \\
91.714\end{array}$ & $\begin{array}{c}0.186 \\
111,221\end{array}$ & $\begin{array}{c}0.234 \\
91,714\end{array}$ & $\begin{array}{c}0.505 \\
111,221\end{array}$ & $\begin{array}{c}0.543 \\
91.714\end{array}$ \\
\hline
\end{tabular}

Note: ${ }^{* * *} \mathrm{p}<0.01,{ }^{* *} \mathrm{p}<0.05,{ }^{*} \mathrm{p}<0.1$. The table presents the results of estimating Specification (1) for the individual characteristics from the 2007 census, separately for men and women. The unit of observation is an individual. The sample consists of the entire population. Omitted controls include a linear trend in distance to the boundary of gang territory, separately for locations on each side of the boundary. Standard errors in parentheses are clustered by 30 meter bins, denoting the distance to the boundary of gang territory (separately for each side of the boundary). 
Table A16: Restrictions on individuals' mobility, controlling for income and education

\begin{tabular}{|c|c|c|c|c|c|c|c|c|}
\hline & \multicolumn{2}{|c|}{$\begin{array}{c}\text { Has been to Santa Ana } \\
\text { department }\end{array}$} & \multicolumn{2}{|c|}{$\begin{array}{l}\text { Has been to } \\
\text { the beach }\end{array}$} & \multicolumn{2}{|c|}{$\begin{array}{l}\text { Always lived in } \\
\text { this location }\end{array}$} & \multicolumn{2}{|c|}{$\begin{array}{c}\text { Freedom of movement } \\
\text { where they live }\end{array}$} \\
\hline & (1) & (2) & (3) & (4) & (5) & (6) & (7) & (8) \\
\hline Gang territory & $\begin{array}{c}-0.258^{* * *} \\
(0.039)\end{array}$ & $\begin{array}{l}-0.191^{* * *} \\
(0.042)\end{array}$ & $\begin{array}{c}-0.066^{* *} \\
(0.032)\end{array}$ & $\begin{array}{l}-0.026 \\
(0.039)\end{array}$ & $\begin{array}{c}0.155^{* * *} \\
(0.043)\end{array}$ & $\begin{array}{l}0.116^{* *} \\
(0.050)\end{array}$ & $\begin{array}{l}-0.088^{* *} \\
(0.040)\end{array}$ & $\begin{array}{l}-0.092^{* *} \\
(0.043)\end{array}$ \\
\hline \multicolumn{9}{|l|}{ Gang territory $\times$} \\
\hline$\times$ Income (in thousands) & $\begin{array}{c}0.196^{* * *} \\
(0.025)\end{array}$ & $\begin{array}{c}0.158^{* * *} \\
(0.023)\end{array}$ & $\begin{array}{c}0.066^{* * *} \\
(0.016)\end{array}$ & $\begin{array}{c}0.049^{* * *} \\
(0.015)\end{array}$ & $\begin{array}{l}-0.025 \\
(0.023)\end{array}$ & $\begin{array}{l}-0.010 \\
(0.023)\end{array}$ & $\begin{array}{l}-0.032 \\
(0.036)\end{array}$ & $\begin{array}{l}-0.049 \\
(0.034)\end{array}$ \\
\hline$\times$ Has high school degree & & $\begin{array}{l}0.124^{* * *} \\
(0.020)\end{array}$ & & $\begin{array}{l}0.081^{* * *} \\
(0.012)\end{array}$ & & $\begin{array}{l}-0.059^{* *} \\
(0.023)\end{array}$ & & $\begin{array}{l}0.045^{* *} \\
(0.021)\end{array}$ \\
\hline$\times$ Has university degree & & $\begin{array}{l}0.118^{* *} \\
(0.054)\end{array}$ & & $\begin{array}{l}-0.001 \\
(0.033)\end{array}$ & & $\begin{array}{l}-0.043 \\
(0.059)\end{array}$ & & $\begin{array}{c}0.033 \\
(0.040)\end{array}$ \\
\hline \multicolumn{9}{|l|}{ Non-gang territory $x$} \\
\hline$\times$ Income (in thousands) & $\begin{array}{c}0.136^{* * *} \\
(0.034)\end{array}$ & $\begin{array}{c}0.088^{* * *} \\
(0.024)\end{array}$ & $\begin{array}{c}0.035^{* * *} \\
(0.011)\end{array}$ & $\begin{array}{c}0.016 \\
(0.008)\end{array}$ & $\begin{array}{l}-0.035^{*} \\
(0.021)\end{array}$ & $\begin{array}{c}0.000 \\
(0.017)\end{array}$ & $\begin{array}{c}-0.009 \\
(0.016)\end{array}$ & $\begin{array}{c}-0.017 \\
(0.016)\end{array}$ \\
\hline$\times$ Has high school degree & & $\begin{array}{c}0.142^{* * *} \\
(0.045)\end{array}$ & & $\begin{array}{c}0.086^{* * *} \\
(0.021)\end{array}$ & & $\begin{array}{c}-0.047 \\
(0.035)\end{array}$ & & $\begin{array}{c}-0.000 \\
(0.025)\end{array}$ \\
\hline$\times$ Has university degree & & $\begin{array}{c}0.132^{* * *} \\
(0.030)\end{array}$ & & $\begin{array}{c}0.031 \\
(0.019)\end{array}$ & & $\begin{array}{c}-0.156^{* * *} \\
(0.044)\end{array}$ & & $\begin{array}{c}0.044^{*} \\
(0.025)\end{array}$ \\
\hline Mean of dep. var. & 0.495 & 0.495 & 0.872 & 0.872 & 0.772 & 0.772 & 0.811 & 0.811 \\
\hline Observations & 2,314 & 2,275 & 2,314 & 2,275 & 2,314 & 2,275 & 2,314 & 2,275 \\
\hline
\end{tabular}

Note: ${ }^{* * *} \mathrm{p}<0.01,{ }^{* *} \mathrm{p}<0.05,{ }^{*} \mathrm{p}<0.1$. The table presents the results of estimating Specification (1) for the mobility questions from the 2019 survey, controlling for income and education. The other mobility-related questions from Table 4 are excluded because the individuals' work location directly affects income. Santa Ana is a neighboring department, which is approximately 60 kilometers away from San Salvador. The sea is approximately 30 kilometers away from San Salvador. The unit of observation is an individual. Omitted controls include a linear trend in distance to the boundary of gang territory, separately for locations on each side of the boundary. Standard errors in parentheses are clustered by 30 meter bins, denoting the distance to the boundary of gang territory (separately for each side of the boundary). 
Table A17: Restrictions on individuals' mobility and labor market outcomes, by gender

\begin{tabular}{lccccc}
\hline & $\begin{array}{c}\text { Works in } \\
\text { gang territory }\end{array}$ & $\begin{array}{c}\text { Freedom of movement } \\
\text { where they live }\end{array}$ & $\begin{array}{c}\text { Household } \\
\text { income }\end{array}$ & $\begin{array}{c}\text { Works in a firm with } \\
\geq 100 \text { employees }\end{array}$ & $\begin{array}{c}\text { Works in a firm with } \\
\geq 200 \text { employees }\end{array}$ \\
\cline { 2 - 6 } & $(1)$ & $(2)$ & $(3)$ & $(4)$ & $(5)$ \\
\hline Gang territory $\times$ Male & $\begin{array}{c}0.454^{* * *} \\
(0.042)\end{array}$ & $\begin{array}{c}-0.077^{*} \\
(0.043)\end{array}$ & $\begin{array}{c}-370.07^{* * *} \\
(114.52)\end{array}$ & $\begin{array}{c}-0.138^{* * *} \\
(0.034)\end{array}$ & $\begin{array}{c}-0.116^{* * *} \\
(0.037)\end{array}$ \\
Gang territory $\times$ Female & $\begin{array}{c}0.520^{* * *} \\
(0.045)\end{array}$ & $-0.107^{* *}$ & $-332.33^{* * *}$ & $-0.108^{* * *}$ & $-0.110^{* * *}$ \\
Mean of dep. var & 0.360 & $(0.041)$ & $(107.53)$ & $(0.019)$ & $(0.030)$ \\
Observations & 1,738 & 0.811 & 625 & 0.169 & 0.133 \\
\hline
\end{tabular}

Note: ${ }^{* * *} \mathrm{p}<0.01,{ }^{* *} \mathrm{p}<0.05,{ }^{*} \mathrm{p}<0.1$. The table presents the results of estimating Specification (1) for the mobility and labor market questions from the 2019 survey, by gender. The unit of observation is an individual. In Columns 1-2, omitted controls include a dummy for being female and a linear trend in distance to the boundary of gang territory, separately for locations on each side of the boundary. In Columns 3-5, omitted controls include a dummy for being female, a linear trend in distance to the boundary of gang territory, separately for locations on each side of the boundary, and a dummy for whether the individual is currently employed (in the survey, unemployed individuals were asked to describe their most recent work experience). Standard errors in parentheses are clustered by 30 meter bins, denoting the distance to the boundary of gang territory (separately for each side of the boundary). 
Table A18: Firms' location, profits, revenue, and costs

\begin{tabular}{|c|c|c|c|c|c|c|c|c|}
\hline & & & & \multicolumn{5}{|c|}{ Firms per $\mathrm{km}^{2}$ : } \\
\hline & \multicolumn{3}{|c|}{ Log of the firm's: } & 2005 census: & \multicolumn{4}{|c|}{ Google Maps: } \\
\hline & Profits & Revenue & Costs & All firms & All firms & $\begin{array}{c}\text { Cafes \& } \\
\text { restaurants }\end{array}$ & $\begin{array}{c}\text { Grocery } \\
\text { stores }\end{array}$ & Pharmacies \\
\hline & (1) & (2) & (3) & (4) & (5) & (6) & (7) & (8) \\
\hline Gang territory & $\begin{array}{c}-0.198 \\
(0.362)\end{array}$ & $\begin{array}{l}-0.027 \\
(0.332)\end{array}$ & $\begin{array}{c}0.094 \\
(0.330)\end{array}$ & $\begin{array}{c}-5.774 \\
(102.74)\end{array}$ & $\begin{array}{c}3.449 \\
(16.138)\end{array}$ & $\begin{array}{l}-1.022 \\
(1.542)\end{array}$ & $\begin{array}{c}0.646 \\
(0.702)\end{array}$ & $\begin{array}{l}-0.073 \\
(0.445)\end{array}$ \\
\hline Mean of dep. var. & 9.767 & 10.97 & 10.44 & 234.30 & 129.70 & 9.620 & 5.277 & 1.717 \\
\hline Observations & 5,631 & 6,118 & 6,083 & 156 & 86 & 86 & 86 & 86 \\
\hline
\end{tabular}

Note: ${ }^{* * *} \mathrm{p}<0.01,{ }^{* *} \mathrm{p}<0.05,{ }^{*} \mathrm{p}<0.1$. The table presents the results of estimating Specification (1) for the number of business establishments, their profits, revenue, and costs. The results in Columns 1-5 are based on the supplement to the 2005 economic census. In Columns 1-3, the unit of observation is a firm; in Columns 4-5-a sector, the analogue of the census tract in the economic census. The data on the number of business establishments in Columns 6-9 come from Google Maps. In these regressions, the unit of observation is a 10 meter bin, denoting distance to the boundary of gang territory, weighted by the size of the area of the distance bins. Omitted controls include a linear trend in distance to the boundary of gang territory, separately for locations on each side of the boundary. Standard errors in parentheses are clustered by 30 meter bins, denoting the distance to the boundary of gang territory (separately for each side of the boundary). 
Table A19: Gang control and exam scores

\begin{tabular}{|c|c|c|c|c|c|c|c|c|}
\hline \multirow{3}{*}{ Subsample: } & \multicolumn{2}{|c|}{ Math } & \multicolumn{2}{|c|}{ Natural sciences } & \multicolumn{2}{|c|}{ Social sciences } & \multicolumn{2}{|c|}{ Languages \& literature } \\
\hline & All obs. & Year $\leq 2007$ & All obs. & Year $\leq 2007$ & All obs. & Year $\leq 2007$ & All obs. & Year $\leq 2007$ \\
\hline & (1) & (2) & (3) & $(4)$ & (5) & (6) & (7) & (8) \\
\hline Gang territory & $\begin{array}{c}-0.835^{* *} \\
(0.337)\end{array}$ & $\begin{array}{c}-0.801^{* *} \\
(0.331)\end{array}$ & $\begin{array}{c}-0.652^{* *} \\
(0.248)\end{array}$ & $\begin{array}{c}-0.603^{* *} \\
(0.250)\end{array}$ & $\begin{array}{c}-0.666^{* * *} \\
(0.234)\end{array}$ & $\begin{array}{c}-0.686^{* *} \\
(0.278)\end{array}$ & $\begin{array}{c}-0.712^{* * *} \\
(0.240)\end{array}$ & $\begin{array}{c}-0.649^{* *} \\
(0.252)\end{array}$ \\
\hline Mean of dep. var. & 5.434 & 5.511 & 5.776 & 5.901 & 6.432 & 6.382 & 6.151 & 5.960 \\
\hline Observations & 1,284 & 436 & 1,284 & 436 & 1,284 & 436 & 1,284 & 436 \\
\hline
\end{tabular}

Note: ${ }^{* * *} \mathrm{p}<0.01,{ }^{* *} \mathrm{p}<0.05,{ }^{*} \mathrm{p}<0.1$. The table presents the results for estimating Specification (1) for the average exam scores in San Salvador schools. The data come from the schools' administrative records in 1999-2001 and 2005-2017. The unit of observation is a school in a year. Omitted controls include a linear trend in distance to the boundary of gang territory, separately for locations on each side of the boundary. Standard errors in parentheses are clustered by 30 meter bins, denoting the distance to the boundary of gang territory (separately for each side of the boundary). 
Table A20: Rates of out-of-sample migration for rich households and educated individuals from gang territory required to generate the discontinuities

\begin{tabular}{|c|c|c|c|c|c|c|}
\hline & \multicolumn{6}{|c|}{ Household characteristics } \\
\hline & $\begin{array}{l}\text { Has sewerage } \\
\text { infrastructure }\end{array}$ & $\begin{array}{l}\text { Use electricity for } \\
\text { lighting and cooking }\end{array}$ & No bathroom & Has a motocycle & Has a car & Has internet \\
\hline & (1) & (2) & (3) & (4) & (5) & (6) \\
\hline \multicolumn{7}{|c|}{$\beta$-out-of-sample migration rate for poor households and uneducated individuals from gang territory } \\
\hline$\beta=0 \%$ & $58.5 \%$ & $56.4 \%$ & $79.5 \%$ & $31.2 \%$ & $57.3 \%$ & $57.7 \%$ \\
\hline$\beta=10 \%$ & $62.6 \%$ & $60.7 \%$ & $81.6 \%$ & $38.1 \%$ & $61.6 \%$ & $61.9 \%$ \\
\hline \multirow[t]{4}{*}{$\beta=20 \%$} & $66.8 \%$ & $65.1 \%$ & $83.6 \%$ & $44.9 \%$ & $65.9 \%$ & $66.2 \%$ \\
\hline & \multicolumn{3}{|c|}{ Household characteristics } & \multicolumn{3}{|c|}{ Individual characteristics } \\
\hline & Has a phone & Has a TV & Has a computer & $\begin{array}{l}\text { Can read } \\
\text { and write }\end{array}$ & $\begin{array}{c}\text { Has a high } \\
\text { school degree }\end{array}$ & $\begin{array}{c}\text { Has a university } \\
\text { degree }\end{array}$ \\
\hline & $(7)$ & $(8)$ & (9) & $(10)$ & $(11)$ & $(12)$ \\
\hline \multicolumn{7}{|c|}{$\beta$-out-of-sample migration rate for poor households and uneducated individuals from gang territory } \\
\hline$\beta=0 \%$ & $49.7 \%$ & $38.9 \%$ & $52.7 \%$ & $40.6 \%$ & $46.2 \%$ & $51.5 \%$ \\
\hline$\beta=10 \%$ & $54.7 \%$ & $45.0 \%$ & $57.5 \%$ & $46.6 \%$ & $51.6 \%$ & $56.4 \%$ \\
\hline$\beta=20 \%$ & $59.8 \%$ & $51.1 \%$ & $62.2 \%$ & $52.5 \%$ & $57.0 \%$ & $61.2 \%$ \\
\hline
\end{tabular}

Note: The table presents the rates of out-of-sample migration for rich households and educated individuals from gang territory required to generate the discontinuities from Table 1 under different assumptions about the migration rate for poor households and uneducated individuals from gang territory. All the variables come from the 2007 census. The unit of observation is a household or an individual, depending on which characteristics are being considered. 
Table A21: Estimating the actual rates of out-of-sample migration

Family member moved abroad in 1997-2007

\begin{tabular}{|c|c|c|c|}
\hline & & & \\
\hline & $(1)$ & $(2)$ & (3) \\
\hline Gang territory & $\begin{array}{l}-0.002 \\
(0.005)\end{array}$ & $\begin{array}{c}0.000 \\
(0.004)\end{array}$ & $\begin{array}{l}-0.008 \\
(0.007)\end{array}$ \\
\hline 1st principal component of the household characteristics & $\begin{array}{c}0.063^{* * *} \\
(0.008)\end{array}$ & $\begin{array}{c}0.061^{* * *} \\
(0.008)\end{array}$ & \\
\hline \multicolumn{4}{|l|}{ 1st principal component of the household characteristics $\times$} \\
\hline$\times$ Non-gang territory & & & $\begin{array}{c}0.056^{* * *} \\
(0.011)\end{array}$ \\
\hline$\times$ Gang territory & & & $\begin{array}{c}0.071^{* * *} \\
(0.012)\end{array}$ \\
\hline Mean dep. var & 0.056 & 0.062 & 0.056 \\
\hline Observations & 36,147 & 58,293 & 36,147 \\
\hline $\begin{array}{l}p \text {-value for equal coefficients inside and } \\
\text { outside of gang territory }\end{array}$ & & & 0.313 \\
\hline Household head has always lived in San Salvador & $\checkmark$ & & $\checkmark$ \\
\hline
\end{tabular}

Note: The table presents the results of estimating the rates of out-of-sample migration from San Salvador. All the variables come from the 2007 census. The unit of observation is a household. Omitted controls include a linear trend in distance to the boundary of gang territory, separately for locations on each side of the boundary. Standard errors in parentheses are clustered by 30 meter bins, denoting the distance to the boundary of gang territory (separately for each side of the boundary). 
Table A22: McCrary density test

\begin{tabular}{|c|c|c|c|c|c|c|c|}
\hline \multirow{3}{*}{ Subsample } & \multirow{2}{*}{$\begin{array}{c}\text { Household density, per } \mathrm{km}^{2} \\
\text { All obs. }\end{array}$} & \multicolumn{6}{|c|}{ Population density, per $\mathrm{km}^{2}$ : } \\
\hline & & All obs. & Male & Female & Age 16-25 & Age 26-40 & Age $>40$ \\
\hline & (1) & (2) & (3) & (4) & (5) & (6) & (7) \\
\hline Gang territory & $\begin{array}{c}245.00 \\
(388.53)\end{array}$ & $\begin{array}{c}1,251.08 \\
(1,444.87)\end{array}$ & $\begin{array}{c}635.43 \\
(652.53)\end{array}$ & $\begin{array}{c}615.65 \\
(792.62)\end{array}$ & $\begin{array}{c}257.97 \\
(254.00)\end{array}$ & $\begin{array}{c}300.60 \\
(359.23)\end{array}$ & $\begin{array}{c}124.50 \\
(397.06)\end{array}$ \\
\hline Mean of dep. var. & 3,658 & 13,154 & 6,037 & 7,117 & 2,348 & 3,092 & 3,947 \\
\hline Observations & 476 & 476 & 476 & 476 & 476 & 476 & 476 \\
\hline
\end{tabular}

Note: ${ }^{* * *} \mathrm{p}<0.01,{ }^{* *} \mathrm{p}<0.05,{ }^{*} \mathrm{p}<0.1$. The table presents the results of estimating Specification (1) for household and population density, measured in households and individuals per square kilometer, respectively. The unit of observation is a census tract. The household count, population count, and the size of the census tracts come from the 2007 census. Omitted controls include a linear trend in distance to the boundary of gang territory, separately for locations on each side of the boundary. Observations are weighted by the size of the census tracts areas. Standard errors in parentheses are clustered by 30 meter bins, denoting the distance to the boundary of gang territory (separately for each side of the boundary). 
Table A23: Informal public goods provision

\begin{tabular}{|c|c|c|c|c|c|c|}
\hline & \multicolumn{3}{|c|}{$\begin{array}{l}\text { Would seek help from informal leader } \\
\text { of the community if a problem with: }\end{array}$} & \multicolumn{3}{|c|}{$\begin{array}{l}\text { Would not seek help from anyone } \\
\text { if a problem with: }\end{array}$} \\
\hline & $\begin{array}{l}\text { Public goods } \\
\text { provision }\end{array}$ & $\begin{array}{l}\text { Security, civil, } \\
\text { or legal dispute }\end{array}$ & Finance & $\begin{array}{l}\text { Public goods } \\
\text { provision }\end{array}$ & $\begin{array}{l}\text { Security, civil, } \\
\text { or legal dispute }\end{array}$ & Finance \\
\hline & (1) & (2) & (3) & (4) & (5) & (6) \\
\hline Gang territory & $\begin{array}{c}0.055 \\
(0.059)\end{array}$ & $\begin{array}{l}-0.059 \\
(0.044)\end{array}$ & $\begin{array}{l}-0.012 \\
(0.010)\end{array}$ & $\begin{array}{l}0.052^{* *} \\
(0.022)\end{array}$ & $\begin{array}{l}0.045^{* * *} \\
(0.012)\end{array}$ & $\begin{array}{l}0.059^{*} \\
(0.029)\end{array}$ \\
\hline Mean of dep. var. & 0.220 & 0.090 & 0.013 & 0.084 & 0.046 & 0.115 \\
\hline Observations & 2,314 & 2,314 & 2,314 & 2,314 & 2,314 & 2,314 \\
\hline
\end{tabular}

Note: ${ }^{* *} \mathrm{p}<0.01,{ }^{* *} \mathrm{p}<0.05,{ }^{*} \mathrm{p}<0.1$. The table presents the results of estimating Specification (1) for the probability of seeking help from an informal community leader or not seeking help from anyone to solve problems with public goods provision, finance, and security, civil, and legal disputes. The term "informal community leader" is used as a proxy for "gang leader" because, for security reasons, the survey could not directly mention the gangs. When conducting the pilot of the survey, we have verified that all the pilot respondents associated the term "informal leader of the community" with the gangs. The unit of observation is an individual. Omitted controls include a linear trend in distance to the boundary of gang territory, separately for locations on each side of the boundary. Standard errors in parentheses are clustered by 30 meter bins, denoting the distance to the boundary of gang territory (separately for each side of the boundary). 
Table A24: Socioeconomic conditions after exposure to gang control, subsample of employed individuals

\begin{tabular}{|c|c|c|c|c|c|}
\hline & \multicolumn{5}{|c|}{ Household characteristics } \\
\hline & $\begin{array}{l}\text { Has sewerage } \\
\text { infrastructure }\end{array}$ & $\begin{array}{l}\text { Use electricity for } \\
\text { lighting and cooking }\end{array}$ & No bathroom & Has internet & Has motocycle \\
\hline & (1) & $(2)$ & (3) & (4) & (5) \\
\hline Gang territory & $\begin{array}{c}-0.047^{* *} \\
(0.022)\end{array}$ & $\begin{array}{c}-0.075^{* * *} \\
(0.020)\end{array}$ & $\begin{array}{l}0.005^{* *} \\
(0.002)\end{array}$ & $\begin{array}{c}-0.152^{* * *} \\
(0.032)\end{array}$ & $\begin{array}{c}-0.017^{* *} \\
(0.007)\end{array}$ \\
\hline Mean of dep. var. & 0.940 & 0.105 & 0.004 & 0.207 & 0.039 \\
\hline \multirow[t]{4}{*}{ Observations } & 41,073 & 41,073 & 41,073 & 39,733 & 39,285 \\
\hline & \multicolumn{5}{|c|}{ Household characteristics } \\
\hline & Has a car & Has a phone & Has a TV & Has a computer & Number of rooms \\
\hline & (6) & $(7)$ & (8) & (9) & $(10)$ \\
\hline Gang territory & $\begin{array}{l}-0.224^{* * *} \\
(0.047)\end{array}$ & $\begin{array}{l}-0.134^{* * *} \\
(0.032)\end{array}$ & $\begin{array}{l}-0.018^{* * *} \\
(0.005)\end{array}$ & $\begin{array}{l}-0.185^{* * *} \\
(0.040)\end{array}$ & $\begin{array}{l}-0.685^{* * *} \\
(0.200)\end{array}$ \\
\hline \multirow[t]{4}{*}{ Observations } & $\begin{array}{c}0.466 \\
39,907\end{array}$ & $\begin{array}{c}0.683 \\
39,961\end{array}$ & $\begin{array}{c}0.959 \\
40,115\end{array}$ & $\begin{array}{c}0.389 \\
39,902\end{array}$ & $\begin{array}{c}3.069 \\
41,073\end{array}$ \\
\hline & \multicolumn{3}{|c|}{ Individual characteristics } & \multicolumn{2}{|c|}{ 1st principal component of the: } \\
\hline & $\begin{array}{l}\text { Can read } \\
\text { and write }\end{array}$ & $\begin{array}{c}\text { Has a high } \\
\text { school degree }\end{array}$ & $\begin{array}{c}\text { Has a university } \\
\text { degree }\end{array}$ & $\begin{array}{c}\text { Household } \\
\text { characteristics }\end{array}$ & $\begin{array}{c}\text { Individual } \\
\text { characteristics }\end{array}$ \\
\hline & $(11)$ & $(12)$ & (13) & (14) & (15) \\
\hline Gang territory & $\begin{array}{c}-0.019^{* * *} \\
(0.004)\end{array}$ & $\begin{array}{l}-0.180^{* * *} \\
(0.033)\end{array}$ & $\begin{array}{l}-0.184^{* * *} \\
(0.033)\end{array}$ & $\begin{array}{l}-0.095^{* * *} \\
(0.020)\end{array}$ & $\begin{array}{l}-0.128^{* * *} \\
(0.022)\end{array}$ \\
\hline Mean of dep. var. & 0.967 & 0.624 & 0.333 & 0.388 & 0.635 \\
\hline Observations & 90,944 & 88,653 & 88,653 & 38,747 & 88,653 \\
\hline
\end{tabular}

Note: ${ }^{* * *} p<0.01,{ }^{* *} p<0.05,{ }^{*} p<0.1$. The table presents the results of estimating Specification (1) for the variables from the 2007 census for the subsample of employed individuals. For the household characteristics, we limit the sample to those observations for which the head of the household is employed. The unit of observation is a household or an individual, depending on which characteristics are being considered. In the individual-level regressions, the sample consists of the entire population of employed individuals. Omitted controls include a linear trend in distance to the boundary of gang territory, separately for locations on each side of the boundary. Standard errors in parentheses are clustered by 30 meter bins, denoting the distance to the boundary of gang territory (separately for each side of the boundary). 
Table A25: Socioeconomic conditions after exposure to gang control, subsample of formally employed individuals

\begin{tabular}{|c|c|c|c|c|c|}
\hline & \multicolumn{5}{|c|}{ Household characteristics } \\
\hline & $\begin{array}{l}\text { Has sewerage } \\
\text { infrastructure }\end{array}$ & $\begin{array}{l}\text { Use electricity for } \\
\text { lighting and cooking }\end{array}$ & No bathroom & Has internet & Has motocycle \\
\hline & (1) & (2) & (3) & (4) & (5) \\
\hline Gang territory & $\begin{array}{c}-0.045^{* *} \\
(0.020)\end{array}$ & $\begin{array}{c}-0.074^{* * *} \\
(0.020)\end{array}$ & $\begin{array}{c}0.004^{* * *} \\
(0.001)\end{array}$ & $\begin{array}{l}-0.152^{* * *} \\
(0.035)\end{array}$ & $\begin{array}{l}-0.015^{*} \\
(0.008)\end{array}$ \\
\hline Mean of dep. var. & 0.947 & 0.122 & 0.003 & 0.247 & 0.043 \\
\hline \multirow[t]{4}{*}{ Observations } & 28,201 & 28,201 & 28,201 & 27,314 & 26,937 \\
\hline & \multicolumn{5}{|c|}{ Household characteristics } \\
\hline & Has a car & Has a phone & Has a TV & Has a computer & Number of rooms \\
\hline & (6) & (7) & (8) & (9) & (10) \\
\hline Gang territory & $\begin{array}{c}-0.219^{* * *} \\
(0.048)\end{array}$ & $\begin{array}{l}-0.124^{* * *} \\
(0.032)\end{array}$ & $\begin{array}{l}-0.011^{* *} \\
(0.005)\end{array}$ & $\begin{array}{c}-0.173^{* * *} \\
(0.041)\end{array}$ & $\begin{array}{l}-0.700^{* * *} \\
(0.210)\end{array}$ \\
\hline Mean of dep. var. & 0.521 & 0.727 & 0.969 & 0.452 & 3.230 \\
\hline \multirow[t]{4}{*}{ Observations } & 27,418 & 27,442 & 27,556 & 27,423 & 28,201 \\
\hline & \multicolumn{3}{|c|}{ Individual characteristics } & \multicolumn{2}{|c|}{ 1st principal component of the: } \\
\hline & $\begin{array}{l}\text { Can read } \\
\text { and write }\end{array}$ & $\begin{array}{c}\text { Has a high } \\
\text { school degree }\end{array}$ & $\begin{array}{c}\text { Has a university } \\
\text { degree }\end{array}$ & $\begin{array}{c}\text { Household } \\
\text { characteristics }\end{array}$ & $\begin{array}{c}\text { Individual } \\
\text { characteristics }\end{array}$ \\
\hline & $(11)$ & (12) & (13) & (14) & (15) \\
\hline Gang territory & $\begin{array}{c}-0.009^{* * *} \\
(0.002)\end{array}$ & $\begin{array}{c}-0.170^{* * *} \\
(0.032)\end{array}$ & $\begin{array}{c}-0.195^{* * *} \\
(0.036)\end{array}$ & $\begin{array}{c}-0.092^{* * *} \\
(0.021)\end{array}$ & $\begin{array}{c}-0.125^{* * *} \\
(0.022)\end{array}$ \\
\hline $\begin{array}{l}\text { Mean of dep. var. } \\
\text { Observations }\end{array}$ & $\begin{array}{c}0.987 \\
63,455\end{array}$ & $\begin{array}{c}0.740 \\
62,136\end{array}$ & $\begin{array}{c}0.416 \\
62,136\end{array}$ & $\begin{array}{c}0.415 \\
26,564\end{array}$ & $\begin{array}{c}0.707 \\
62,136\end{array}$ \\
\hline
\end{tabular}

Note: ${ }^{* *} \mathrm{p}<0.01,{ }^{* *} \mathrm{p}<0.05,{ }^{*} \mathrm{p}<0.1$. The table presents the results of estimating Specification (1) for the variables from the 2007 census for the subsample of formally employed individuals. For the household characteristics, we limit the sample to those observations for which the head of the household is employed. The unit of observation is a household or an individual, depending on which characteristics are being considered. In the individual-level regressions, the sample consists of the entire population of formally employed individuals. Omitted controls include a linear trend in distance to the boundary of gang territory, separately for locations on each side of the boundary. Standard errors in parentheses are clustered by 30 meter bins, denoting the distance to the boundary of gang territory (separately for each side of the boundary). 
Table A26: Hours worked

\begin{tabular}{lcccc}
\hline & \multicolumn{3}{c}{ Hours worked } & \multicolumn{3}{c}{ Number of hours would work for a wage of: } \\
\cline { 3 - 5 } & $(1)$ & \$5 per hour & \$10 per hour & \$20 per hour \\
\cline { 2 - 5 } & 0.050 & -0.371 & $(3)$ & $(4)$ \\
\hline Gang territory & $(0.421)$ & $(0.341)$ & $(0.239)$ & 0.336 \\
Mean of dep. var. & 8.613 & 7.596 & 8.280 & 8.245 \\
Observations & 2,071 & 2,314 & 2,314 & 2,314 \\
\hline
\end{tabular}

Note: ${ }^{* * *} \mathrm{p}<0.01,{ }^{* *} \mathrm{p}<0.05,{ }^{*} \mathrm{p}<0.1$. The table presents the results of estimating Specification (1) for the number of hours worked and for individuals' willingness to work. All the variables come from the 2019 survey. The unit of observation is an individual. Omitted controls include a linear trend in distance to the boundary of gang territory, separately for locations on each side of the boundary. Standard errors in parentheses are clustered by 30 meter bins, denoting the distance to the boundary of gang territory (separately for each side of the boundary). 


\section{FIGURES}

Figure A1: Socioeconomic conditions after 10 years of gang control: Dwelling characteristics
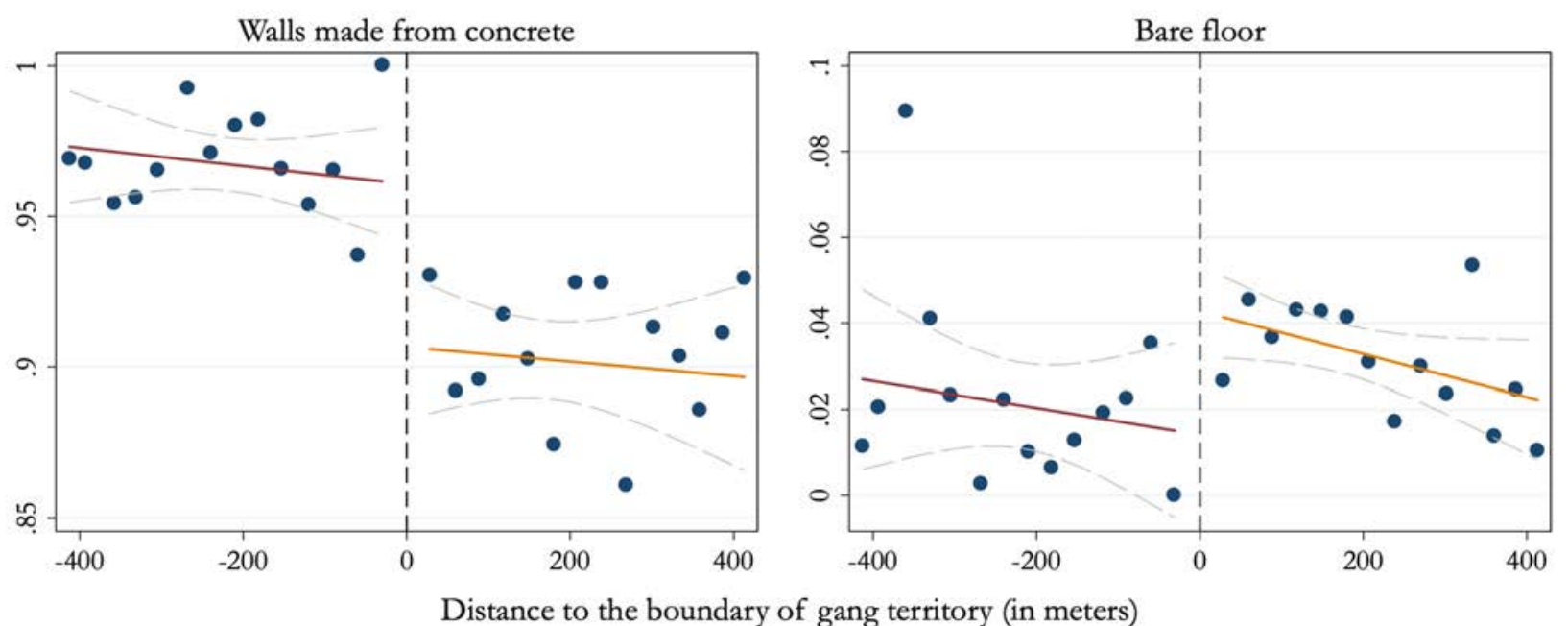

Distance to the boundary of gang territory (in meters)

Mean of the outcome variable, by 30 meter bins
Linear prediction (outside of gang territory)

Note: The figure illustrates the results for the dwelling characteristics from Table 1 . All the variables come from the 2007 census. The unit of observation is a dwelling. All the variables represent the share of dwellings that have the outcome variable (walls from concrete and a bare floor). The vertical axis represents the average value of the outcomes variable; the horizontal axis-distance (in meters) to the boundary of gang territory. Neighborhoods to the left of the dashed line are located outside of gang territory; areas to the right are controlled by the gangs. The dots represent the average value of the outcome variable in that 30 meter bin. 
Figure A2: Socioeconomic conditions after 10 years of gang control: Household characteristics
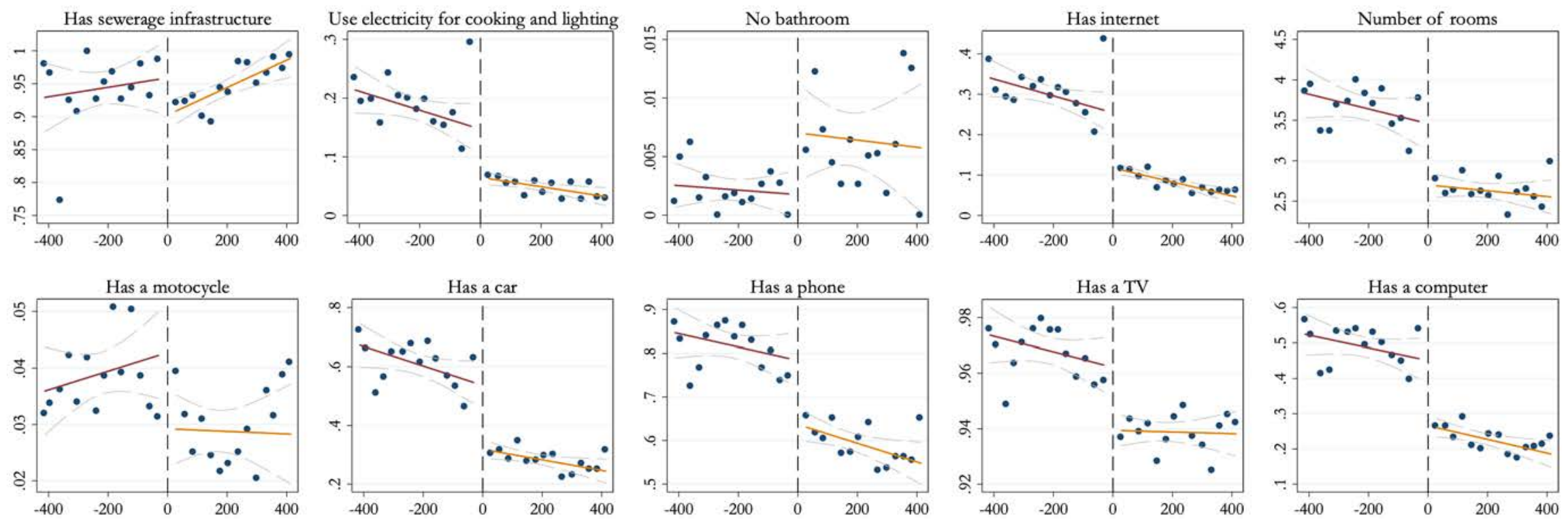

$\mathrm{X}$-axis: Distance to the boundary of gang territory (in meters)

\begin{tabular}{|ll|}
\hline $\begin{array}{l}\text { Mean of the outcome variable, by } 30 \text { meter bins } \\
\text { Linear prediction (outside of gang territory) }\end{array}-95 \%$ confidence interval \\
\hline
\end{tabular}

Note: The figure illustrates the results for the households characteristics from Table 1 . All the variables come from the 2007 census. The unit of observation is a household. All the variables except "Number of rooms" represent the share of households that have the outcome variable (a car, a tv, etc.); "Number of rooms" is the number of rooms in the apartment or house where the household lives. The vertical axis represents the average value of the outcomes variable; the horizontal axis- distance (in meters) to the boundary of gang territory. Neighborhoods to the left of the dashed line are located outside of gang territory; areas to the right are controlled by the gangs. The dots represent the average value of the outcome variable in that 30 meter bin. 
Figure A3: Socioeconomic conditions after 10 years of gang control: Individual characteristics
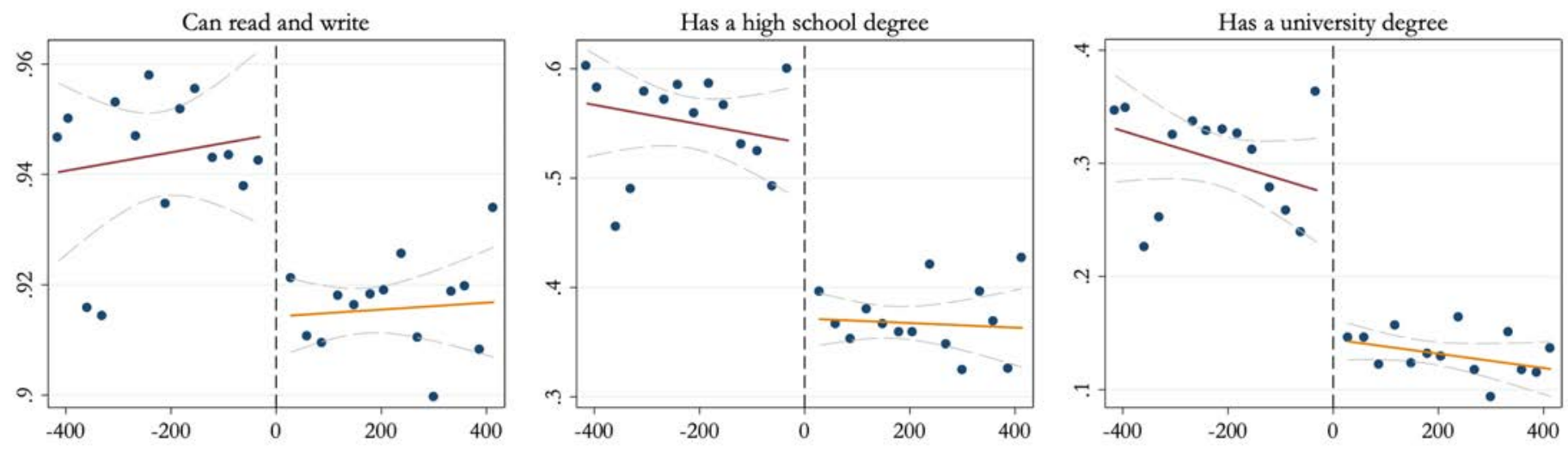

Distance to the boundary of gang territory (in meters)

- Mean of the outcome variable, by 30 meter bins

$95 \%$ confidence interval

Linear prediction (outside of gang territory) Linear prediction (gang territory)

Note: The figure illustrates the results for the individual characteristics from Table 1 . All the variables come from the 2007 census. The unit of observation is an individual. All the variables represent the share of individuals that have the outcome variable (can read and write, have a high school degree, etc.). The vertical axis represents the average value of the outcomes variable; the horizontal axis-distance (in meters) to the boundary of gang territory. Neighborhoods to the left of the dashed line are located outside of gang territory; areas to the right are controlled by the gangs. The dots represent the average value of the outcome variable in that 30 meter bin. 
Figure A4: Household income after 22 years of gang control

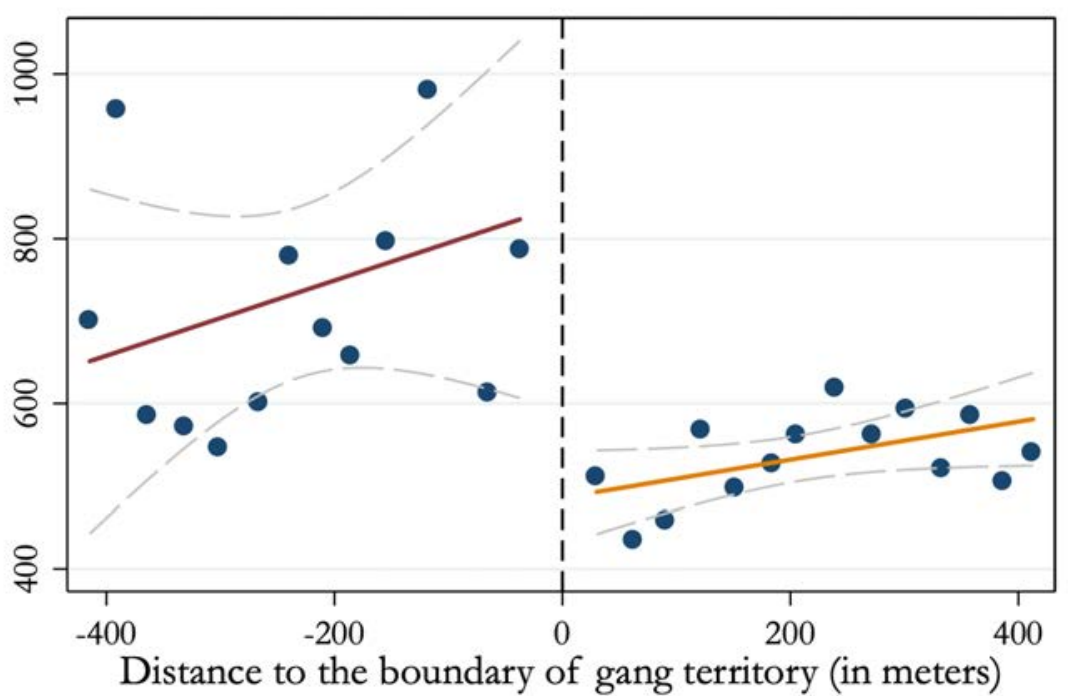

Distance to the

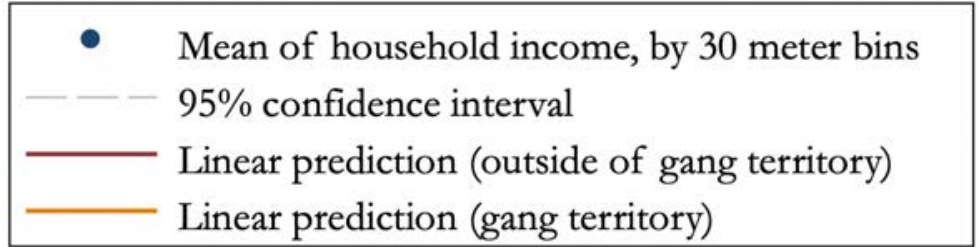

Note: Residents of gang territory earn $\$ 350$ less income per month than individuals who do not live under gang control. The outcome variable comes from the 2019 survey. The vertical axis represents the average value of the outcomes variable; the horizontal axis-distance (in meters) to the boundary of gang territory. Neighborhoods to the left of the dashed line are located outside of gang territory; areas to the right are controlled by the gangs. The dots represent the average value of the outcome variable in that 30 meter bin. 
Figure A5: Socioeconomic conditions before the gangs' arrival: Neighborhood characteristics
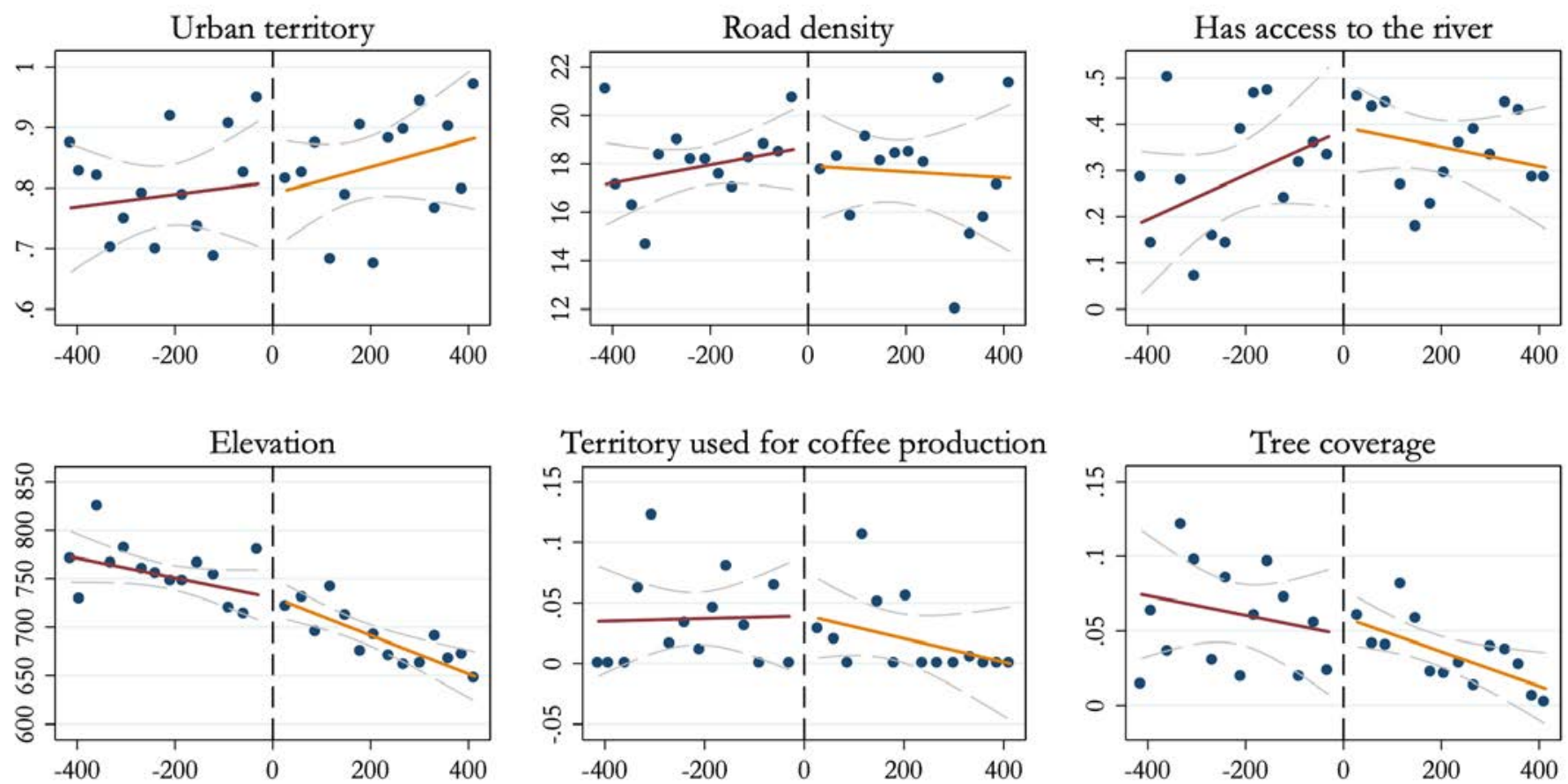

Territory used for coffee production
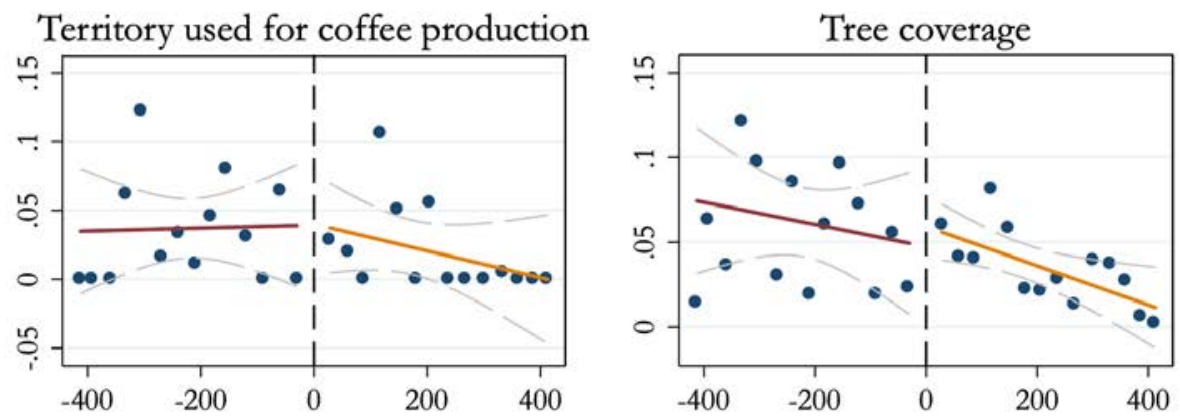

$\mathrm{X}$-axis: Distance to the boundary of gang territory (in meters)

Mean of the outcome variable, by 30 meter bins

Linear prediction (outside of gang territory)
$95 \%$ confidence interval

Linear prediction (gang territory)

Note: The figure illustrates the results for the neighborhood characteristics from Table 2. The unit of observation is a census tract. The vertical axis represents the average value of the outcomes variable; the horizontal axis-distance (in meters) to the boundary of gang territory. Neighborhoods to the left of the dashed line are located outside of gang territory; areas to the right are controlled by the gangs. The dots represent the average value of the outcome variable in that 30 meter bin. 
Figure A6: Socioeconomic conditions before the gangs' arrival: Dwelling characteristics
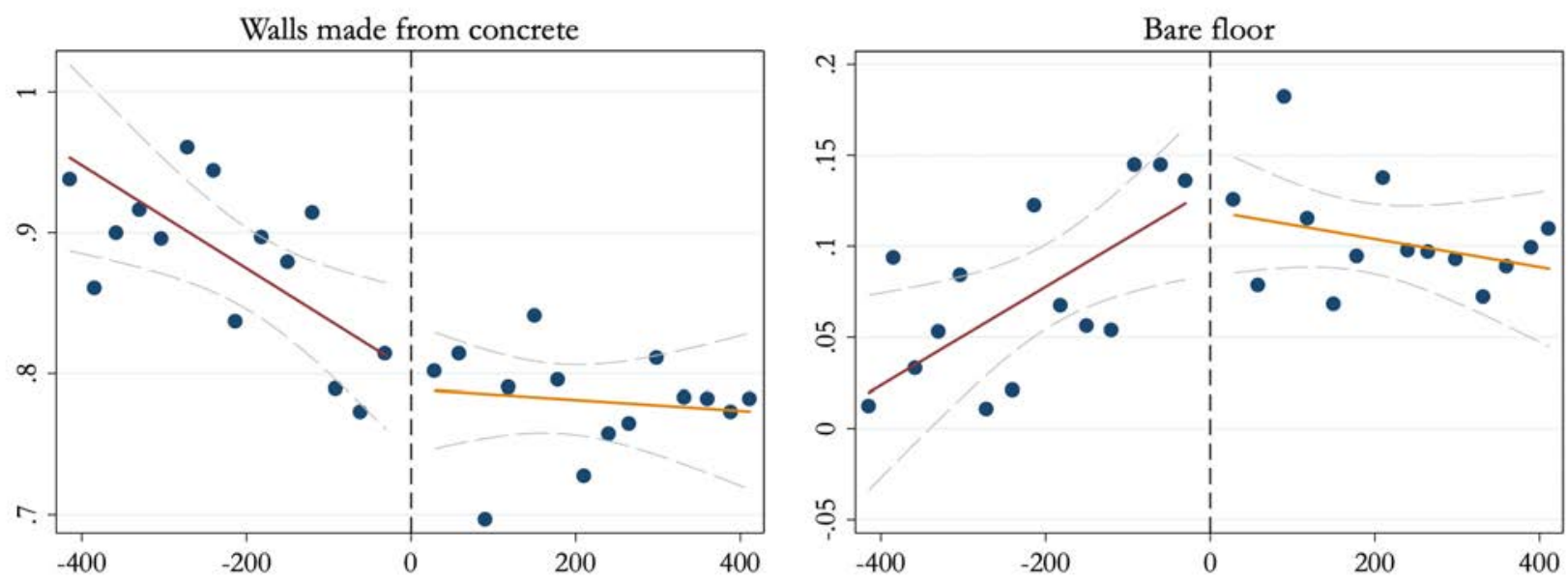

Distance to the boundary of gang territory (in meters)

- Mean of the outcome variable, by 30 meter bins

Linear prediction (outside of gang territory)
$95 \%$ confidence interval Linear prediction (gang territory)

Note: The figure illustrates the results for the dwelling characteristics from Table 2. All the variables come from the 1992 census. The unit of observation is a dwelling. All the variables represent the share of dwellings that have the outcome variable (walls from concrete and a bare floor). The vertical axis represents the average value of the outcomes variable; the horizontal axis-distance (in meters) to the boundary of gang territory. Neighborhoods to the left of the dashed line are located outside of gang territory; areas to the right are controlled by the gangs. The dots represent the average value of the outcome variable in that 30 meter bin. 
Figure A7: Socioeconomic conditions before the gangs' arrival: Household characteristics
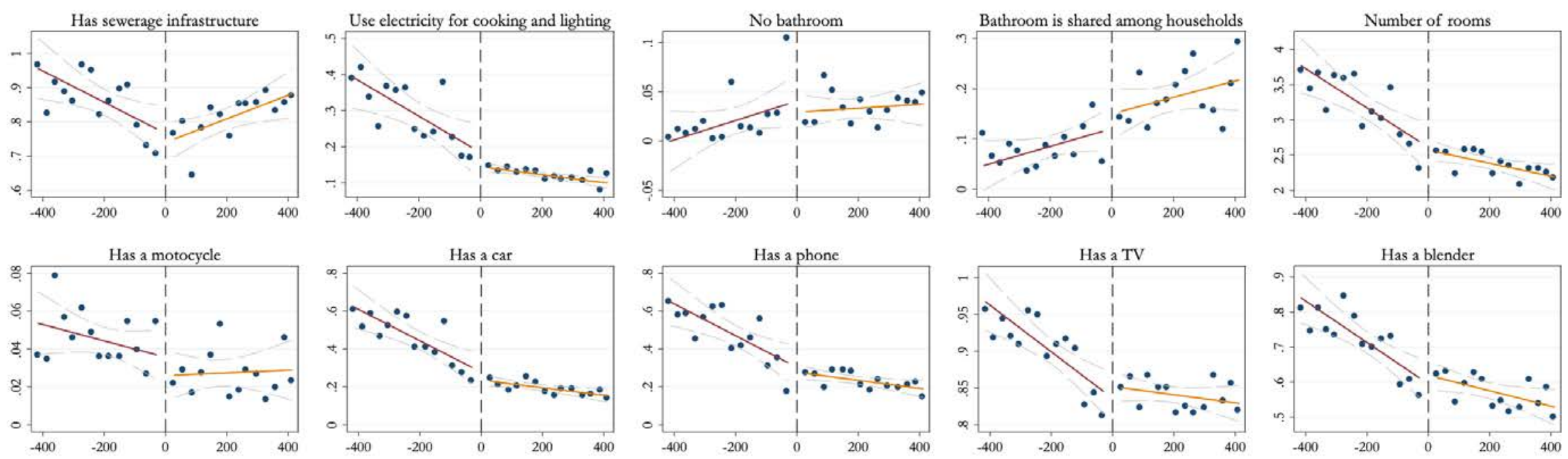

\section{$\mathrm{X}$-axis: Distance to the boundary of gang territory (in meters)}

\begin{tabular}{ll|}
\hline Mean of the outcome variable, by 30 meter bins & $--95 \%$ confidence interval \\
Linear prediction (outside of gang territory) & Linear prediction (gang territory) \\
\hline
\end{tabular}

Note: The figure illustrates the results for the households characteristics from Table 2. All the variables come from the 1992 census. The unit of observation is a household. All the variables except "Number of rooms" represent the share of households that have the outcome variable (a car, a tv, etc.); "Number of rooms" is the number of rooms in the apartment or house where the household lives. The vertical axis represents the average value of the outcomes variable; the horizontal axis-distance (in meters) to the boundary of gang territory. Neighborhoods to the left of the dashed line are located outside of gang territory; areas to the right are controlled by the gangs. The dots represent the average value of the outcome variable in that 30 meter bin. 
Figure A8: Socioeconomic conditions before the gangs' arrival: Individual characteristics
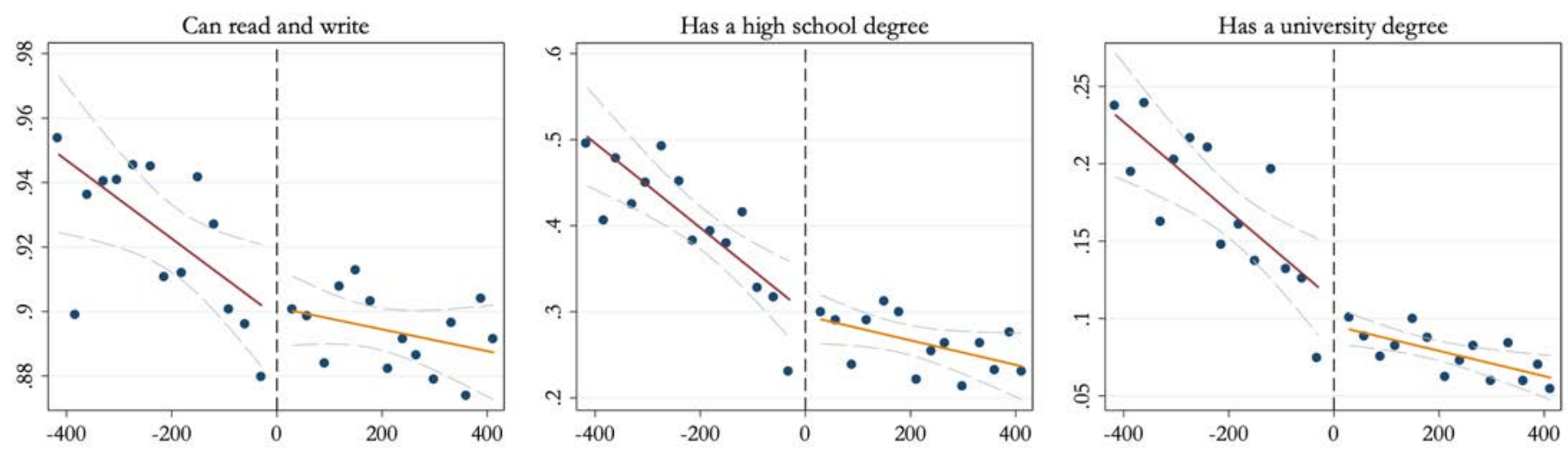

Distance to the boundary of gang territory (in meters)

- Mean of the outcome variable, by 30 meter bins

$95 \%$ confidence interval

Linear prediction (outside of gang territory)

Linear prediction (gang territory)

Note: The figure illustrates the results for the individual characteristics from Table 2. All the variables come from the 1992 census. The unit of observation is an individual. All the variables represent the share of individuals that have the outcome variable (can read and write, have a high school degree, etc.). The vertical axis represents the average value of the outcomes variable; the horizontal axis-distance (in meters) to the boundary of gang territory. Neighborhoods to the left of the dashed line are located outside of gang territory; areas to the right are controlled by the gangs. The dots represent the average value of the outcome variable in that 30 meter bin. 
Figure A9: Socioeconomic conditions before the gangs' arrival: 1st principal components of the dwelling, household, and individual characteristics

1st principal component of:
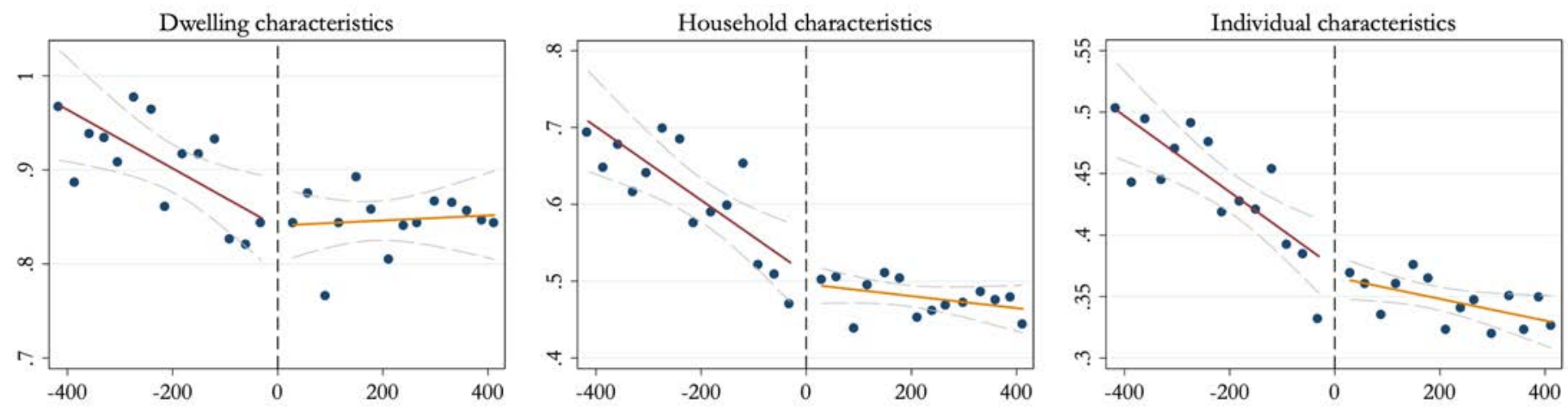

Distance to the boundary of gang territory (in meters)

$\begin{array}{ll}\text { - Mean of the outcome variable, by } 30 \text { meter bins } & -15 \% \text { confidence interval } \\ - \text { Linear prediction (outside of gang territory) } & \text { Linear prediction (gang territory) }\end{array}$

Note: The figure illustrates the results for the 1st principal components of the dwelling, household, and individual characteristics from Table 2. All the variables come from the 1992 census. The unit of observation is a dwelling, a household, and an individual, depending on the specification. All the variables are normalized to vary between zero and one with higher values representing better outcomes. The vertical axis represents the average value of the outcomes variable; the horizontal axis-distance (in meters) to the boundary of gang territory. Neighborhoods to the left of the dashed line are located outside of gang territory; areas to the right are controlled by the gangs. The dots represent the average value of the outcome variable in that 30 meter bin. 
Figure A10: In-sample migration is not driving the results
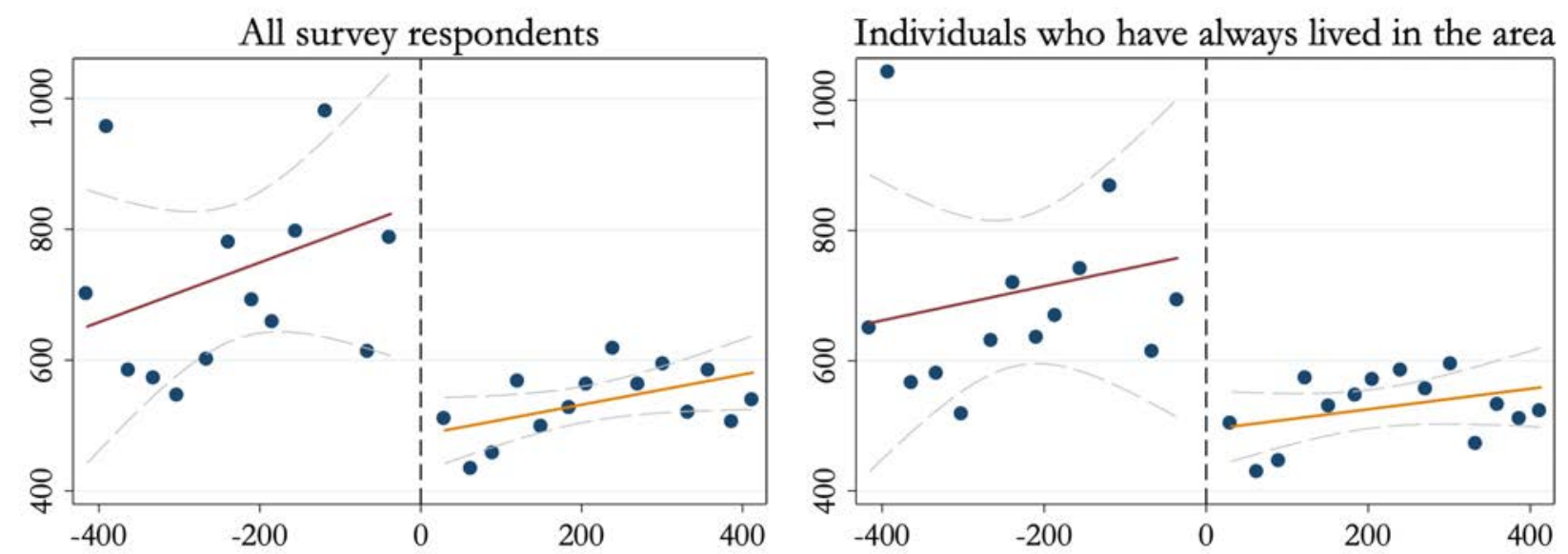

Distance to the boundary of gang territory (in meters)

\begin{tabular}{cll|}
\hline Mean of household income, by 30 meter bins & - $95 \%$ confidence interval \\
- Linear prediction (outside of gang territory) & Linear prediction (gang territory) \\
\hline
\end{tabular}

Note: The figure illustrates the results for household income from Table A5. The left-hand side of the figure presents the results for the full sample (Panel A of Table A5), the right-hand side-for the subsample of individuals who have lived in the same location all their life (Panel B of Table A5). The results are very similar. The vertical axis represents the average value of household income; the horizontal axis-distance (in meters) to the boundary of gang territory. Neighborhoods to the left of the dashed line are located outside of gang territory; areas to the right are controlled by the gangs. The dots represent the average value of the outcome variable in that 30 meter bin. 
Figure A11: Placebo natural boundaries

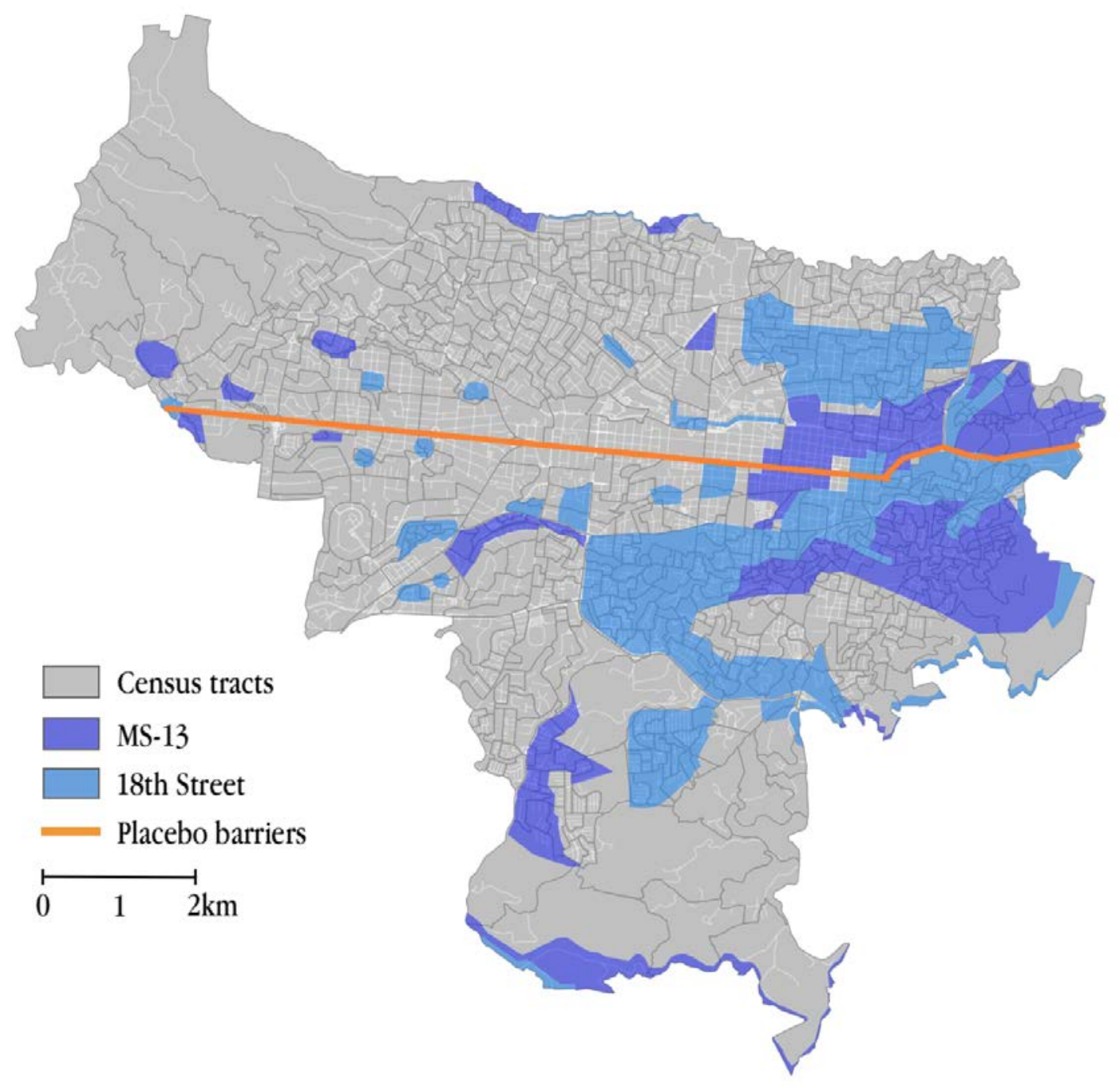


Figure A12: Gang presence and nighttime light density
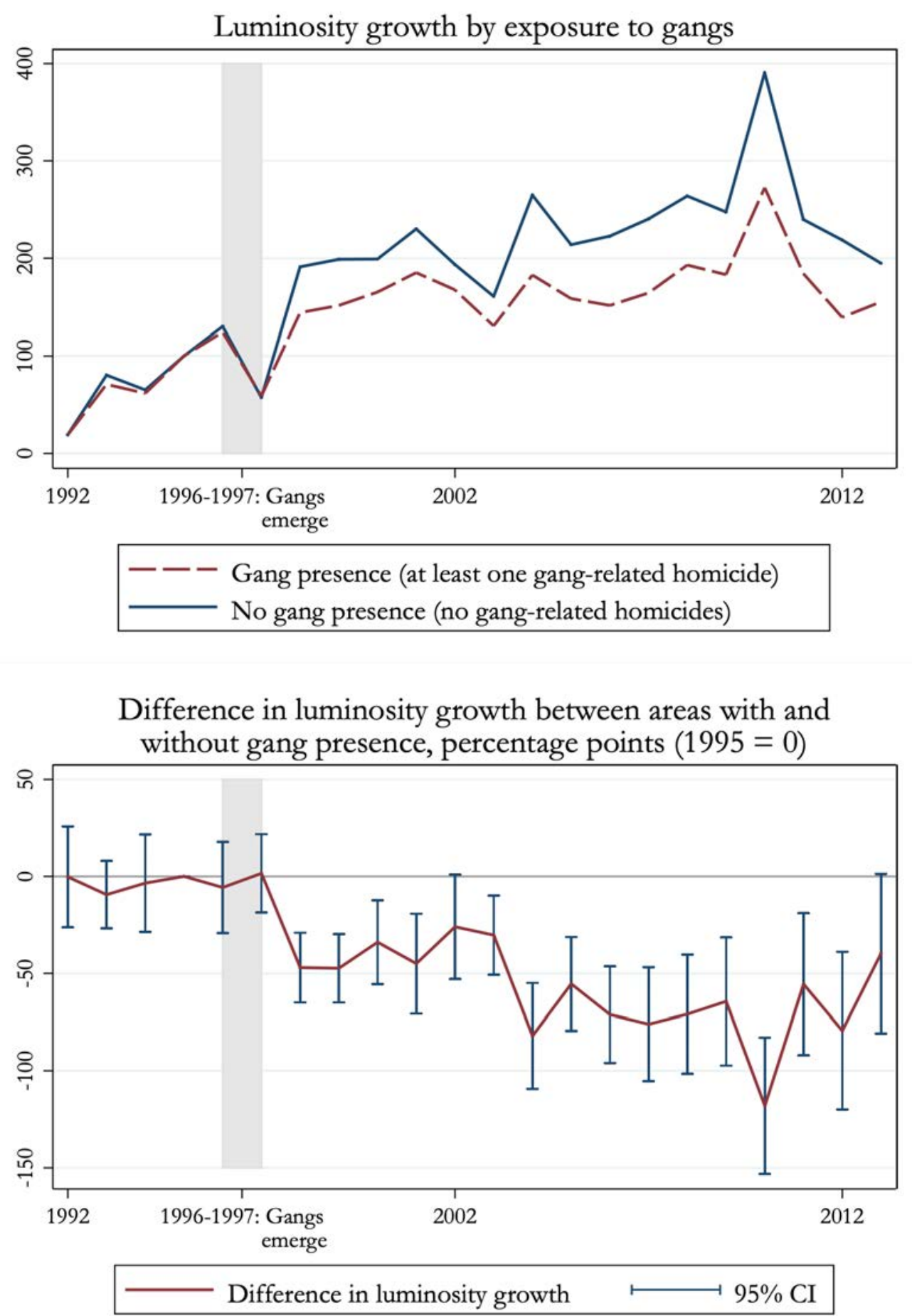

Note: The first part of the figure illustrates the growth in nighttime light density in grid cells with and without gang presence. The data are in percentage points, normalized to be equal to 100 percent in 1995, one year before the announcement of the change in the United States immigration policy. The second part of the figure presents an event study graph for the average percentage point difference in nighttime light density between grid cells with and without gang presence. 

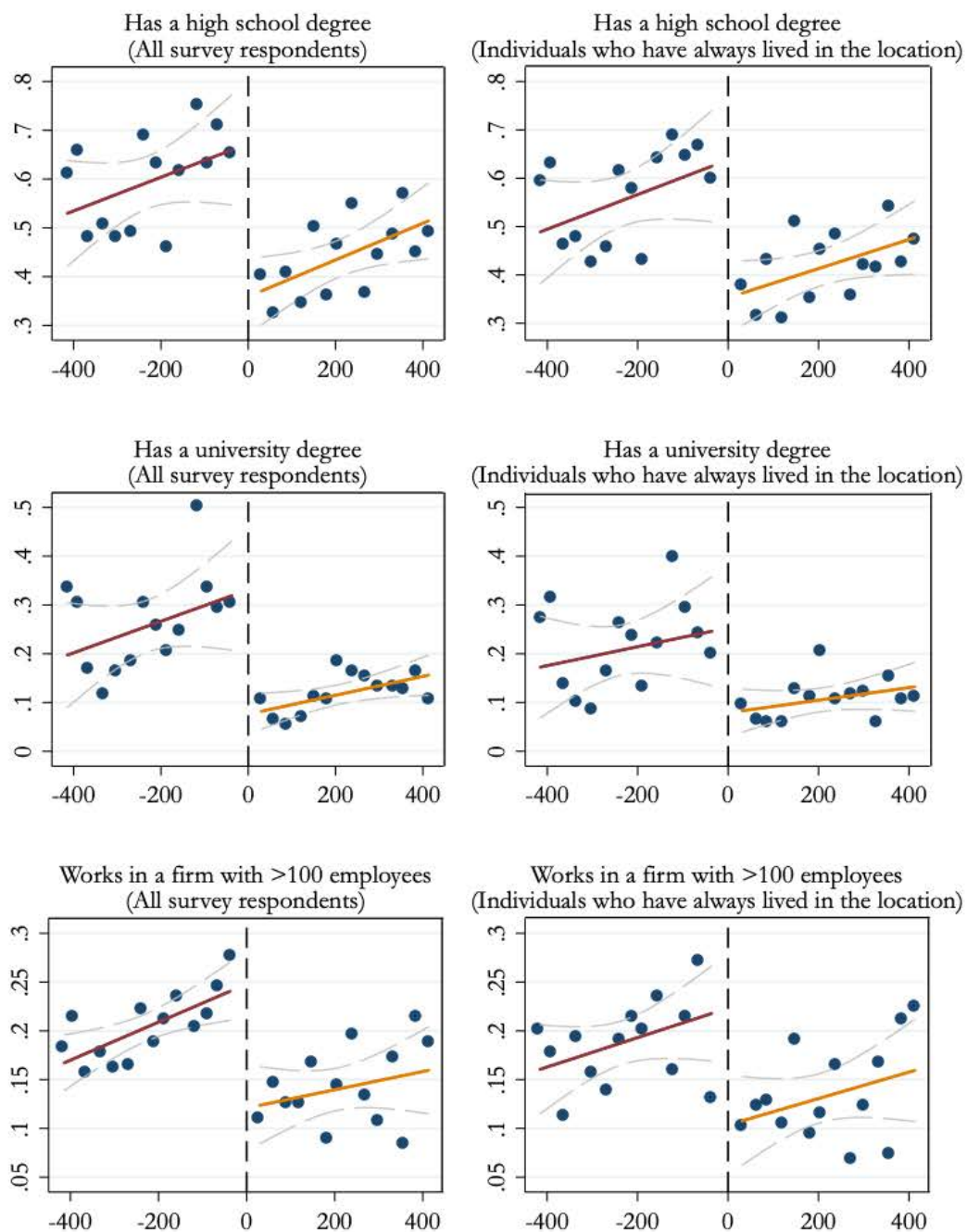

Works in a firm with $>100$ employees (Individuals who have always lived in the location)
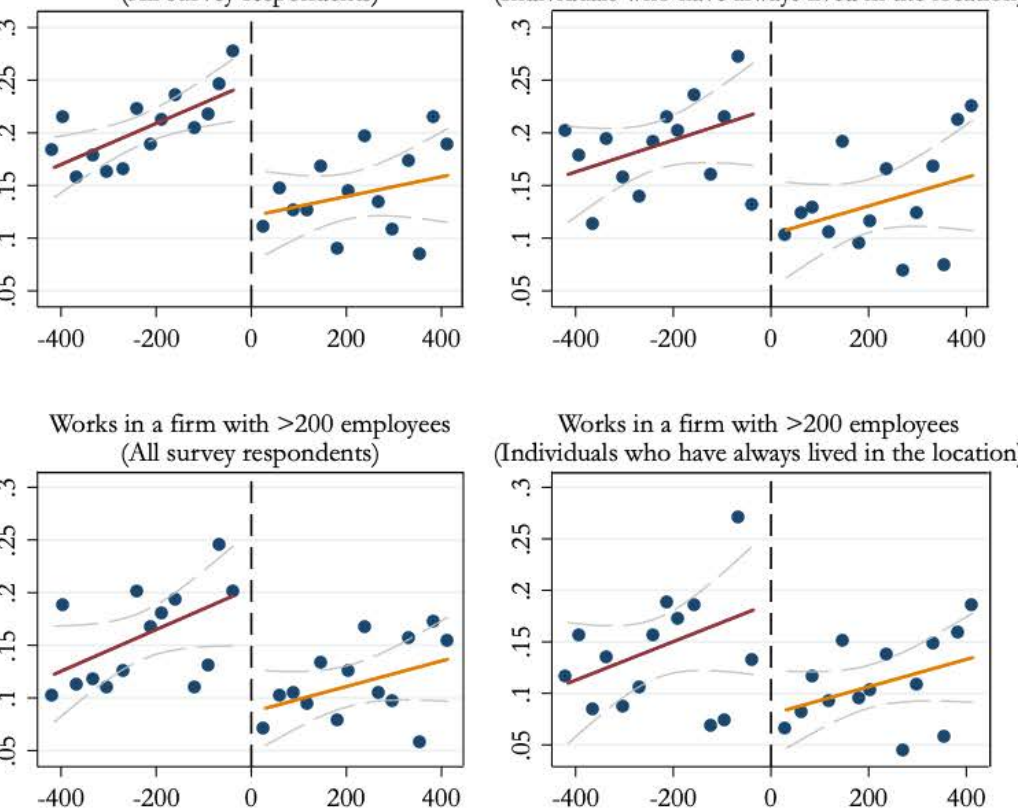

Works in a firm with $>200$ employees (Individuals who have always lived in the location)

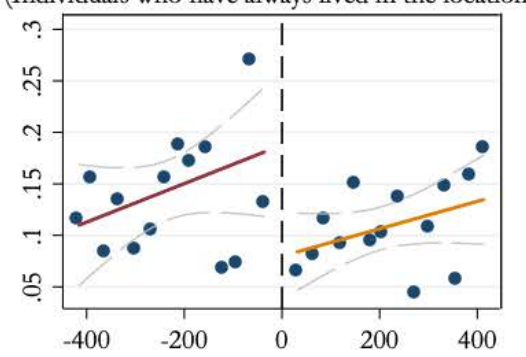

Distance to the boundary of gang territory (in meters)

Mean of the outcome variable, by 30 meter bins
$-\quad 95 \%$ confidence interval
Linear prediction (outside of gang territory)
Linear prediction (gang territory)

Note: The figure illustrates the results from Table A5. The left-hand side of the figure presents the results for the full sample (Panel A of Table A5), the right-hand side-for the subsample of individuals who have lived in the same location all their life (Panel B of Table A5). The results are very similar. The vertical axis represents the average value of household income; the horizontal axis-distance (in meters) to the boundary of gang territory. Neighborhoods to the left of the dashed line are located outside of gang territory; areas to the right are controlled by the gangs. The dots represent the average value of the outcome variable in that 30 meter bin. 
Figure A14: Excluding observations within 100 meters of the boundary of gang territory

1st principal component of the:
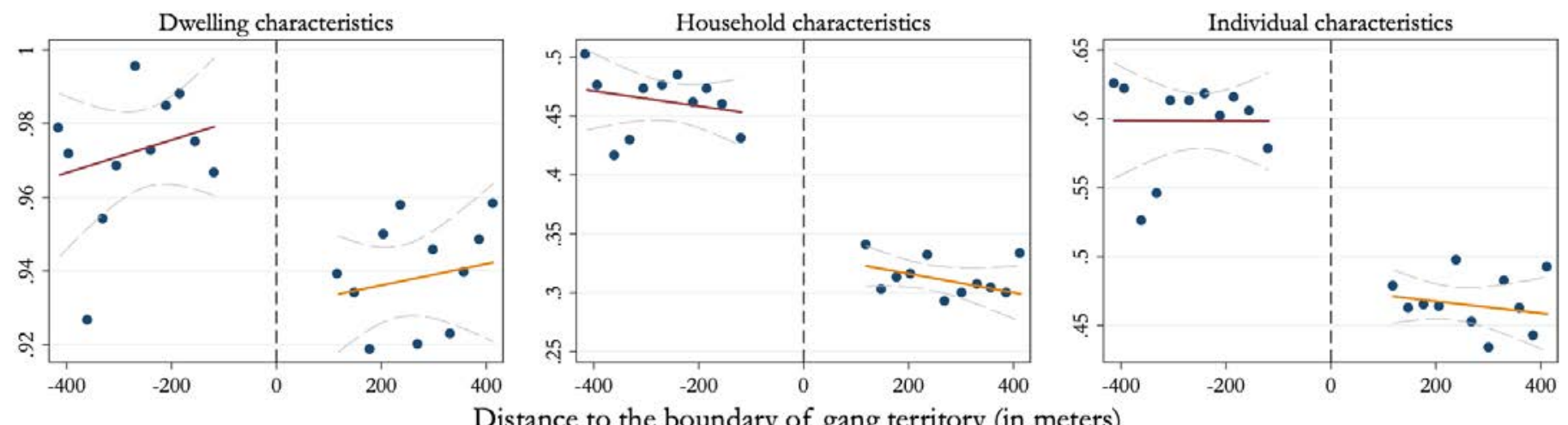

Distance to the boundary of gang territory (in meters)

- Mean of the outcome variable, by 30 meter bins
Linear prediction (outside of gang territory)

Note: The figure illustrates the regression discontinuity plots for the 1st principal components of the dwelling, household, and individual characteristics from the 2007 census after excluding observations within 100 meters of the boundary of gang territory. The unit of observation is a dwelling, a household, and an individual, depending on the specification. All the variables are normalized to vary between zero and one with higher values representing better outcomes. The vertical axis represents the average value of the outcomes variable; the horizontal axis-distance (in meters) to the boundary of gang territory. Neighborhoods to the left of the dashed line are located outside of gang territory; areas to the right are controlled by the gangs. The dots represent the average value of the outcome variable in that 30 meter bin. 
Figure A15: Alternative bandwidth: 60 meter bins

\section{1st principal component of the:}
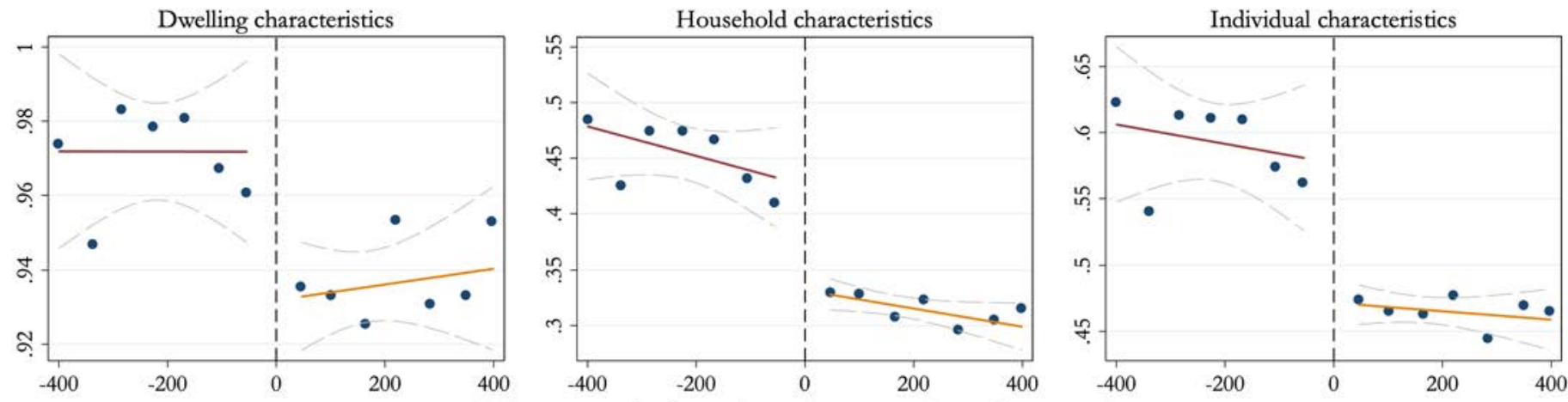

Distance to the boundary of gang territory (in meters)
- Mean of the outcome variable, by 60 meter bins
$95 \%$ confidence interval
Linear prediction (outside of gang territory) Linear prediction (gang territory)

Note: The figure illustrates the regression discontinuity plots for the 1st principal components of the dwelling, household, and individual characteristics from the 2007 census, using a larger bandwidth than in the baseline specification: the dots represent the average value of the outcome variable for 60 meter bins. The unit of observation is a dwelling, a household, and an individual, depending on the specification. All the variables are normalized to vary between zero and one with higher values representing better outcomes. The vertical axis represents the average value of the outcomes variable; the horizontal axis-distance (in meters) to the boundary of gang territory. Neighborhoods to the left of the dashed line are located outside of gang territory; areas to the right are controlled by the gangs. 
Figure A16: Alternative bandwidth: 20 meter bins

\section{1st principal component of the:}
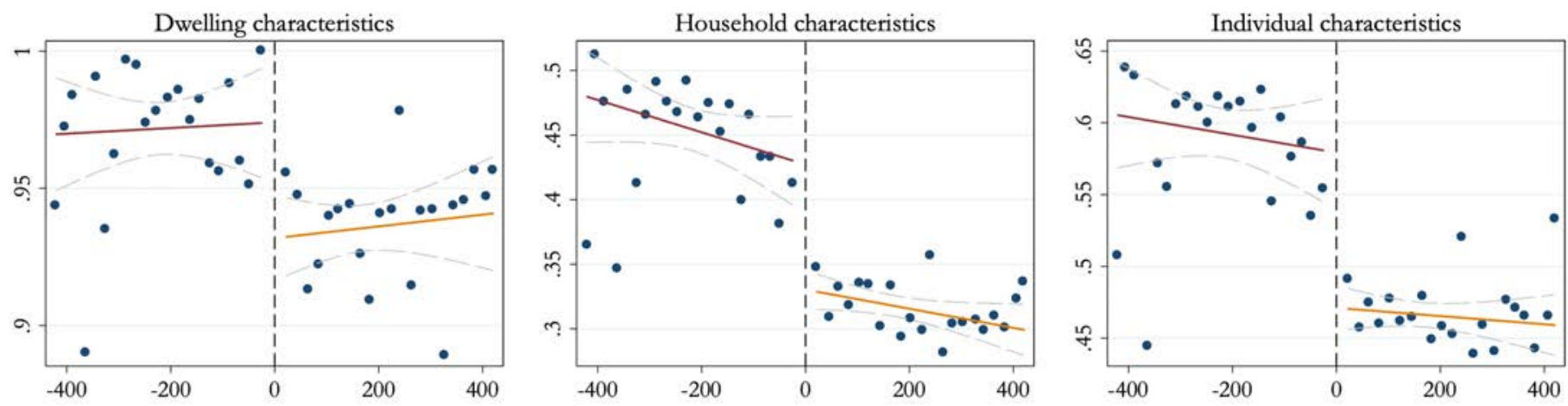

Distance to the boundary of gang territory (in meters)

- Mean of the outcome variable, by 20 meter bins $95 \%$ confidence interval Linear prediction (outside of gang territory) Linear prediction (gang territory)

Note: The figure illustrates the regression discontinuity plots for the 1st principal components of the dwelling, household, and individual characteristics from the 2007 census, using a narrower bandwidth than in the baseline specification: the dots represent the average value of the outcome variable for 20 meter bins. The unit of observation is a dwelling, a household, and an individual, depending on the specification. All the variables are normalized to vary between zero and one with higher values representing better outcomes. The vertical axis represents the average value of the outcomes variable; the horizontal axis-distance (in meters) to the boundary of gang territory. Neighborhoods to the left of the dashed line are located outside of gang territory; areas to the right are controlled by the gangs. 


\section{Figure A17: Housing rent}
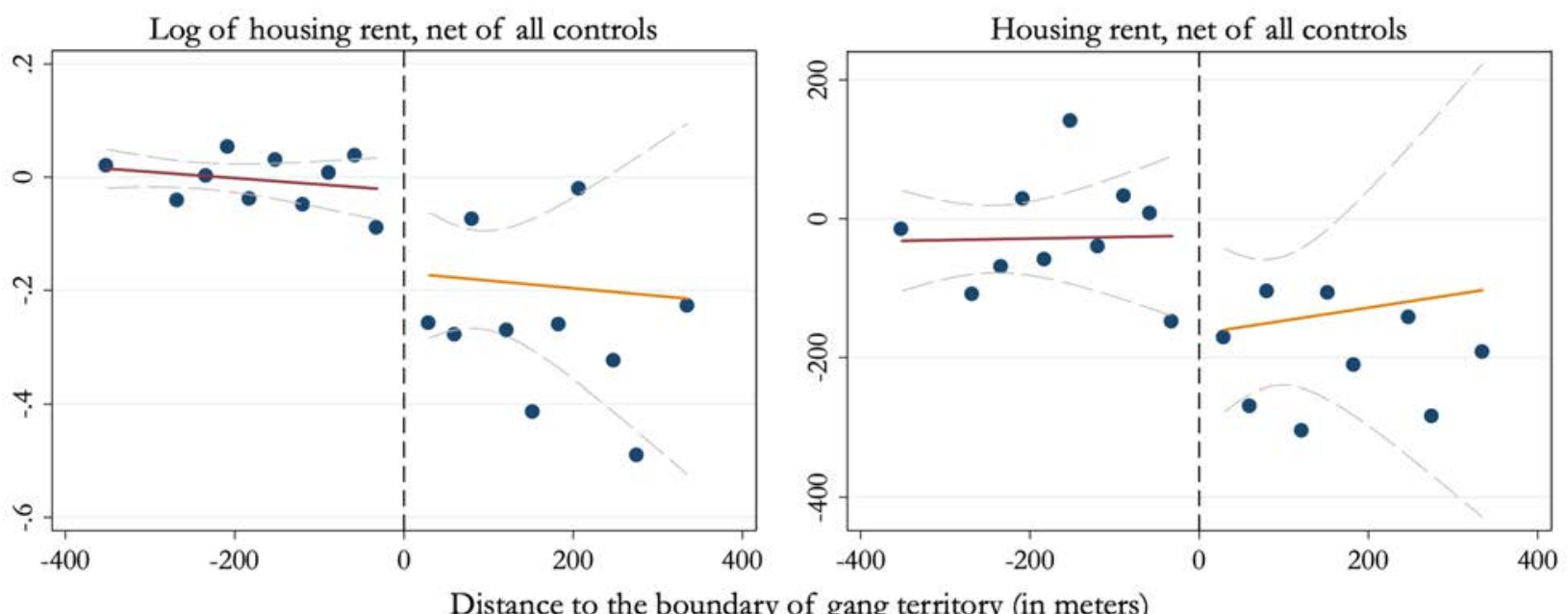

Distance to the boundary of gang territory (in meters)

- Mean of the outcome variable, by 30 meter bins

$95 \%$ confidence interval

Linear prediction (outside of gang territory) Linear prediction (gang territory)

Note: The figure illustrates the regression discontinuity plots for the residual of housing rent and log housing rent after subtracting the effects of all the control. The unit of observation is an apartment listing. The vertical axis represents the average value of the outcomes variable; the horizontal axis-distance (in meters) to the boundary of gang territory. Neighborhoods to the left of the dashed line are located outside of gang territory; areas to the right are controlled by the gangs. Omitted controls include dummies for the number of rooms, dummies for the number of bathrooms, a quadratic polynomial in square meters, a dummy for whether the apartment is being rented out by an agency rather than an individual, and a linear trend in distance to the boundary of gang territory, separately for locations on each side of the boundary. 
Figure A18: Availability of public goods
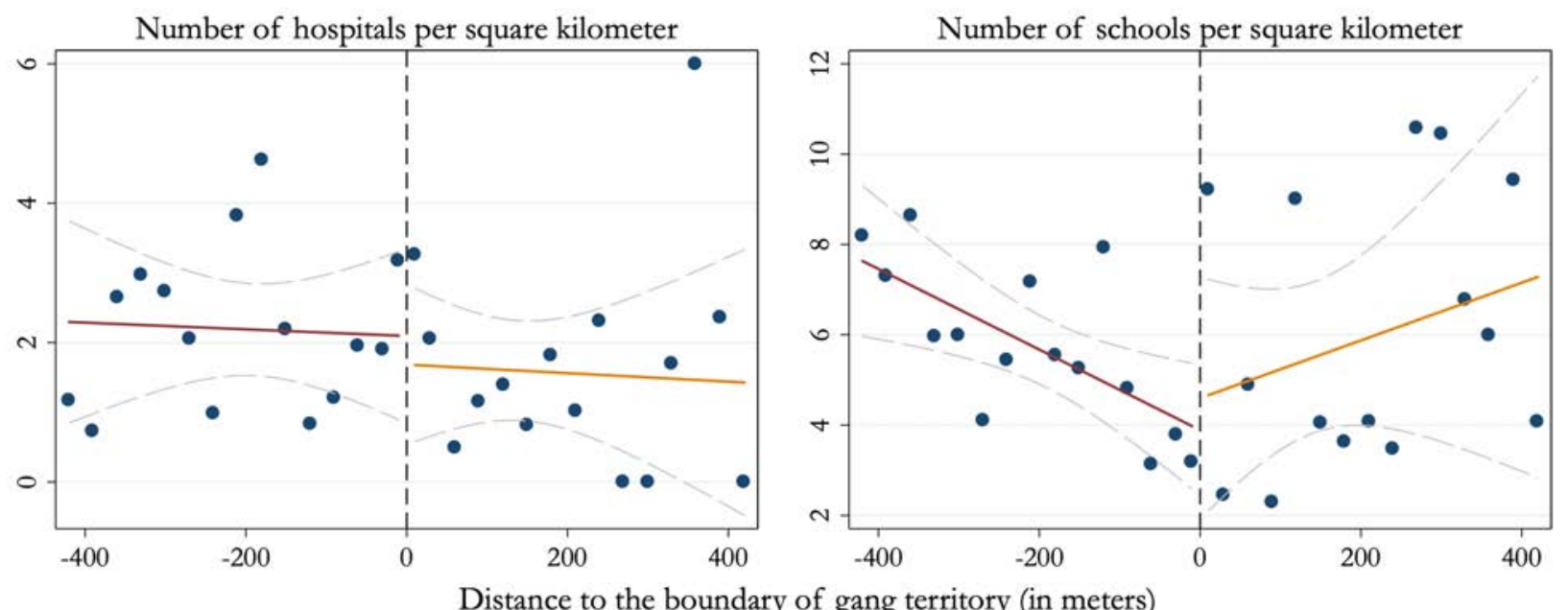

Distance to the boundary of gang territory (in meters)

- $\quad$ Mean of the outcome variable, by 30 meter bins

Linear prediction (outside of gang territory)
$95 \%$ confidence interval

Linear prediction (gang territory)

Note: The figure presents the regression discontinuity plots for the number of hospitals and schools per square kilometer. The unit of observation is a 10 meter bin, denoting distance to the boundary of gang territory. The vertical axis represents the average value of the outcomes variable; the horizontal axis - distance (in meters) to the boundary of gang territory. Neighborhoods to the left of the dashed line are located outside of gang territory; areas to the right are controlled by the gangs. The dots represent the average value of the outcome variable in that 30 meter bin. 
Figure A19: Satisfaction with the availability and quality of public goods

On a scale from 1 to 7 , satisfaction with the availability and quality of:

( 1 = extremely unsatisfied; 7 = extremely satisfied)
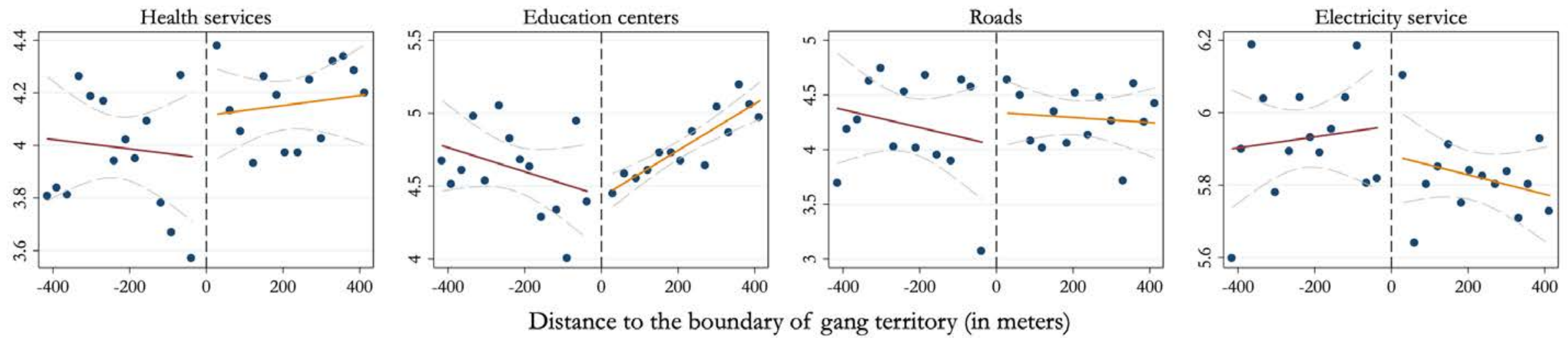

\begin{tabular}{lll|}
\hline Mean of the outcome variable, by 30 meter bins & $95 \%$ confidence interval \\
- & Linear prediction (outside of gang territory) & Linear prediction (gang territory) \\
\hline
\end{tabular}

Note: The figure presents the regression discontinuity plots for the questions about satisfaction with the availability and quality of public goods from the 2019 survey. The unit of observation is an individual. For all the questions, the respondents were asked to rate the availability and quality of public goods on a scale from 1 (extremely unsatisfied) to 7 (extremely satidfied). The vertical axis represents the average value of the outcomes variable; the horizontal axis-distance (in meters) to the boundary of gang territory. Neighborhoods to the left of the dashed line are located outside of gang territory; areas to the right are controlled by the gangs. The dots represent the average value of the outcome variable in that 30 meter bin. 
Figure A20: Grid squares, gang homicides in 2003-2004, and nighttime light density
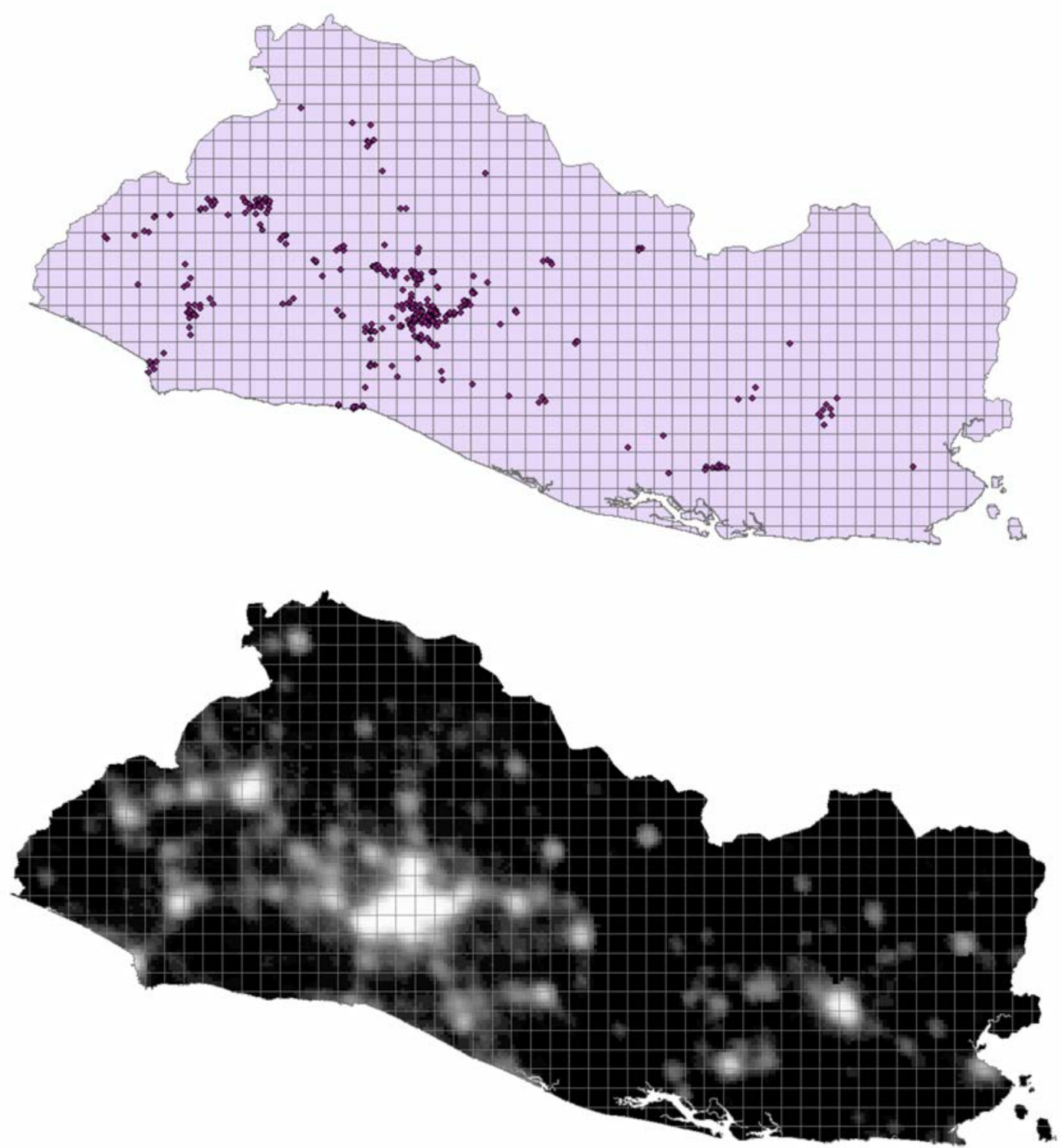

Note: The top part of the figure presents the locations of the gang-related homicides in 2003-2004. The bottom part of the figure presents the map of nighttime light density in 1995, one year before the change in the United States immigration policy. Both parts of the figure also present the boundaries of the grid cells used in the analysis. 
Figure A21: Grid squares, gang homicides in 2003-2004, and nighttime light density
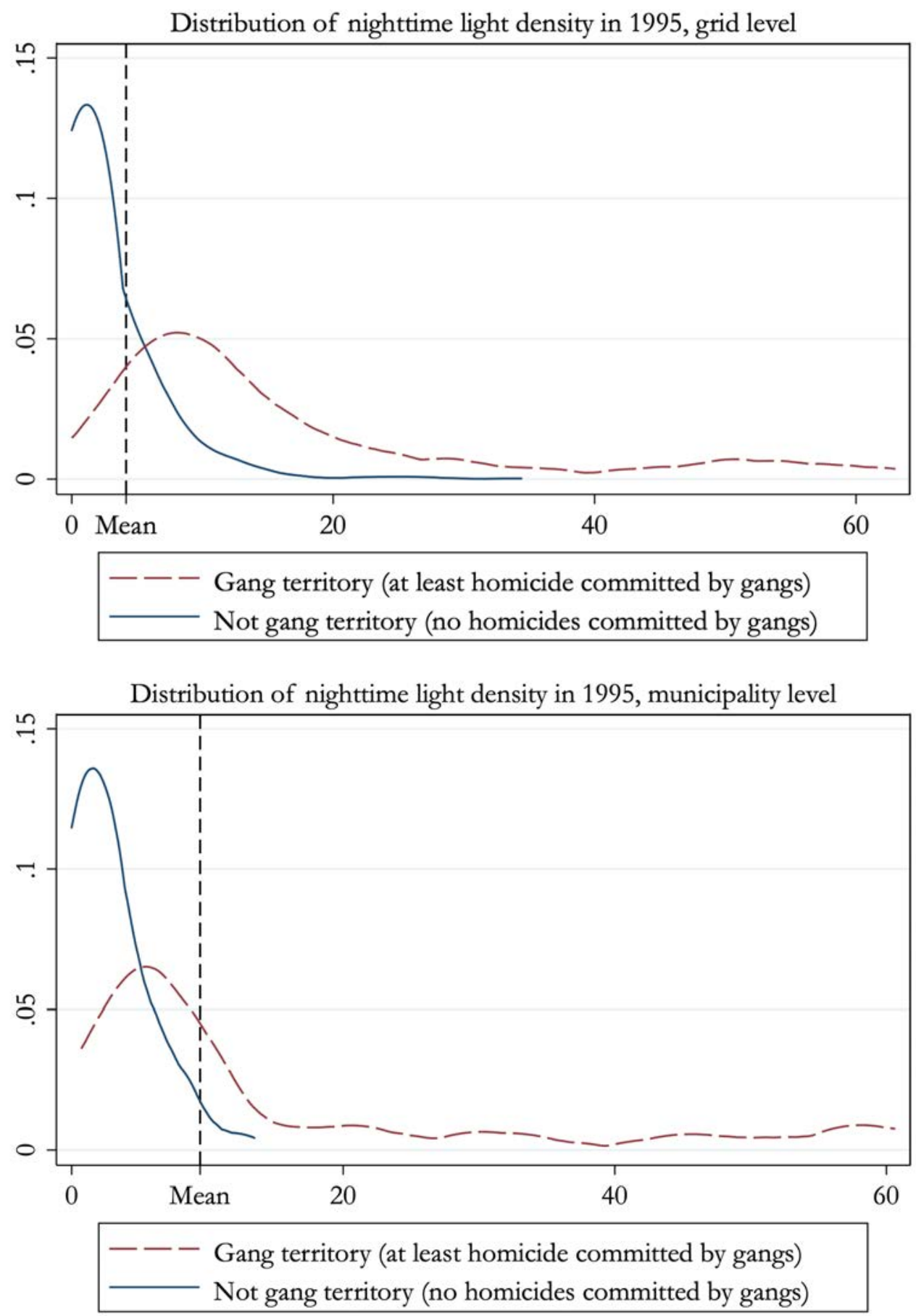
Figure A22: Gang-related homicides, by distance to the boundary of gang territory

\section{Panel A}

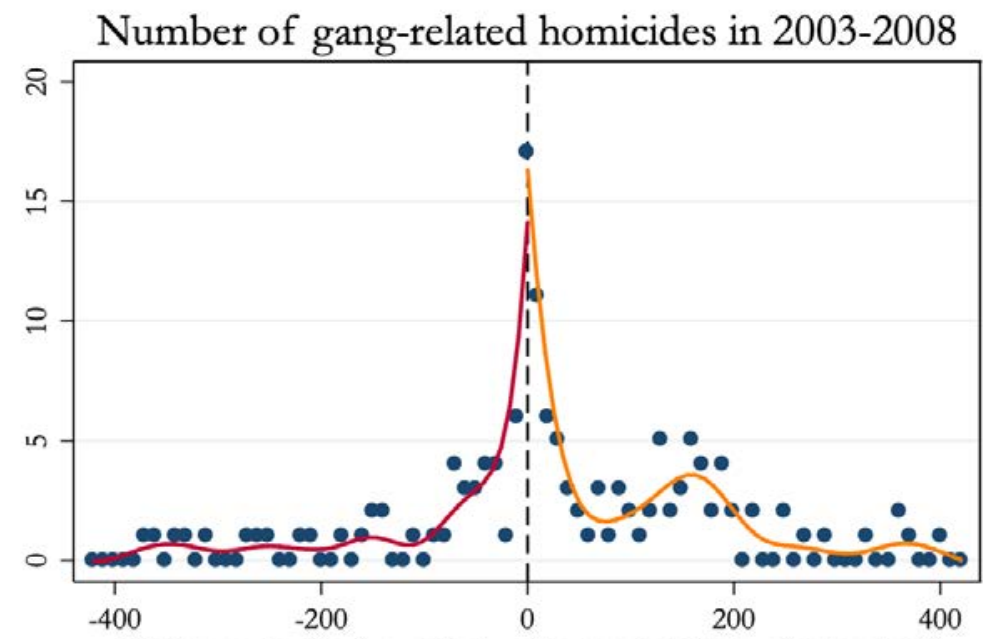

Distance to the boundary of gang territory (in meters)

- Mean of the outcome variable, by 10 meter bins

- Predicted value (lpoly), outside gang territory

Predicted value (lpoly), gang territory

\section{Panel B}

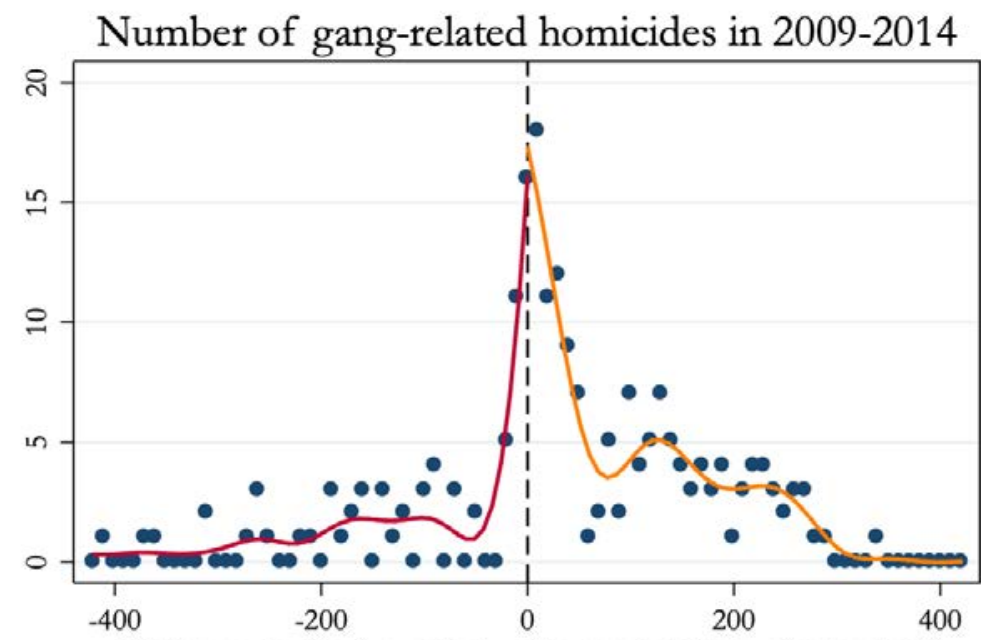

Distance to the boundary of gang territory (in meters)

- Mean of the outcome variable, by 10 meter bins

Predicted value (lpoly), outside gang territory

Predicted value (lpoly), gang territory

Note: The figure illustrates the number of gang-related homicides in 2003-2008 (Panel A) and 2009-2014 (Panel B), by distance to the boundary of gang territory. In both cases, the largest number of the homicides took place right at the boundary of gang territory. The vertical axis represents the average value of the outcomes variable; the horizontal axis-distance (in meters) to the boundary of gang territory. Neighborhoods to the left of the dashed line are located outside of gang territory; areas to the right are controlled by the gangs. The dots represent the average value of the outcome variable in that 10 meter bin. 